Aus dem Institut für Neuropathologie

(Prof. Dr. med. C. Stadelmann)

der Medizinischen Fakultät der Universität Göttingen

\title{
The effect of glatiramer acetate on functional properties of B lypmhocytes in patients with MS
}

\author{
INAUGURAL-DISSERTATION \\ zur Erlangung des Doktorgrades \\ der Medizinischen Fakultät der \\ Georg-August-Universität zu Göttingen
}

\author{
vorgelegt von \\ Zivar Hajiyeva \\ aus \\ Baku, Aserbaidschan
}

Göttingen 2021 
Dekan:

\section{Betreuungsausschuss}

Betreuer

Ko-Betreuer:

\section{Prüfungskommission}

Referent/in

Ko-Referent/in:

Drittreferent/in:

Datum der mündlichen Prüfung:
Prof. Dr. med. W.Brück

Prof. Dr. med. M. S. Weber

Prof. Dr. med. P. Huppke

Prof. Dr. med. M. S. Weber 
Hiermit erkläre ich, die Dissertation mit dem Titel "The effect of glatiramer acetate on functional properties of B lymphocytes in patients with MS" eigenständig angefertigt und keine anderen als die von mir angegebenen Quellen und Hilfsmittel verwendet zu haben.

Göttingen, den 
Die Ergebnisse dieser Arbeit wurden teilweise veröffentlicht:

Häusler D, Hajiyeva Z, Traub JW, Zamvil SS, Lalive PH, Brück W, Weber MS. Glatiramer acetate immune modulates B-cell antigen presentation in treatment of MS. Neurol Neuroimmunol Neuroinflamm. 7(3), e698. 
Table of contents

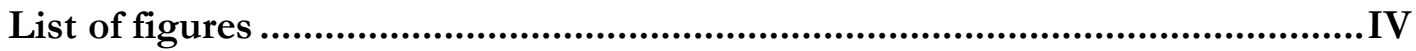

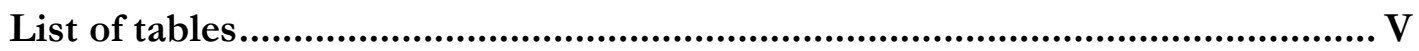

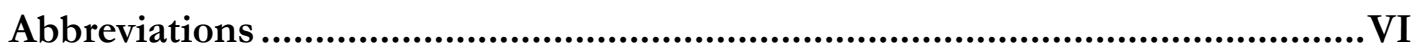

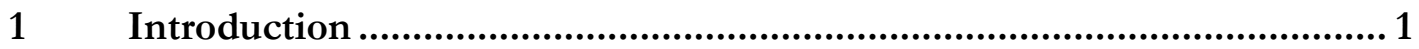

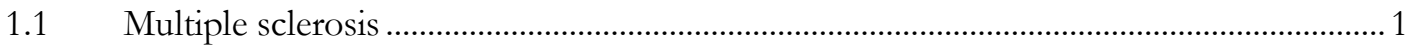

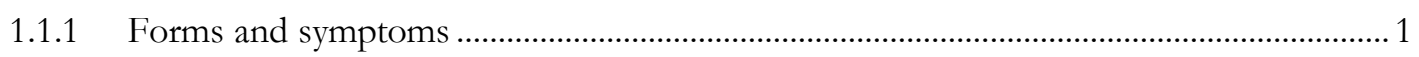

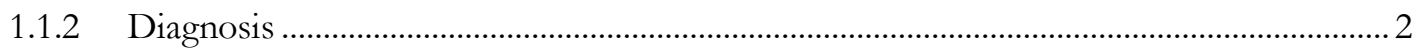

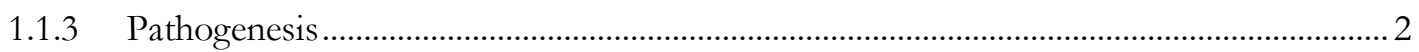

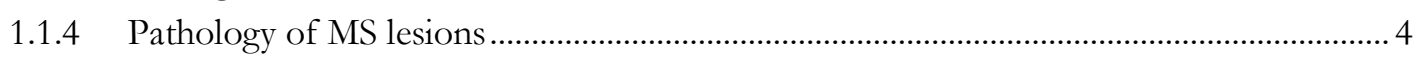

1.1.5 B cells in multiple sclerosis ........................................................................................ 5

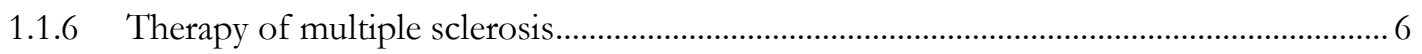

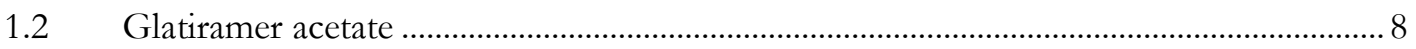

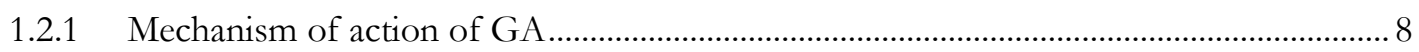

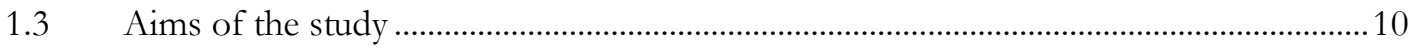

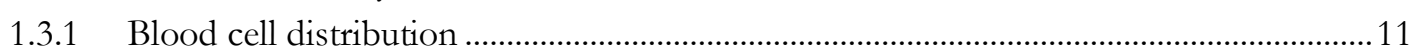

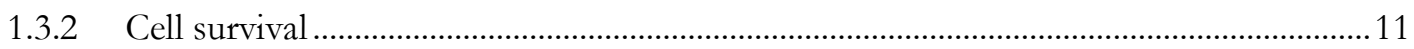

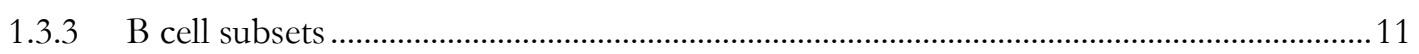

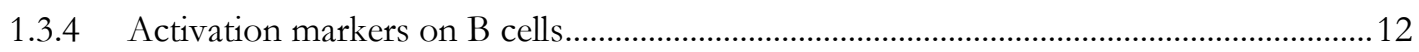

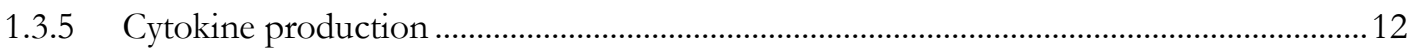

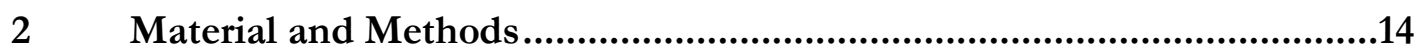

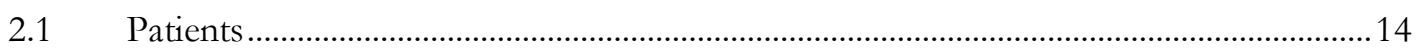

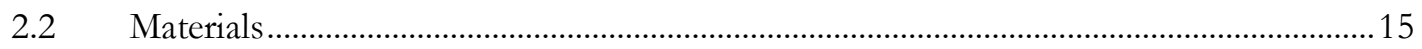

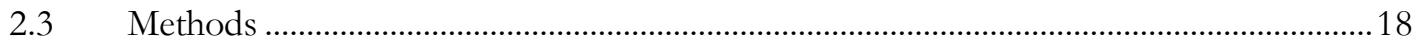

2.3.1 Preparation of human peripheral blood mononuclear cells (PBMC) ………...................18

2.3.2 FACS (fluorescence-activated cell sorting) panels and stimulation regime .....................19

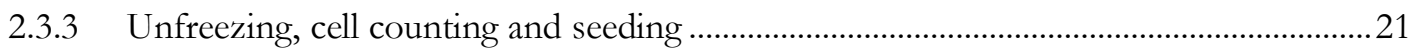

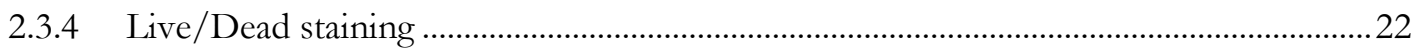

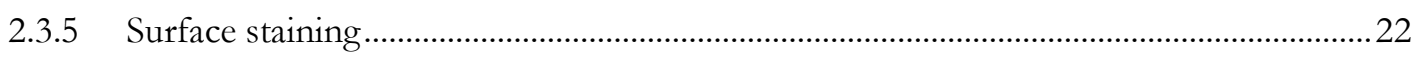

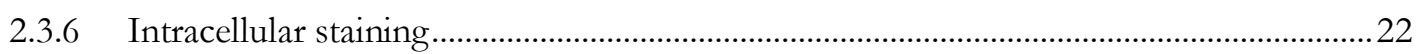

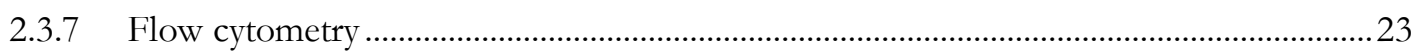

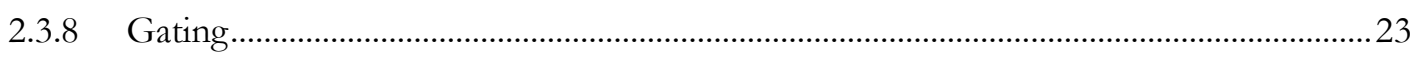

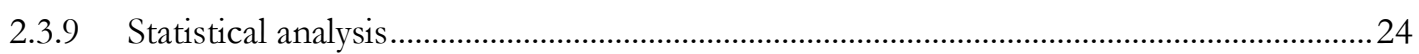

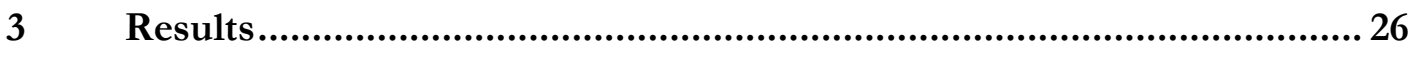

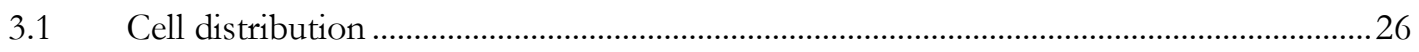

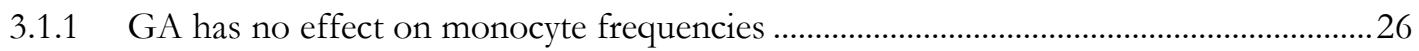

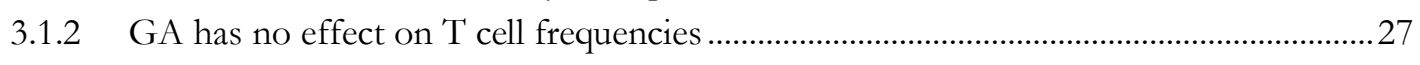

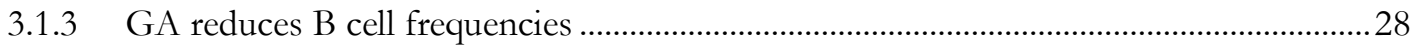

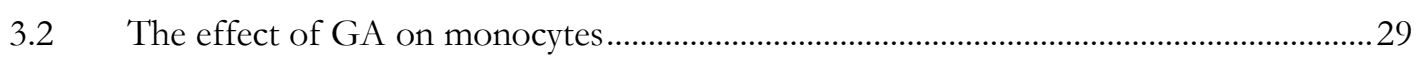

3.2.1 GA has no effect on the expression of CD150 on monocytes......................................29 
3.2.2 GA has no effect on the MHC II expression on monocytes .............................................30

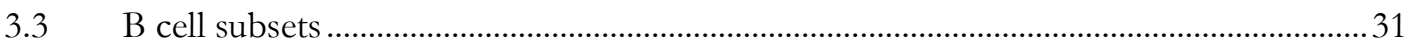

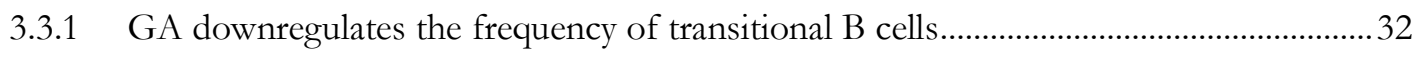

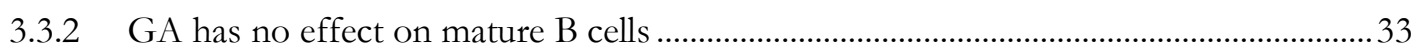

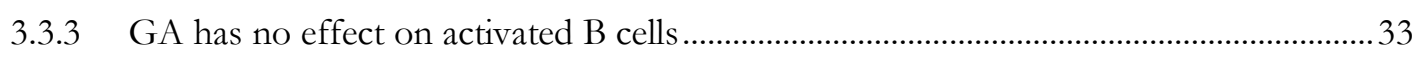

3.3.4 GA treatment has no effect on memory B cell frequency................................................ 34

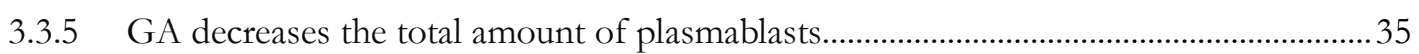

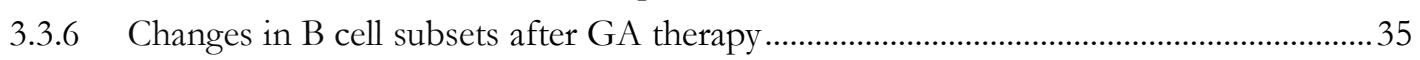

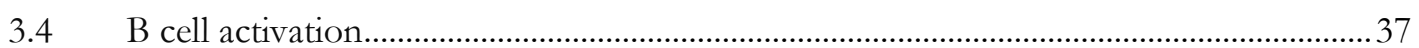

3.4.1 GA reduces the expression of CD25 on stimulated B cells .............................................. 37

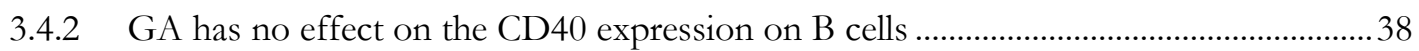

3.4.3 GA reduces the expression of CD69 on stimulated B cells ................................................ 38

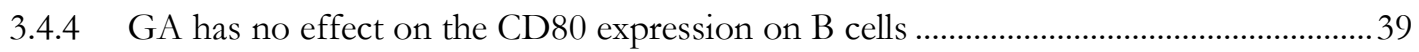

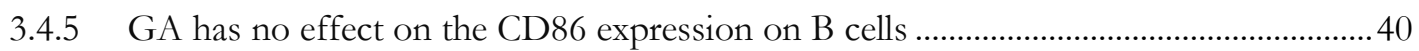

3.4.6 The expression of CD95 on B cells positively correlates with GA treatment duration 41

3.4.7 GA upregulates the expression of MHC II on B cells .................................................... 43

3.4.8 Summary of the GA-induced activation marker changes on B cells ................................43

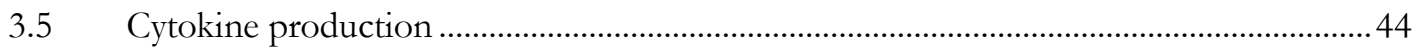

3.5.1 GA has no effect on the IL-6 production in B cells......................................................... 45

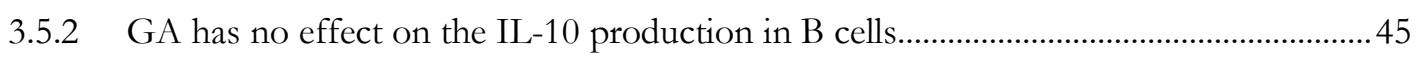

3.5.3 GA downregulates the TNF- $\alpha$ production in B cells ...................................................... 46

3.5.4 Summary of the cytokine production upon GA therapy .................................................... 47

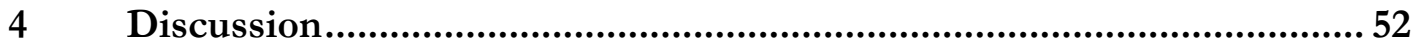

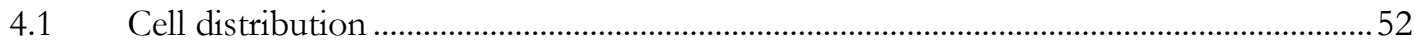

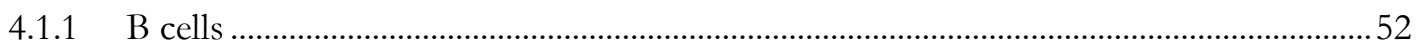

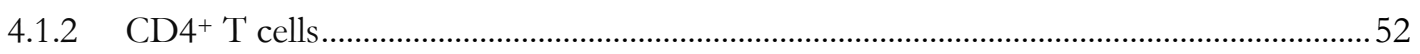

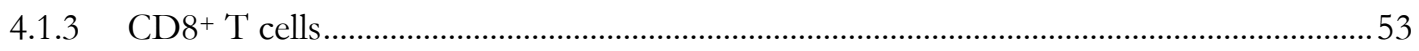

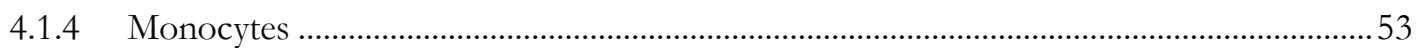

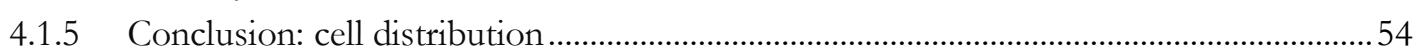

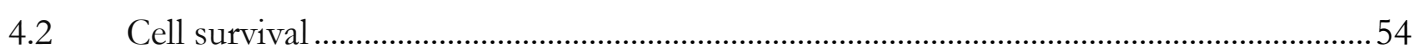

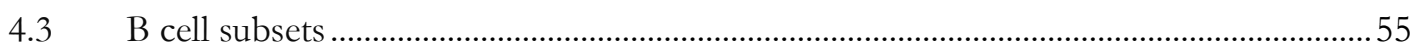

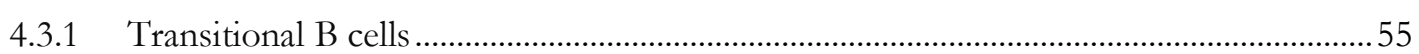

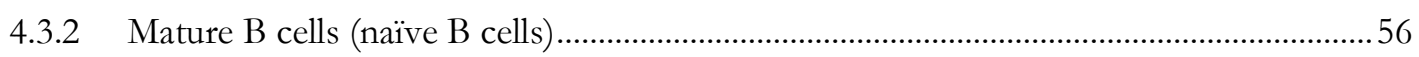

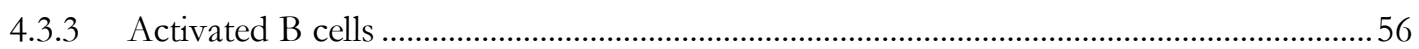

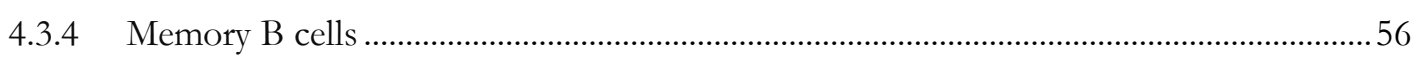

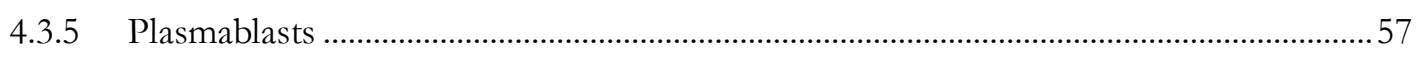

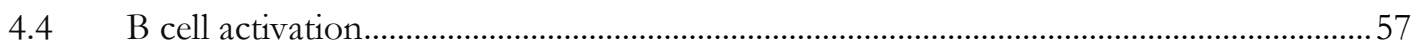

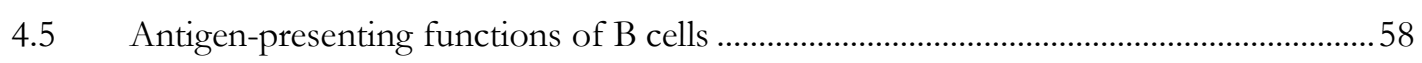

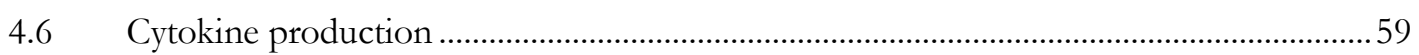

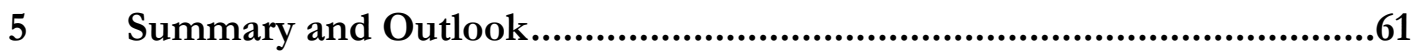

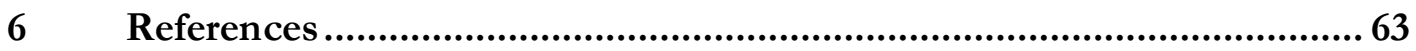

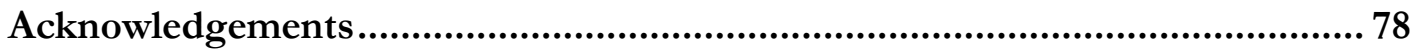


Curriculum Vitae 


\section{List of figures}

Figure 1: Pre-gating and gating strategy for B cell subsets and surface molecule expression...24

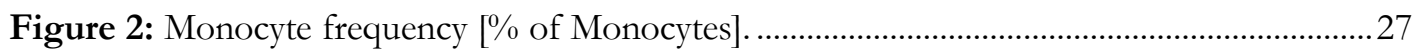

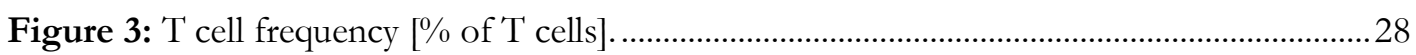

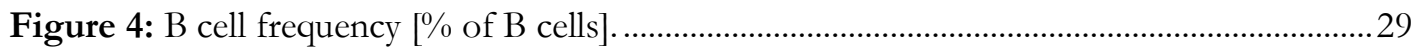

Figure 5: CD150+ Monocytes [\% of Monocytes].................................................................... 30

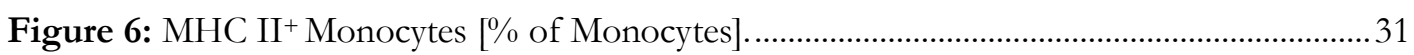

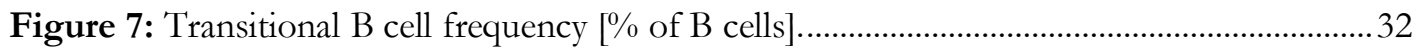

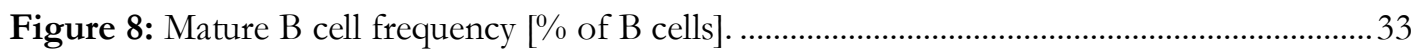

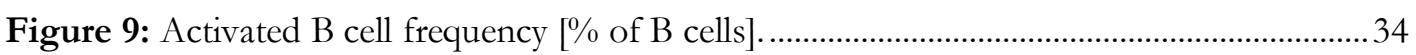

Figure 10: Memory B cell frequency [\% of B cells]..................................................................... 34

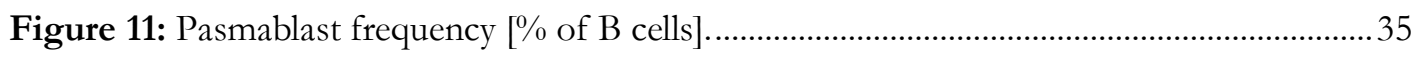

Figure 12: Changes in the $\mathrm{B}$ cell subsets after GA therapy. ........................................................... 36

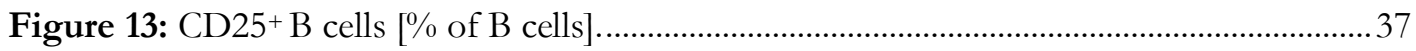

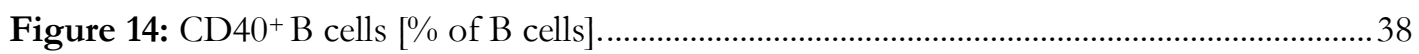

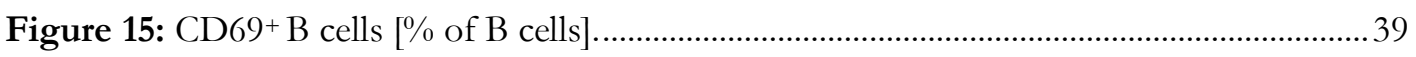

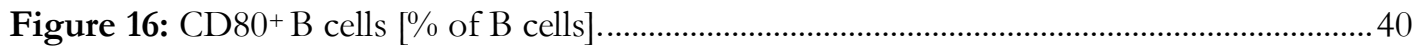

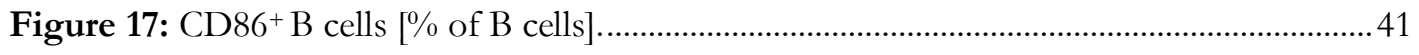

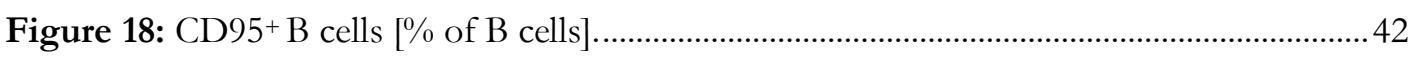

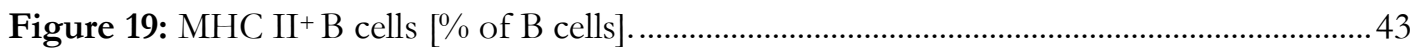

Figure 20: Changes in the expression of activation markers on B cells after GA therapy........ 44

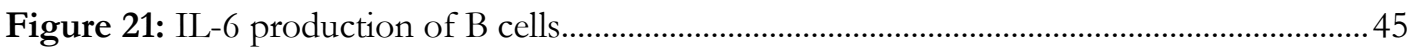

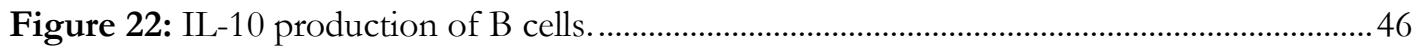

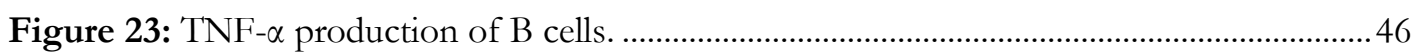

Figure 24: Changes in the B cell cytokine production after GA therapy.................................... 48 


\section{List of tables}

Table 1: McDonald criteria (Thompson et al. 2018) ....................................................................2

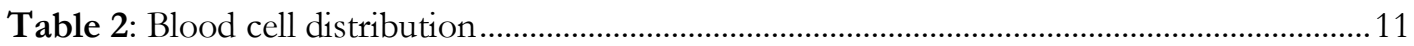

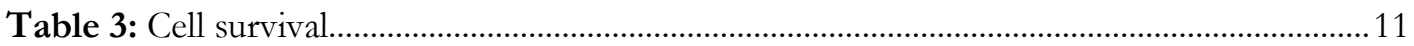

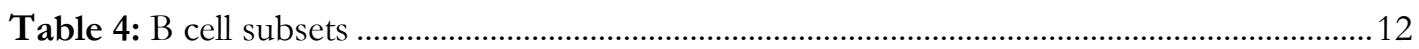

Table 5: The disease and demographic characteristics of the patients ...................................... 14

Table 6: Human monoclonal antibodies for flow cytometry .................................................... 15

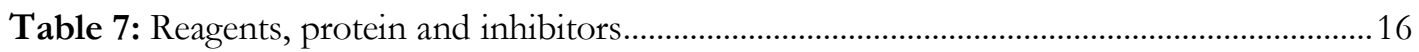

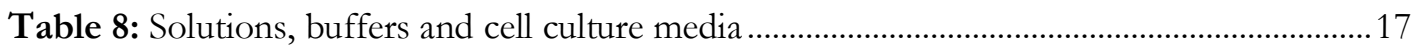

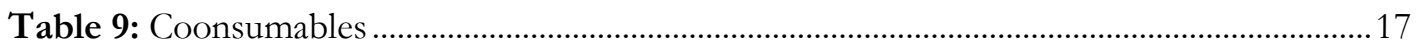

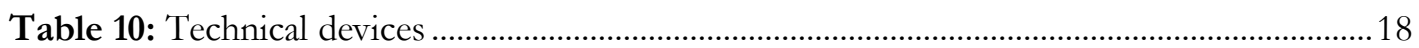

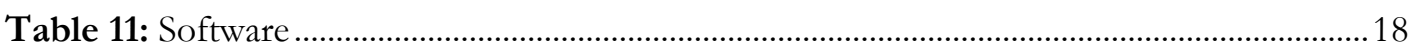

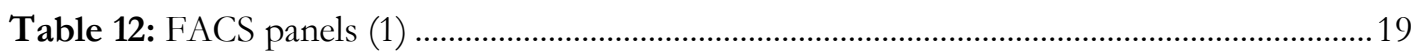

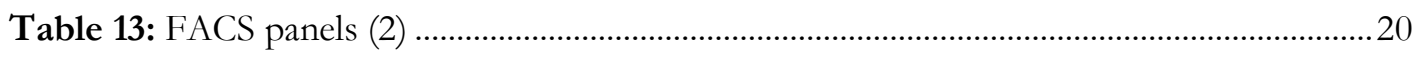

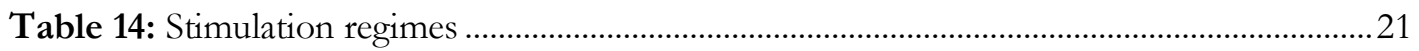

Table 15: Correlation between cell distribution and therapy duration ......................................48

Table 16: Correlation between B cell subsets and GA therapy duration ..................................49

Table 17: Correlation between cell surface markers and GA therapy duration ..........................50

Table 18: Correlation between cytokine production and GA therapy duration..........................5 51 


\section{Abbreviations}

\begin{tabular}{|c|c|}
\hline APC & Antigen-presenting cell \\
\hline APRIL & A proliferation-inducing ligand \\
\hline BAFF & $\mathrm{B}$ cell activation factor \\
\hline BBB & Blood brain barrier \\
\hline BCR & B cell receptor \\
\hline BSA & Bovine serum albumin \\
\hline CIS & Clinically isolated syndrome \\
\hline CNS & Central nervous system \\
\hline CpG & Cytosine-phosphate-Guanine \\
\hline CSF & Cerebrospinal fluid \\
\hline DC & Dendritic cell \\
\hline dil. fac. & Dilution factor \\
\hline DIS & Dissemination in space \\
\hline DIT & Dissemination in time \\
\hline DMEM & Dulbecco's Modified Eagle's Medium \\
\hline DMF & Dimethyl fumarate \\
\hline DMT & Disease-modifying therapy \\
\hline DMSO & Dimethyl Sulfoxide \\
\hline EAE & Experimental autoimmune encephalomyelitis \\
\hline EBV & Epstein-Barr virus \\
\hline ED & Encephalitis disseminate \\
\hline EDSS & Expanded disability status scale \\
\hline EDTA & Ethylene diamine tetraacedic acid disodium salt dihydrate \\
\hline ELISA & Enzyme-linked immunosorbent assay \\
\hline FACS & Fluorescence-activated cell sorting \\
\hline FCS & Fetal calf serum \\
\hline FDA & US Food and Drug Administration \\
\hline
\end{tabular}




\begin{tabular}{|c|c|}
\hline FSC & Forward scatter \\
\hline GA & Glatiramer acetate \\
\hline GM-CSF & Granulocyte-macrophage colony stimulating factor \\
\hline HHV-6 & Human herpesvirus 6 \\
\hline HLA-DR & Human leukocyte antigen - antigen D related \\
\hline i.m. & Intramuscular \\
\hline IFN $\beta$ & Interferon beta \\
\hline IgG & Immunoglobulin $G$ \\
\hline IL-4 & Interleukin 4 \\
\hline IL-5 & Interleukin 5 \\
\hline IL-6 & Interleukin 6 \\
\hline IL-10 & Interleukin 10 \\
\hline IL-35 & Interleukin 35 \\
\hline INF $\gamma$ & Interferon gamma \\
\hline int & Intermediate \\
\hline ITP & Idiopathic thrombocytopenic purpura \\
\hline JC virus & John Cunningham virus \\
\hline LPS & Lipopolysaccharide \\
\hline $\mathbf{L T}-\alpha$ & Lympotoxin-alpha \\
\hline MBP & Myelin basic protein \\
\hline MFI & Mean fluorescence intensity \\
\hline MHC-II & Major histocompatibility complex-class II \\
\hline MOG & Myelin oligodendrocyte glycoprotein \\
\hline MRI & Magnetic resonance imaging \\
\hline MS & Multiple Sclerosis \\
\hline NAWM & Normal appearing white matter \\
\hline NEDA & No evidence of disease activity \\
\hline NK cell & Natural killer cell \\
\hline
\end{tabular}




\begin{tabular}{|c|c|}
\hline NMSS & National multiple sclerosis society (US) \\
\hline N.s. & Not significant \\
\hline NT3 & Neurotrophin-3 \\
\hline PBMC & Peripheral blood mononuclear cells \\
\hline p.o. & Peros \\
\hline PBS & Phosphate-buffered salt solution \\
\hline PFA & Para-formaldehyde \\
\hline PKC & Protein kinase $\mathrm{C}$ \\
\hline PLP & Proteolipid protein \\
\hline PMA & Phorbol 12-myristate 13 -acetate \\
\hline PML & Progressive multifocal leukoencephalopathy \\
\hline PPMS & Primary progressive multiple sclerosis \\
\hline PRMS & Progressive relapsing multiple sclerosis \\
\hline $\mathbf{R}$ & Pearsons correlation coefficient \\
\hline $\mathbf{R}^{2}$ & Coefficient of determination \\
\hline RIS & Radiologically isolated syndrome \\
\hline Rpm & Revolutions per minute \\
\hline RPMI-1640 & Roswell Park Memorial Institute-1640 \\
\hline RRMS & Relapsing-remitting multiple sclerosis \\
\hline s.c. & Subcutaneous \\
\hline SD & Standard deviation \\
\hline SEM & Standard error of the mean \\
\hline SIP & Sphingosine-1-phosphate \\
\hline SLAM & Signaling lymphocytic activation molecule \\
\hline SPMS & Secondary progressive multiple sclerosis \\
\hline SSC & Side scatter \\
\hline TERI & Teriflunomid \\
\hline Th cell & $\mathrm{T}$ helper cell \\
\hline
\end{tabular}




\begin{tabular}{|l|l|}
\hline TLR & Toll-like receptor \\
\hline TMB & Tetramethylbenzidine \\
\hline TNF- $\alpha$ & Tumor necrosis factor alpha \\
\hline
\end{tabular}




\section{Introduction}

\subsection{Multiple sclerosis}

Multiple sclerosis (MS) is the most common immune-mediated disorder, which affects the central nervous system and leads to damage of myelin and axons (Compston und Coles 2008). It is also known that a loss of brain volume occurs in most patients throughout the MS course (De Stefano et al. 2015). The patients develop cognitive, neurological and psychological disabilities (Ghasemi 2017). The exact etiology of MS is still unknown. Multiple studies suggest that a combination of environmental, infectious and genetic factors may play a role in MS (Compston and Coles 2002).

\subsubsection{Forms and symptoms}

MS may cause any neurological symptom. The most common symptoms are visual, motor and sensory signs. Tornes and colleagues (Tornes et al. 2014) described such symptoms as nystagmus, tremor, dysmetria, truncal ataxia and dysdiadochokinesia in MS patients with cerebellar lesions. Rare manifestations such as cranial nerve involvement, pain syndromes, psychiatric or cognitive symptoms are also possible (Evlice et al. 2016).

There are different phenotypes of progression in MS, which were first described by Lublin and Reingold (Lublin and Reingold 1996). In 1996, the US National Multiple Sclerosis society (NMSS) distinguished four forms of MS clinical courses: relapsing-remitting (RR), secondary progressive (SP), primary progressive (PP) and progressive-relapsing (PR).

Depending on the phenotype of progression in MS, the prognosis and treatment options may change. Each phenotype is characterized by progression or relapses. Relapses in MS are defined as transient neurological dysfunctions, which cannot be explained through other clinical conditions than MS activity and last for at least $24 \mathrm{~h}$ (Kamm et al. 2014). The disease activity or progression is measured by expanded disability status score (EDSS score) (Kurtzke 2015). The RRMS is characterized by relapses, which are followed by periods with no disease activity (Tsang and Macdonell 2011). There is an initial form of RRMS, called clinically isolated syndrome (CIS). Patients with CIS display MS symptoms, but do not fulfill the diagnostic criteria of multiple sclerosis (Compston and Coles 2002). Approximately 30-70\% of those patients afterwards develop a RRMS disease course (Miller et al. 2005). Clinical trials have shown that around $65 \%$ of the initial RRMS phenotype turns into SPMS disease course. SPMS is a phenotype characterized by progressive clinical disability between relapses and acute attacks, without defined periods of remission (Compston and Coles 2008; Lublin and Reingold 1996). Approximately $10-15 \%$ of MS patients show progressive disability after disease onset. This group of patients has PPMS. PPMS is characterized by late onset and progressive clinical worsening, which takes months to years (Miller and Leary 2007). 
Devic's neuromyelitis optica, Marburg's acute MS, Balo's concentric sclerosis, and Schilder's diffuse sclerosis are atypical forms of MS (Stadelmann and Brück 2004).

\subsubsection{Diagnosis}

A combination of clinical evaluation, radiological and laboratory data makes it possible to diagnose MS. Many criteria have been used in the past. The latest ones are the McDonald criteria. The first description of the McDonald criteria was in 2001. In the following years, they were reviewed three times (McDonald et al. 2001; Polman et al. 2005; Polman et al. 2011; Thompson et al. 2018) and are all based on clinical, radiological and laboratory findings at varying locations and times. The latest review of the McDonald criteria from 2017 (Thompson et al. 2018) suggests that the presence of CSF-specific oligoclonal bands demonstrates dissemination in time and allows, together with MRI findings, to diagnose MS at very early stages of the disease.

Table 1: McDonald criteria (Thompson et al. 2018)

\begin{tabular}{|c|c|}
\hline Clinical presentation & Additional data needed \\
\hline $\begin{array}{l}\geq 2 \text { clinical attacks (relapses) and } \\
\text { objective clinical evidence of } \geq 2 \\
\text { lesions }\end{array}$ & None \\
\hline $\begin{array}{l}\geq 2 \text { clinical attacks (relapses) and } \\
\text { objective clinical evidence of } 1 \text { lesion }\end{array}$ & $\begin{array}{l}\text { Dissemination in space, demonstrated by: } \\
\text { an additional clinical attack, implicating a different CNS } \\
\text { side or MRI }\end{array}$ \\
\hline $\begin{array}{l}1 \text { clinical attack (relapse) and objective } \\
\text { clinical evidence of } 2 \text { lesions }\end{array}$ & $\begin{array}{l}\text { Dissemination in time, demonstrated by: } \\
\text { an additional clinical attack or MRI or CSF specific } \\
\text { oligoclonal bands }\end{array}$ \\
\hline $\begin{array}{l}1 \text { clinical relapse and objective clinical } \\
\text { evidence of } 1 \text { lesion }\end{array}$ & $\begin{array}{l}\text { Dissemination in space, demonstrated by: } \\
\text { an additional clinical attack implicating a different CNS } \\
\text { side or MRI } \\
\text { Dissemination in time, demonstrated by: } \\
\text { an additional clinical attack or MRI or CSF specific } \\
\text { oligoclonal bands }\end{array}$ \\
\hline
\end{tabular}

\subsubsection{Pathogenesis}

It is evident that the immune system plays a central role in MS. Studies suggest that microglia and macrophages are the immune cells that play a dominant role in the pathogenesis of MS. 
Due to histopathological investigations, the mononuclear phagocytes, including microglia and macrophages, are the dominant immune cells in MS lesions (Hemmer et al. 2015). Investigations on animal models of experimental autoimmune encephalomyelitis (EAE) suggest that phagocytes contribute to both demyelination and remyelination (Shechter et al. 2013).

Several lines of evidence indicate that the adaptive immune system plays an important role in the immunology of MS. There are two major hypotheses in MS pathology during the early inflammatory phase (Hemmer et al. 2015).

The first one suggests that the initiating event occurs first in the central nervous system (CNS), causing the activation of microglia, which subsequently results in secondary recruitment of adaptive and innate immune cells. In 2009, Henderson and colleagues showed that there were no $\mathrm{T}$ or $\mathrm{B}$ cells in areas of initial oligodendrocyte loss, but rather phagocytes with incorporated myelin proteins. In contrast, the areas of complete demyelination were filled with B and T cells as well as IgG-positive plasma cells (Henderson et al. 2009).

The second hypothesis suggests that the antigen-specific immune activation occurs first in the periphery. Then, the activated immune cells cross the blood brain barrier (BBB) and transmigrate into the CNS. The experiments in EAE showed that transferred encephalitogenic T cells were first found in cervical lymph nodes followed by infiltration and reactivation within the CNS (Lassmann 2013; Sospedra and Martin 2005).

It has been considered that MS is a T cell-mediated autoimmune disease. Investigations showing the possibility to induce EAE by transferring encephalitogenic $\mathrm{T}$ cells in naïve animals support this consideration (Constantinescu and Gran 2014). CD4 ${ }^{+} \mathrm{T}$ cells were mostly found in acute lesions, while $\mathrm{CD}^{+} \mathrm{T}$ cells were predominantly present in chronic lesions. "Molecular mimicry" is the most popular theory of the pathogenesis of MS. According to this theory, the $\mathrm{CD}^{+}{ }^{+} \mathrm{T}$ cells are activated by foreign antigen and cross-react with myelin antigens. Zhang and Raus (Zhang and Raus 1994) showed that activated myelinreactive $\mathrm{CD}^{+} \mathrm{T}$ cells were found in both blood and CSF of MS patients; in contrast, nonactive $\mathrm{CD}^{+}{ }^{+} \mathrm{T}$ cells were found only in blood of controls. The most accepted theory suggests that myelin-specific $\mathrm{CD} 4^{+} \mathrm{T}$ cells could be activated by certain antigens that show a molecular mimicry to CNS components. There are several examples showing the crossreactivity of $\mathrm{CD}^{+} \mathrm{T}$ cells with a myelin basic protein (MBP) such as Epstein-Barr virus (EBV), human herpesvirus 6 (HHV-6), coronavirus (Chitnis 2007).

Several lines of evidence demonstrate also an important role for B- and plasma cells in the pathogenesis of MS, which will be discussed in more detail in chapter 1.1.5.

Immunological mechanisms during the progressive phase of MS are also unclear. Researchers discuss actually two possible mechanisms called "Inside-Out" and "OutsideIn". 
Investigators believing in the Outside-In model, suggest that the primary target in MS is myelin (outside) and that the axonal (inside) lesions occur secondary (Henderson et al. 2009). Myelin/Oligodendrocytes may be damaged by virus infections, macrophages, cytotoxic $\mathrm{T}$ cells and autoantibodies etc.

The Inside-Out theory suggests that the initial damage occurs in axons, triggering a secondary demyelination. Investigations on spinal cord sections showed that axonal damage may lead to oligodendrocyte apoptosis, causing a demyelination (Tsunoda and Fujinami 2002).

\subsubsection{Pathology of MS lesions}

There are three major effects, which can be seen in MS lesions: myelin loss or demyelination, axonal damage or neurodegeneration, and proliferation of astrocytes, which leads to gliosis. Additionally, in the early stages of the disease, a process of remyelination takes place (Lassmann 2013). MS has always been considered to be a white matter disease, but recent investigations also show demyelinated lesions in the cortical grey matter and normalappearing white matter (NAWM) (Frischer et al. 2009).

White matter lesions are frequently observed in MS. There are different types of white matter lesions: slowly expanding lesions, classical active lesions, inactivated lesions and remyelinated shadow plaques. Active lesions contain lymphocytic inflammation and massive macrophage infiltration. The progressive stage of MS is characterized by slowly expanded lesions with an inactive core surrounded by infiltrations of macrophages and activated glia. Lesions without microglia activation and macrophage activity are called inactive plaques. Their number increases with the age of patients and disease duration (Lassmann 2013). It was also described that sometimes oligodendrocytes may reappear within the active lesions in the early stages of MS. As a result completely remyelinated plaques, the so-called shadow plaques may appear (Patrikios et al. 2006).

Cortical lesions were described in all stages of MS; however, they are present more frequently in the progressive stage. There are three types of cortical lesions: cortico-subcortical, intracortical and subpial lesions (Lassmann 2008). All types of cortical lesions were associated with active inflammation by $\mathrm{T}$-cell infiltrates on the early stages of the disease. However, meningeal inflammation was described in cortical lesions in the progressive stage of MS (Fischer et al. 2013). In 2008, Moll and colleagues compared cortical lesions in progressive multifocal leukoencephalopathy (PML) and MS and concluded that subpial cortical lesions were highly specific for multiple sclerosis pathology (Moll et al. 2008).

In the progressive stage of MS new inflammatory lesions in the white matter are rare, but several changes in NAWM were described. It has been considered that these changes occur due to diffuse axonal injury, which leads to Wallerian degeneration (Kutzelnigg et al. 2005). 
Lucchinetti and colleagues suggested that the mechanisms of demyelination may differ between MS patients and classified the MS lesions into four patterns (Lucchinetti et al. 2000; Popescu et al. 2013):

The Pattern I was found in approximately $15 \%$ of biopsied MS patients and characterized by $\mathrm{T}$ cell and macrophage activation as well as infiltration with active demyelination. However, a high incidence of remyelination could also be noticed.

Pattern II is the most common pattern of MS lesions. This type of lesions is similar to the pattern I with the additional presence of plasma cells and complement deposits.

Pattern III is characterized by the apoptosis of oligodendrocytes and weak T cell infiltrations. There is no evidence of the presence of complement deposits or plasma cells in this type of lesions.

Pattern IV is the rarest type of MS lesions and considered to occur due to metabolic oligodendrocyte injury. In these lesions, primary degeneration of oligodendrocytes plays an important role.

\subsubsection{B cells in multiple sclerosis}

Although MS has historically been considered to be a T cell-associated autoimmune disease, investigations of recent years suggest that there is an important role of B cells in the pathogenesis of MS. There are three major roles of B cells: antibody production, antigen presentation and cytokine production (Dalakas 2008). Ectopic follicles were found in the meninges of patients with secondary-progressive multiple sclerosis. It could be shown that these ectopic follicles were enriched with B cells and plasma cells (Serafini et al. 2004). Mathey and colleagues found that patients with progressive MS had an increased concentration of neurofascin, which is a neuronal protein found at the nodes of Ranvier. Injecting anti-neurofascin antibodies into mice with EAE caused a complement activation, which led to axonal conduction (Franciotta et al. 2008). Furthermore, oligoclonal bands, which are immunoglobilins, were found in the CSF of $90 \%$ MS patients throughout disease stages (Michel et al. 2015). Antibodies derived from the CSF of MS patients were able to cause a complement-mediated CNS injury through demyelination and astrocyte dysfunction in spinal cord samples of both mouse and human models (Blauth et al. 2015). Pattern II lesions, which are the most frequent lesion subtype found in MS patients, were first described by Lucchinetti and colleagues. This subtype of lesions shows immunoglobulin and complement depositions (Popescu et al. 2013). All these findings, mentioned above, confirm the important role of antibody production by plasma cells in the pathogenesis of MS. However, studies show that anti-CD20 therapy reduces the activity of relapsing MS, while the level of CSF antibodies seems to persist (Piccio et al. 2010). This therapeutic effect leads to the consideration that B cell depletion reduces new MS relapses through antibodyindependent roles of B cells (Michel et al. 2015). These findings lead to more intensive investigations on the other roles of $\mathrm{B}$ cells, such as antigen presentation and cytokine 
production. Some investigators consider that plasma cells and autoantibodies may play a more important role at the early stages of MS, as compared to later stages of the disease (Michel et al. 2015).

B cells may act as antigen-presenting cells (APC) via the activation of $\mathrm{T}$ cells. They initially recognize antigens with their surface $B$ cells receptor (BCR) and-present them to $T$ cells (Pöllinger et al. 2009). There is a theory that B cells may drain from the CNS into the lymph nodes, then presenting CNS antigens to T cells, which leads to T cell activation and mediates relapses (Michel et al. 2015). B cell activation requires two major signals. The first one produced by antigen through BCR cross-linking and the second one from $\mathrm{CD}^{+}{ }^{+} \mathrm{T}$ cells through the interaction of CD154 with the B cell surface receptor CD40. This interaction leads to B cell growth, proliferation, and production of costimulatory factors such as CD80 and $\mathrm{CD} 86$. Rodriguez-Pinto et al. showed in vivo that $\mathrm{B}$ cells can prime naïve $\mathrm{CD} 4^{+} \mathrm{T}$ cells in a CD154-CD40 dependent manner in the absence of other APC (Rodríguez-Pinto and Moreno 2005).

The third major function of B cells is the production of cytokines. Activated B cells can regulate inflammation through the secretion of pro-inflammatory and anti-inflammatory cytokines. Some B cells can secrete proinflammatory cytokines such as TNF, IL-6, GM-CSF, and Lymphotoxin-alpha, while other B cells play an anti-inflammatory role through secretion of IL-10 and IL-35. Investigations of recent years show that B cells from MS patients produce more pro-inflammatory- rather than anti-inflammatory cytokines (Bar-Or et al. 2010; Michel et al. 2015).

All these facts mentioned above, indicate an important role of B cells in the pathophysiology of MS. However, the strongest evidence of a crucial role of B cells in MS is the astonishing effect of anti-CD20 therapy. Investigators believe that the efficiency of this therapy occurs due to the loss of B cell cytokine-producing and antigen-presenting functions (Hauser et al. 2008).

\subsubsection{Therapy of multiple sclerosis}

The MS therapies can be divided into the following groups: treatment of acute attacks/relapses, treatment to prevent new relapses (disease-modifying therapy DMT), and symptomatic therapy.

New or worsening neurological symptoms lasting 24 hours or more in the absence of infection or fever are defined as MS relapses (Berkovich 2016). The therapy of acute relapses is an intravenous application of high dosed Methylprednisolone (common dosage is 1000 $\mathrm{mg} /$ day) for 3-5 days (Compston and Coles 2008). In case of unresponsiveness to the glucocorticoid therapy, plasma exchange should be considered (Ehler et al. 2017).

Disease-modifying therapies, such as glatiramer acetate or beta-interferons, were first introduced in the 1990s. They established safety and efficacy, although they had to be 
administered via injections (Cross and Naismith 2014). The following drugs can be used as basic therapy in patients with low disease activity: interferon-beta (IFN- $\beta$ ), glatiramer acetate (GA), teriflunomide (TERI), dimethyl fumarate (DMF).

In contrast to GA or IFN- $\beta$, DMF and TERI can be administered orally. These drugs show a high efficacy and safety profile and are generally well tolerated by patients (Cross and Naismith 2014). Since IFN- $\beta$ and GA require an administration via injections, they can cause skin reactions and flu-like symptoms (O'Connor et al. 2009). DMF is known to lead to adverse events such as gastrointestinal problems and flush. Teriflunomide should not be used within two years before pregnancy; because it is teratogenic. It is evident that all of these drugs reduce rates of MS relapses and decrease the rate of MS lesions (O'Connor et al. 2009; Fox et al. 2012; Kieseier et al. 2015; Ontaneda et al. 2018).

If there are MS relapses, new MRI lesions or a disability progress under the basic therapy, a so-called escalation therapy should be chosen. The drugs; shown below; are appropriate for the treatment of patients with disease activity: fingolimod, natalizumab, alemtuzumab, siponimod, cladribine.

These therapeutics are very effective but are not as safe as basic therapies. Fingolimod may cause bradyarrhythmia, herpes infection or liver injury (Akbulak et al. 2018). Therapy with Alemtuzumab can lead to thyroid-disorders, idiopathic thrombocytopenic purpura (ITP), and Good pasture syndrome. It has been considered that Alemtuzumab may cause a secondary auto-immunity in MS (Biernacki et al. 2017). Siponimod belongs to the sphingosine-1-phosphate (SIP) modulatory family such as Fingolimod. However, there is evidence that Siponimod-treated patients had a lower risk of adverse events such as bradycardia or vasoconstriction (Gajofatto 2017). Natalizumab is a selective adhesionmolecule inhibitor. It may lead to serious opportunistic infections, such as progressive multifocal leukoencephalopathy (PML) (Pardo and Jones 2017). It is known that patients having antibodies against the John Cunningham virus (JC virus) are associated with a higher PML risk (Zingaropoli et al. 2018). To estimate the individual risk of PML, antibodies against the JC-Virus should be measured before and during the therapy with Natalizumab (Ho et al. 2017). Cladribine selectively depletes lymphocytes. The major cladribine-associated adverse event is a herpes infection. Several phase III studies showed the efficacy of these drugs on reducing the disability progression, relapse rate, and MRI lesions (Grand'Maison et al. 2018; Pardo and Jones 2017).

Alternative escalation therapies include the following drugs: ocrelizumab, mitoxantrone.

There are only a few therapy options for the progressive forms of MS, SPMS and PPMS. Ocrelizumab is a monoclonal antibody, which selectively depletes CD20+ B cells. It was first approved by the US Food and Drug Administration (FDA) in 2017 (McGinley et al. 2017). Infections and infusion-related reactions are the most common adverse events associated with Ocrelizumab. Several studies demonstrated high efficacy of this therapy in reducing MS 
relapses, disability progression and MRI lesions (Montalban et al. 2017; Gelfand et al. 2017). Mitoxantrone is approved for its use in aggressive forms of MS without superimposed relapses. This drug may cause AML (Acute myeloid leukemia) or cardiac problems (Edan 2004; Buttmann 2018).

Neurorehabilitation is very important in the treatment of MS-associated symptoms. Such MS-related symptoms as fatigue, depression, and spasticity can be improved by cognitive behavioral therapy and various psychotherapeutic measures, such as individualized physiotherapy (Kesselring and Beer 2005; Veauthier and Paul 2016). Although there are several oral antispasticity drugs used in Germany, such as baclofen, tizanidine or sirdalud, the effectiveness of these drugs is low and they do not affect the disease progression (OteroRomero et al. 2016). Cannabidiol oromucosal spray was approved for the management of severe MS-related spasticity (Vermersch and Trojano 2016).

\subsection{Glatiramer acetate}

Glatiramer acetate or Copolymer 1 is a synthetic mixture composed of L-lysine, L-glutamic acid, L-alanine, and L-tyrosine, which are found in myelin basic protein (Sela and Teitelbaum 2001). It has been considered that myelin basic protein is the antigen causing an autoimmune reaction in MS and glatiramer acetate may play a role as a decoy for the immune cells. In 1996, Arnon et al. first showed that therapy with glatiramer acetate suppressed EAE in primates (Arnon 1996). Some successful clinical trials demonstrated that GA reduces relapse rate and progression of neurological disability so that in 1996 it was approved by the Food and Drug Administration under the brand name Copaxone for treatment of relapsingremitting MS (Johnson et al. 1995). Copaxone is usually administered by subcutaneous injections. Side effects of GA therapy are usually mild. Approximately $30 \%$ of patients develop injection-site reactions and about $10 \%$ of users may have a fever and flu-like symptoms (O'Connor et al. 2009; Stewart and Tran 2012). Subcutaneous administration of $20 \mathrm{mg} / \mathrm{mL}$ once a day is approved in many countries to treat MS patients with a relapsingremitting course. However, investigations of recent years showed that a high-concentration of glatiramer acetate $40 \mathrm{mg} / \mathrm{mL}$ administered three times a week reduced about $50 \%$ of injection-site reactions compared to daily GA $20 \mathrm{mg} / \mathrm{mL}$ administration. It is important to mention that the efficacy of the three-times-weekly regimen is similar to that of the 20 $\mathrm{mg} / \mathrm{mL}$ once-daily regimen (McKeage 2015). Several placebo-controlled studies showed that GA therapy delayed the conversion of clinically isolated syndrome (CIS) to clinically definite MS (Comi et al. 2013; Qizilbash et al. 2012).

\subsubsection{Mechanism of action of GA}

The precise mechanism of action of GA is still unknown. The therapeutic effect of glatiramer acetate is thought to be via neuroprotection and immunomodulation, for review see (McKeage 2015). Investigations suggest that GA treatment may affect T cells and B cells. 
Glatiramer acetate has historically been thought to be a T-cell targeting therapy. It was thought that the beneficial effect of this therapy occurred due to a shift of the T-cell balance from a pro-inflammatory phenotype (Th1/Th17) to an anti-inflammatory one (Th2/T regulatory cells) (Bakshi et al. 2013; Basile et al. 2006). Some investigators believe that the mechanism of glatiramer acetate is its cross-reaction with myelin basic protein and bystander suppression of T cells (Yong 2002; Haas et al. 2009). Bystander suppression means that GAspecific $T$ cells cross the blood-brain-barrier and secrete anti-inflammatory (Th2-specific) cytokines, inhibiting Th1 T cells (Aharoni et al. 1998). In vitro studies have shown that under GA therapy T cell lines secreted anti-inflammatory cytokines such as IL-10, IL-4, and TGF$\beta$. However, the level of pro-inflammatory cytokines secreted by T cells such as TNF $\alpha$ and IFN- $\gamma$ was decreased (Basile et al. 2006). In addition, it was demonstrated that GA-specific T cells can secrete brain-derived neurotrophic factor (BDNF) (Ziemssen et al. 2017). Similar findings could be demonstrated in the brains of GA-treated mice for neurotrophic factors such as neurotrophin NT3 and NT4, see review (Aharoni 2013). Thus, BDNF, NT3, and NT4 are important for neuronal survival (Lessmann et al. 2003), these findings show that GA may have some neuroprotective effects in patients with MS (Basile et al. 2006; Ziemssen et al. 2017). Regulatory $T$ cells (anti-inflammatory phenotype of $T$ cells) are functionally impaired in MS patients. Several studies showed that GA therapy restores the number and functionality of regulatory $T$ cells, which seems to have an additional anti-inflammatory effect (Putheti 2003; Haas et al. 2009).

Monocytes and macrophages play an important role in MS pathogenesis. They are believed to be responsible for tissue damage. They dominate in active MS lesions and myelin degradation products can be found inside macrophages (Lassmann et al. 2001; Sospedra and Martin 2005).

Several lines of evidence show that GA may affect the T-cell-stimulating properties of antigen-presenting cells (APC). Thus, using in vitro cultures have shown that dendritic cells (DCs), which are professional antigen-presenting cells, had an impaired capacity to secrete Th1-polarizing factors after the treatment with glatiramer acetate and therefore induced more T cells of the Th2 phenotype (Hussien et al. 2001; Vieira et al. 2003). Monocytes are a major subset of APCs, which can easily be obtained from peripheral blood. In 2004, Weber et al. demonstrated for the first time both in vitro and in vivo that GA inhibits monocyte reactivity (Weber et al. 2004). It was also shown that GA had an inhibitory effect on TNF- $\alpha$ production by monocytes ( $\mathrm{Li}$ et al. 1998). All these findings demonstrate that GA treatment leads to an additional anti-inflammatory effect through impairment of monocytes.

Once B cells cross the blood-brain barrier (BBB), factors such as BAFF (B-cell activating factor) and APRIL (a proliferation-inducing ligand), which are produced by astrocytes, play an essential role in their survival (Dooley et al. 2016). Thus, the presence of these two factors in MS lesions was associated with increased B cell survival rates (Avery et al. 2003; Krumbholz et al. 2005), leading to EAE and worsening of MS course (Krumbholz et al. 
2005). Begum-Haque et al. demonstrated that GA treatment downregulates the expression of BAFF and APRIL, as well as the BAFF receptor in mice with EAE (Begum-Haque et al. 2011). Furthermore, it could be demonstrated that GA reduces the concentration of cellbound adhesion molecules on immune cells, including B cells, such as molecule-3 on B cells (Sellner et al. 2013). This effect may reduce the extravasation of immune cells into the CNS.

Kala et al. showed reduced expression of CD80 and CD86 on B cells isolated from GAtreated EAE-diseased mice. CD80 and CD86 are known to stimulate the proliferation of autoreactive T cells (Kala et al. 2010).

Investigations show that B cells from MS patients lost their ability to produce the antiinflammatory cytokine IL-10, but produce more pro-inflammatory cytokines such as IL-6 and lymphotoxin-alpha (LT- $\alpha$ ) (Bar-Or et al. 2010). Several investigations on GA-treated EAE mice models could demonstrate that secretion of IL-10 by B cells was increased. Inflammatory cytokines such as IL-6 were reduced (Kala et al. 2010; Begum-Haque et al. 2011). Ireland et al. however, demonstrated that GA therapy may diminish the IL-6 and TNF- $\alpha$ production by B cells only transiently (Ireland et al. 2012). IL-10 inhibits the differentiation of naïve T cells into Th1 T cells and antigen-specific T cell proliferation (Kala et al. 2010). Another anti-inflammatory cytokine, which is produced both by B cells and regulatory T cells, is IL-13. Begum-Haque and colleagues demonstrated that B cells of GAtreated EAE mice also tended to produce more IL-13 (Begum-Haque et al. 2011).

In vitro studies showed that GA binds MHC class II molecules, displacing other peptides from the MHC binding groove, which may prevent or reduce antigen presentation to T-cells and T cells activation (Fridkis-Hareli et al. 1994).

Several investigations demonstrated that almost all patients treated with glatiramer acetate developed anti-GA (IgG) antibodies over time (Brenner et al. 2001; Teitelbaum et al. 2003; Begum-Haque et al. 2011). These antibodies did not correlate with adverse events or efficacy of GA treatment and had no neutralizing effect (Brenner et al. 2001). Teitelbaum et al. showed that anti-GA antibodies could even be detected after 2 years of GA treatment (Teitelbaum et al. 2003). The antibodies peaked at 3 months after the therapy was initiated, decreased at 6 months and stayed low (Karussis et al. 2010). Isotype and IgG subclass analysis showed that the significant GA-reactive antibodies are of the IgG4 subclass (Farina et al. 2002; Basile et al. 2006). This finding is important because IgG4 antibodies are associated with a shift to Th2 responses, as anti-inflammatory cytokines regulate isotype switching to IgG4 in plasma cells (Bomprezzi et al. 2011).

\subsection{Aims of the study}

As mentioned above, the effects of GA are still not fully understood. A 15-year follow-up study compared patients who continued with GA therapy to patients, who dropped out of the trial. It could be demonstrated that patients who continued the GA therapy had reduced 
relapse rates and decreased disability progression as compared to patients, who did not continue GA therapy (Ford et al. 2010).

It is unclear how GA affects antigen-presenting functions and cytokine production of both $\mathrm{B}$ cells and monocytes. Additionally, the effect on B cell activation is poorly investigated (Kala et al. 2010).

\subsubsection{Blood cell distribution}

It is known that GA reduces the total frequency of B cells and monocytes (Weber et al. 2004; Ireland et al. 2012). The current study aimed to re-evaluate the changes mentioned above and to analyze relative changes in the remaining lymphocyte pool. The peripheral blood mononuclear cells (PBMC's) of GA-treated and untreated patients were categorized by their surface molecules as follows:

Table 2: Blood cell distribution

\begin{tabular}{|lc|}
\hline B cells & $\mathrm{CD}^{+}{ }^{+}$ \\
\hline T-helper cells & $\mathrm{CD}^{+}$ \\
\hline Cytotoxic T cells & $\mathrm{CD}^{+}$ \\
\hline Monocytes & $\mathrm{CD}^{+} 4^{+}$ \\
\hline
\end{tabular}

\subsubsection{Cell survival}

In order to determine the fraction of necrotic and apoptotic cells, the cell status was defined as follows:

Table 3: Cell survival

\begin{tabular}{|lc|}
\hline Necrotic & Zombie $^{+}$ \\
\hline Apoptotic & size exclusion \\
\hline
\end{tabular}

\subsubsection{B cell subsets}

Several investigations show that GA therapy reduces the total frequency of B cells, plasmablasts and memory B cells (Ireland et al. 2014). The aim of this study was to determine $\mathrm{B}$ cell subsets and changes in their frequency in GA patients compared to untreated controls. Characterization of the $\mathrm{B}$ cell subsets can be performed through analysis of their surface molecules as follows: 
Table 4: B cell subsets

\begin{tabular}{|c|c|}
\hline Trans-B-cells & CD24high, CD27neg, CD38 high \\
\hline Mature B cells & CD24high, CD38low \\
\hline Activated B cells & CD27pos \\
\hline Memory B cells & $\mathrm{CD} 27^{\text {var }}, \mathrm{CD} 38^{\text {neg }}$ \\
\hline Plasmablasts & CD20 neg, CD27 high, $C D 38_{\text {high }}$ \\
\hline
\end{tabular}

\subsubsection{Activation markers on $B$ cells}

It is very important to differentiate B cells through their activation markers. Thus, in this context it is easier to understand the pathogenic antigen-presenting, antibody-secreting or cytokine-producing role of B cells. In this study following surface markers were used: CD25 (alpha chain of IL-2 receptor), expressed on activated mononuclear immune cells, which may stimulate through IL-2 T cell growth and effector functions (Malek 2008); CD40 (CD40L receptor), which is a costimulatory molecule, found on APCs and is required for their activation (Teitelbaum et al. 2003); CD69 (Early activation marker), a transmembrane protein, which is involved in lymphocyte migration and-activation (Vazquez et al. 2009); CD80 (Lymphocyte activating antigen B7-1), a protein found on monocytes, activated B cells ;and dendritic cells, which plays an important role in T cell activation and survival (Aung und Balashov 2015); CD86 (Lymphocyte activating antigen B7-2), a protein expressed on APCs, which plays a crucial role in T cell activation and survival (Aung und Balashov 2015); MHC II, usually found on APCs,-plays an important role in the initiation of immune responses; CD95 (Apoptosis antigen 1; Fas receptor), a protein, which plays an important role immune cells apoptosis.

As mentioned above, the antigen-presenting functions of $\mathrm{B}$ cells and monocytes/macrophages seem to play an important role in the pathogenesis of MS (Teitelbaum et al. 2003; Aharoni 2013). To quantify the antigen-presenting function, the expression of MHC II and co-stimulatory molecules (CD80, CD86, CD40) was measured on $\mathrm{B}$ cells and monocytes in peripheral blood.

\subsubsection{Cytokine production}

As mentioned above, cytokine production by immune cells plays an important role in MS pathogenesis. Glatiramer acetate has been considered to stimulate the production of antiinflammatory cytokines and reduce the secretion of pro-inflammatory ones (Begum-Haque 
et al. 2010). In order to quantify the cytokines production of B cells and monocytes, three major cytokines as IL-6, IL-10 and TNF- $\alpha$ were measured in this study: Interleukin 6 (IL-6) plays a crucial role in the pathogenesis of neuroinflammatory diseases. Investigations in a murine model of MS, (EAE), showed complete resistance to disease induction in mice lacking IL-6, see for review (Rothaug et al. 2016). Furthermore, IL-6-deficiency impaired Th17 differentiation in a defective manner (Hernandez et al. 2015). These findings show that IL-6 is a pro-inflammatory cytokine. Interleukin 10 (IL-10) is an anti-inflammatory cytokine, predominantly produced by myeloid cells and lymphocytes (Moore et al. 2001). IL-10 suppresses the expression of pro-inflammatory cytokines, costimulatory factors on APCs and T effector functions (Ireland et al. 2015). Tumor necrosis factor alpha (TNF- $\alpha$ ) is a proinflammatory cytokine, produced by macrophages, but also by lymphocytes, neurons, and other cells. TNF- $\alpha$ has similar effects on immune cells as IL-6. TNF- $\alpha$ is involved in inflammation and apoptosis and stimulates phagocytosis of macrophages (Locksley et al. 2001). 


\section{$2 \quad$ Material and Methods}

\subsection{Patients}

The blood samples were drawn from patients of the Göttingen University Medical Center in Germany between 2015 and 2018 with confirmed RRMS. The diagnosis of RRMS was based on the McDonald criteria. The 22 MS patients treated with GA were compared to 18 untreated MS patients. Treated patients were taking GA for at least three months when the blood samples were drawn. Six patients treated with GA were analyzed longitudinally, meaning that-blood samples were taken at two different time points with an interval of at least three months. The patients did not receive any kind of immunotherapy before GA. Additionally, a sample from a healthy person was used as an internal control.

Table 5: The disease and demographic characteristics of the patients

\begin{tabular}{|l|l|l|}
\hline & Untreated & GA-treated \\
\hline Number of patients & 18 & 22 \\
\hline Age $(y)($ mean \pm SD) & $32.4 \pm 9.7$ & $42 \pm 9.4$ \\
\hline Female sex $(\%)$ & $77.7 \%$ & $54.5 \%$ \\
\hline EDSS score (mean \pm SD) & $2.1 \pm 1.7$ & $2 \pm 1.4$ \\
\hline Disease duration (y) (mean \pm SD) & $4.7 \pm 6.2$ & $7.4 \pm 6.1$ \\
\hline GA since (m) (mean \pm SD) & - & $5.9 \pm 4.1$ \\
\hline
\end{tabular}




\subsection{Materials}

Table 6: Human monoclonal antibodies for flow cytometry

\begin{tabular}{|c|c|c|c|c|}
\hline Antigen & Fluorochrome & Clone & Dilution & $\begin{array}{l}\text { Manufacturing } \\
\text { company }\end{array}$ \\
\hline $\mathrm{CD} 4$ & PE-Cy7 & RPA-T4 & $1: 100$ & BD Biosciences \\
\hline $\mathrm{CD} 8$ & PE & HIT-8a & $1: 100$ & eBioscience \\
\hline $\mathrm{CD} 14$ & BV421 & M5E2 & $1: 100$ & BD Biosciences \\
\hline $\mathrm{CD} 14$ & PE-CF594 & $\mathrm{M} \varphi \mathrm{P} 9$ & $1: 100$ & BD Biosciences \\
\hline CD19 & APC & HIB19 & $1: 100$ & BD Biosciences \\
\hline CD19 & FITC & HIB19 & $1: 100$ & BD Biosciences \\
\hline CD19 & PerCp-Cy5.5 & HIB19 & $1: 100$ & BioLegend \\
\hline CD19 & PE-Cy5 & HIB19 & $1: 100$ & BD Biosciences \\
\hline $\mathrm{CD} 20$ & APC-Cy7 & $\mathrm{L} 27$ & $1: 100$ & BD Biosciences \\
\hline $\mathrm{CD} 24$ & PerCp-Сy5.5 & ML5 & $1: 100$ & BioLegend \\
\hline $\mathrm{CD} 25$ & BV605 & ВC96 & $1: 100$ & BioLegend \\
\hline $\mathrm{CD} 27$ & PacificBlue & $\mathrm{O} 323$ & $1: 100$ & BioLegend \\
\hline CD38 & FITC & HIT2 & $1: 100$ & BioLegend \\
\hline $\mathrm{CD} 40$ & PE/Dazzle & $5 \mathrm{C} 3$ & 1:100 & BioLegend \\
\hline CD69 & FITC & FN50 & $1: 100$ & BioLegend \\
\hline $\mathrm{CD} 80$ & PE-Cy7 & L307.4 & $1: 100$ & BD Biosciences \\
\hline CD86 & BV421 & FUN-1 & $1: 100$ & BD Biosciences \\
\hline $\mathrm{CD} 95$ & PE & DX2 & $1: 100$ & BioLegend \\
\hline CD150 & BV421 & A12 & $1: 100$ & BD Biosciences \\
\hline MHC II & APC & Tü36 & $1: 100$ & BioLegend \\
\hline IL-6 & FITC & MQ2-13A5 & $1: 50$ & BD Biosciences \\
\hline IL-10 & PE-CF594 & JES3-19F1 & $1: 50$ & BD Biosciences \\
\hline TNF & A700 & MAb11 & $1: 50$ & BD Biosciences \\
\hline Dead/Live & ZombieAqua $^{\mathrm{TM}}$ & & $1: 100$ & BioLegend \\
\hline Dead/Live & ZombieNIR ${ }^{\mathrm{TM}}$ & & $1: 100$ & BioLegend \\
\hline
\end{tabular}


Table 7: Reagents, protein and inhibitors

\begin{tabular}{|c|c|}
\hline Product & Manufacturing company \\
\hline BD FACS Clean ${ }^{\mathrm{TM}}$ & BD Biosciences \\
\hline BD FACS Flow ${ }^{\mathrm{TM}}$ & BD Biosciences \\
\hline BD FACS Rinse ${ }^{\mathrm{TM}}$ & BD Biosciences \\
\hline BioColl separation solution & Biochrom \\
\hline CpG oligodeoxynucleotides & Sigma Aldrich \\
\hline Cytofix/Cytoperm ${ }^{\mathrm{TM}}$ & BD Biosciences \\
\hline DMEM (Dulbecco's Modified Eagle's medium) & Sigma Aldrich \\
\hline DMSO (Dimethyl-sulfoxide) & Sigma Aldrich \\
\hline $\begin{array}{l}\text { EDTA (Ethylene diamine tetraacetic acid } \\
\text { disodium salt dihydrate) }\end{array}$ & Carl Roth \\
\hline Ethanol $100 \%$ & Merck Millipore \\
\hline Fc-block $^{\mathrm{TM}}$ & BioLegend \\
\hline FCS (fetal calf serum) & Sigma Aldrich \\
\hline GolgiPlug ${ }^{\mathbf{T M}}$ & BD Biosciences \\
\hline Ionomycin & Sigma Aldrich \\
\hline LPS (lipopolysaccharide) & Sigma Aldrich \\
\hline PBS (phosphate buffered salt solution) & Sigma Aldrich \\
\hline Perm/Wash ${ }^{\mathrm{TM}}$ buffer, 10x & BD Biosciences \\
\hline PFA (para-formaldehyde) & Merck Millipore \\
\hline PMA (Phorbol 12-Myristrate 13 Acetate) & Sigma Aldrich \\
\hline $\begin{array}{l}\text { RPMI-1640 (Roswell park memorial institute- } \\
\text { 1640) }\end{array}$ & Sigma Aldrich \\
\hline Sodium pyruvate $100 \mathrm{mM}$ & Sigma Aldrich \\
\hline TMB (tetramethylbenzidine) & eBioscience \\
\hline TrypanBlue & SigmaAldrich \\
\hline$\beta$-mercaptoethanol & Sigma Aldrich \\
\hline
\end{tabular}


Table 8: Solutions, buffers and cell culture media

\begin{tabular}{|c|c|}
\hline Solution & Composition \\
\hline Cryo-medium & $\begin{array}{l}60 \% \text { RPMIcomplete, } 20 \% \text { FCS, } 20 \% \\
\text { DMSO }\end{array}$ \\
\hline ELISA blocking buffer & $\begin{array}{l}1.81 \text { distilled water, } 200 \mathrm{ml} \text { PBS } 10 \mathrm{x}, 20 \mathrm{~g} \\
\text { BSA }\end{array}$ \\
\hline ELISA coating buffer & $\begin{array}{l}11 \text { distilled water, } 8.4 \mathrm{~g} \text { NaHCO3, } 3.5 \mathrm{~g} \\
\text { NACO3 }\end{array}$ \\
\hline ELISA stop solution & $1 \mathrm{M} \mathrm{H} 2 \mathrm{SO} 4$ solution \\
\hline ELISA wash buffer & $\begin{array}{l}1.81 \text { distilled water, } 200 \mathrm{ml} \text { PBS } 10 \mathrm{x}, 1 \mathrm{ml} \\
\text { Tween }\end{array}$ \\
\hline FACS buffer & $2 \% \mathrm{FCS}$ in PBS \\
\hline RPMIcomplete & $\begin{array}{l}0.51 \mathrm{RPMI}-1640,50 \mathrm{ml} \mathrm{FCS}, 5 \mathrm{ml} \text { sodium } \\
\text { pyruvate, } 5 \mathrm{ml} \text { L-glutamine, } 0.5 \mathrm{ml} \beta \text { - } \\
\text { mercaptoethanol }\end{array}$ \\
\hline
\end{tabular}

Table 9: Coonsumables

\begin{tabular}{|l|l|}
\hline Product & Manufacturing company \\
\hline 96 well plates, flat bottom & Sarstedt \\
\hline 96 well plates, round bottom & Sarstedt \\
\hline FACS tubes, $5 \mathrm{ml}$ & Sarstedt \\
\hline Micro tubes $(0.1 \mathrm{ml}, 0.5 \mathrm{ml}, 1 \mathrm{ml}, 1.5 \mathrm{ml})$ & Eppendorf \\
\hline Multistep pipettes, $1 \mathrm{ml}$ & Eppendorf \\
\hline Nunc ${ }^{\text {TM }} 96 \mathrm{well} \mathrm{ELISA} \mathrm{plates}$ & ThermoScientific \\
\hline Pipettes $(10 \mu \mathrm{l}, 200 \mu \mathrm{l}, 1000 \mu \mathrm{l})$ & Sarstedt \\
\hline Pipettes $(5 \mathrm{ml}, 10 \mathrm{ml}, 25 \mathrm{ml})$ & Sarstedt \\
\hline
\end{tabular}


Table 10: Technical devices

\begin{tabular}{|l|l|}
\hline Device & Manufacturing company \\
\hline BBD 6220 cell incubator & ThermoScientific \\
\hline Centrifuge 5415R & Eppendorf \\
\hline Centrifuge 5810R & Eppendorf \\
\hline CKX41 light microscope & Olympus \\
\hline FACS LSRII Fortressa & BD Biosciences \\
\hline IMARK ${ }^{\mathrm{TM}}$ microplate reader & Bio-Rad \\
\hline Neubauer chamber & Superior Marienfeld \\
\hline SAFE 2020 clean bench & ThermoScientific \\
\hline
\end{tabular}

Table 11: Software

\begin{tabular}{|c|c|}
\hline Software & Company \\
\hline Microplate Manager $6^{\mathrm{TM}}$ & Bio-Rad \\
\hline FACSdiva ${ }^{\text {TM }} 6.1 .2$ & BD biosciences \\
\hline FlowJo $^{\text {TM }} 10.2$ & Tree Star Inc. \\
\hline GraphPad Prism ${ }^{\mathbf{T M}} 6.01$ & GraphPad software Inc. \\
\hline Excel & Microsoft Office 2016 \\
\hline
\end{tabular}

\subsection{Methods}

All steps of PBMC isolation and cryopreservation were done according to the protocol, which was established in this laboratory.

\subsubsection{Preparation of human peripheral blood mononuclear cells (PBMC)}

The blood samples were drawn from the patients into EDTA tubes. Then, the blood was filled into a $50 \mathrm{ml}$ tube and diluted with PBS. In the next step, the blood suspension was layered very carefully and slowly onto $20 \mathrm{ml}$ of BioColl ${ }^{\mathrm{TM}}$ in another $50 \mathrm{ml}$ tube. After a 35minute centrifugation at 1500 revolutions per minute $(\mathrm{rpm})$ and $21{ }^{\circ} \mathrm{C}$ with low acceleration and brake, the „ring” (the white layer), representing the peripheral blood mononuclear cells, was withdrawn, suspended in a new tube, and diluted with DMEM. After a ten-minute 
centrifugation at $1250 \mathrm{rpm}$ and $4{ }^{\circ} \mathrm{C}$, the cell pellet was washed a second time with DMEM. The next step was to count the cells, solved in $5 \mathrm{ml} \mathrm{DMEM}$. For this purpose, the cell suspension was diluted with DMEM to a concentration of $4 * 10^{6} \mathrm{ml}^{-1}$. Each cryo tube was filled with $500 \mu \mathrm{l}$ of the cell suspension and $500 \mu \mathrm{l}$ cryo-medium. A total cell count of 2 million cells per tube was achieved this way. The cryo tubes were stored at $-80{ }^{\circ} \mathrm{C}$ in the ethanol cooling boxes until further steps of the experiments.

\subsubsection{FACS (fluorescence-activated cell sorting) panels and stimulation regime}

Different FACS panels and stimulation regimes were established to examine the aims of this study. The developed panels and stimulation regimes were tested and optimized before the patients' blood samples were used. The established FACS panels are shown below:

Table 12: FACS panels (1)

\begin{tabular}{|l|l|l|}
\hline Cell distribution (b) & B cell subsets (a) & Cytokine production (d) \\
\hline CD4 - PE-Cy7 & CD19 - APC & CD14 - BV421 \\
\hline CD8 - PE & CD20 - APC-Cy7 & CD19 - PE-Cy5 \\
\hline CD14 - PE-CF594 & CD24 - PerCp-Cy5.5 & IL-6 - FITC \\
\hline CD19 - FITC & CD27 - PacificBlue & IL-10 - PE-CF594 \\
\hline CD150 - BV421 & CD38 - FITC & TNF - A700 \\
\hline MHC II - APC & CD95 - PE & ZombieNIR \\
\hline ZombieAqua & ZombieAqua & \\
\hline
\end{tabular}


Table 13: FACS panels (2)

\begin{tabular}{|l|l|}
\hline Activation markers (c) & Antigen-presenting function (e) \\
\hline CD19 - PerCp-Cy5.5 & CD14 - FITC \\
\hline CD25 - BV605 & CD19 - PerCp-Cy5.5 \\
\hline CD40 - PE/Dazzle & CD40 - PE/Dazzle \\
\hline CD69 - FITC & CD80 - PE-Cy7 \\
\hline CD80 - PE-Cy7 & CD86 - BV421 \\
\hline CD86 - BV421 & MHC II - APC \\
\hline MHC II - APC & CD95 - PE \\
\hline CD95 - PE & ZombieNIR \\
\hline ZombieNIR & \\
\hline
\end{tabular}

In some panels, the cells were stimulated and incubated, because some activation markers and cytokines are only expressed or synthesized upon stimulation. For this purpose, the following substances were used: Lipopolysaccharide (LPS), a large molecule consisting of a lipid and a polysaccharide, found in the outer membrane of gram-negative bacteria. It is known that immune cells produce pro-inflammatory cytokines upon LPS binding to the TRL4 receptor; CPG (cytosine-phosphate-guanine), which is a dinucleotide and has a high abundance in microbial genomes. Due to this fact, CPG is recognized by immune cells as a pathogen-associated molecule. It promotes cytokine and antibody production. Ionomycin enhances the intracellular calcium level and stimulates the intracellular production of cytokines. It is an ionophore produced by the bacterium Streptomyces conglobatus; PMA or phorbol 12-myristate 13-acetate is commonly used together with Ionomycin to stimulate the intracellular cytokine production via a protein kinase $\mathrm{C}(\mathrm{PKC})$ pathway. 
Table 14: Stimulation regimes

\begin{tabular}{|l|l|}
\hline FACS Panel & Stimulation regime \\
\hline Cell distribution (b) & No stimulation \\
\hline B cell subsets (a) & No stimulation \\
\hline Antigen-presenting function (e) & No stimulation \\
\hline Cell distribution (b) & $100 \mathrm{pg} / \mathrm{ml}$ LPS for $20 \mathrm{~h}$ \\
\hline Activation markers (c) & $2 \mu \mathrm{g} / \mathrm{ml} \mathrm{CpG} \mathrm{for} 20 \mathrm{~h}$ \\
\hline Cytokine production (d) & $\begin{array}{l}1 \mu \mathrm{g} / \mathrm{ml} \text { CpG for } 20 \mathrm{~h}, \text { then }+ \text { GolgiPlug, after } 2 \mathrm{~h}+500 \\
\mathrm{ng} / \mathrm{ml} \text { Ionomycin and } 20 \mathrm{ng} / \mathrm{ml} \text { PMA for } 2 \mathrm{~h}\end{array}$ \\
\hline
\end{tabular}

\subsubsection{Unfreezing, cell counting and seeding}

To unfreeze cells, the cell containing cryo-tubes had to be put in a $37^{\circ} \mathrm{C}$ water quench for 30 seconds. Each of the frozen cryo-tubes contained two million cells and was stored at -80 ${ }^{\circ} \mathrm{C}$. After thawing, the cell suspension was put into $40 \mathrm{ml}$ RPMI. Each patient's sample was thawed in a different tube. The next step was centrifugation $\left(1250 \mathrm{rpm}, 4{ }^{\circ} \mathrm{C}, 10\right.$ minutes). After that the supernatant was discarded, and the sedimented cells were re-suspended in 1 $\mathrm{ml}$ RPMI for counting. For this purpose, a Neubauer chamber was used. In order to exclude dead cells, $10 \mu \mathrm{l}$ cell suspension was diluted in $10 \mu \mathrm{l}$ or $90 \mu \mathrm{l}$ Trypan Blue (prediluted 1:10 in PBS), resulting in a dilution factor of 2 and 10, respectively. $10 \mu \mathrm{l}$ of the mixture was given onto the counting chamber to count the cells. Hereby the following formula was used:

\section{Total cell count $=\frac{\text { Counted cells }}{4} * 10000 *$ dil.fac. $*$ volume of suspension $[\mathrm{ml}]$}

The cell suspension was then diluted with RPMI to a concentration of $2 * 10^{6}$ cells $/ \mathrm{ml}$. A total of 200 '000 cells $(100 \mu \mathrm{l}$ of the prepared cell suspension) were plated per well. All patient samples were measured in duplicates. Additional cells were plated for single stainings. Ubottom 96-well plates were used for unstimulated panels. The staining of those samples was done on the same day, as shown below.

For stimulated panels flat bottom 96-well plates were used. $100 \mu \mathrm{l}$ of CpG and LPS were added to the cell suspension, according to the stimulation regimes. The stimulated plates were incubated at $37{ }^{\circ} \mathrm{C}$ and $5 \% \mathrm{CO}_{2}$ for $20 \mathrm{~h}$. Supernatants were frozen at $-18{ }^{\circ} \mathrm{C}$ until further examination. 


\subsubsection{Live/Dead staining}

In order to exclude dead- from living cells, a Zombie ${ }^{\mathrm{TM}}$ dye was used. This dye reacts with primary amine groups on proteins. In dead cells, where the cell membrane is not intact, the dye enters and binds all kinds of proteins within the cytoplasm. These cells appear brighter in Zombie ${ }^{\mathrm{TM}}$ fluorescence than living cells. In living cells, in which the membrane is intact, the dye can only bind to surface proteins.

After standard centrifugation $\left(1250 \mathrm{rpm}, 4{ }^{\circ} \mathrm{C}, 7 \mathrm{~min}\right)$ and re-suspension in $200 \mu \mathrm{l} \mathrm{PBS}$, the second centrifugation took place. After the supernatant was discarde; the cells were resuspended in $30 \mu \mathrm{l}$ of the pre-diluted Zombie dye (1:500 in PBS). This excluded nonZombie single stainings, which were resuspended in PBS. Thereafter the plates were incubated for $10 \mathrm{~min}$ at room temperature in the dark. Then the cells were washed in $200 \mu \mathrm{l}$ FACS buffer.

\subsubsection{Surface staining}

In order to avoid the non-specific binding of antibodies to Fc receptors on the cell surface, $30 \mu \mathrm{Fc} \mathrm{F}^{-b l o c k}{ }^{\mathrm{TM}}$ (pre-diluted 1:100 in FACS buffer) was added to the cells in each well. After an incubation of 10 minutes at $4{ }^{\circ} \mathrm{C}$ in the dark, the cells had to be washed with $170 \mu \mathrm{FACS}$ buffer. Thereafter standard centrifugation $\left(1250 \mathrm{rpm}, 4^{\circ} \mathrm{C}, 7 \mathrm{~min}\right)$ took place. After draining the supernatant, a surface staining was performed. For this purpose, a mastermix of fluorophore-labeled antibodies diluted 1:100 in FACS buffer was assembled for each panel. The $30 \mu \mathrm{l}$ of the resulting mastermix, containing all fluorophores for one panel, was added to each patient sample. Single antibodies, which were used for single stainings, were also diluted 1:100 in FACS buffer. After an incubation of 15 minutes at $4{ }^{\circ} \mathrm{C}$ in the dark, the cells were washed twice with FACS buffer $(140 \mu \mathrm{l}$ and $150 \mu \mathrm{l})$ and then resuspended in $100 \mu \mathrm{l}$ FACS buffer. The cell suspension was given into $5 \mathrm{ml} \mathrm{FACS} \mathrm{tubes} \mathrm{for} \mathrm{analysis.}$

\subsubsection{Intracellular staining}

After 20 hours of CpG stimulation, $10 \mu$ GolgiPlug $^{\mathrm{TM}}$ (pre-diluted 1:10 in RPMI) per well was added to the cells leading to a blockage of the Golgi apparatus and the accumulation of synthesized proteins inside the cells. After two hours, $50 \mu$ l Ionomycin and $50 \mu \mathrm{l}$ PMA were added to each well. This step resulted in an even higher production of cytokines. Because of the Golgi apparatus inhibition, these cytokines accumulated inside the cells. After 2 hours of incubation, the cells were centrifuged. $230 \mu \mathrm{l}$ supernatant of each well was stored at $-18{ }^{\circ} \mathrm{C}$ in 96-well plates until further examination. The cells were stained for cell death and surface molecules, as shown in 2.3.4 and 2.3.5. 
After the surface staining, $100 \mu \mathrm{l} \mathrm{Fix} /$ Perm $^{\mathrm{TM}}$ was added to fix the cells and increase cell permeability. After an incubation of 30 minutes at $4{ }^{\circ} \mathrm{C}$ in the dark, the cells were centrifuged. Thereafter the cells were washed with $200 \mu \mathrm{l} \mathrm{Perm} / \mathrm{Wash}^{\mathrm{TM}}$ per well. Then $50 \mu \mathrm{l}$ of prepared intracellular antibody mix (pre-diluted 1:50 in Perm/Wash ${ }^{\mathrm{TM}}$ ) was put onto the cells. The cells were then incubated for 18 hours at $4{ }^{\circ} \mathrm{C}$ in the dark. Thereafter the cells were washed twice in $100 \mu \mathrm{l} \mathrm{Perm} / \mathrm{Wash}^{\mathrm{TM}}$ and $200 \mu \mathrm{l} \mathrm{FACS} \mathrm{buffer.} \mathrm{Then} \mathrm{the} \mathrm{cell} \mathrm{suspension} \mathrm{was}$ resuspended in $100 \mu \mathrm{l}$ FACS buffer and put into $5 \mathrm{ml} \mathrm{FACS}$ tubes.

\subsubsection{Flow cytometry}

The fluorescence-activated cell sorting (FACS) was used to analyze the fluorophore-labeled cells. For this purpose, the LSRII Fortessa FACS machine by BD Biosciences was used. The cell suspension was acquired to record a maximum of 100000 events for each tube. The same procedure was repeated for each tube. The same compensation was applied for all runs to make the comparison between the different runs more valid. The obtained data was analyzed with the Flowjo 10.2 software.

\subsubsection{Gating}

The next step was to determine the percentage of B cells, according to their characteristic cell surface molecules (2.3.2). In addition, B cells were divided into subgroups according to the gating strategy, as shown below: 
A

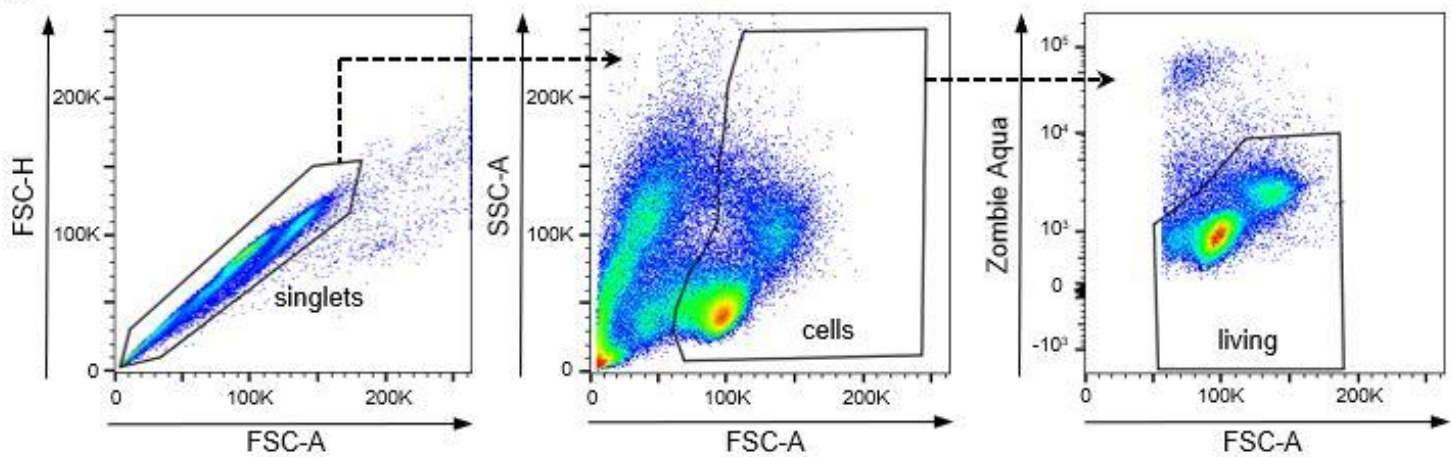

B

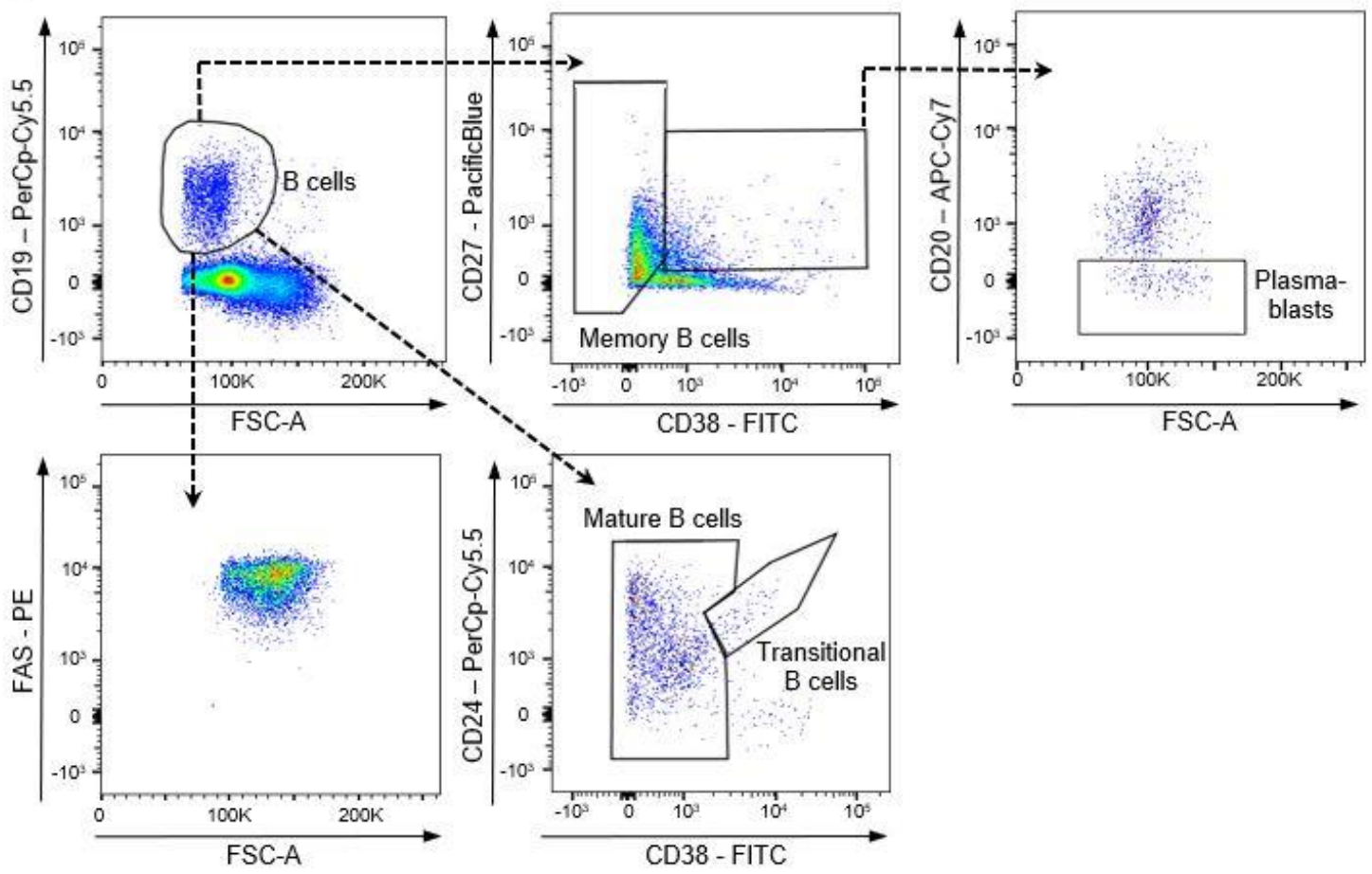

Figure 1: Pre-gating and gating strategy for B cell subsets and surface molecule expression.

(A) Singlets were gated to exclude doublets. Non-apoptotic cells were determined by size exclusion in FSC-A and SSC-A. Non-necrotic cells, meaning Zombie-negative cells were gated and defined as living cells. (B) The B cells gate was defined as CD19+, Memory B cells (CD27varCD38 neg), Plasmablasts (CD27 high CD38 high CD20 neg), Mature B cells (CD24high CD38low), transitional B cells (CD24high CD27neg CD38 high).

\subsubsection{Statistical analysis}

The data of the patient groups were tested for Gauss distribution using the D'Agostino \& Pearson omnibus normality test, the Shapiro-Wilk normality test, and the Kolmogorov-

Smirnov normality test. For the comparison of two cross-sectional groups with Gauss distribution, an unpaired and for longitudinal samples, a paired t-test was used, respectively. If the data was not Gauss distributed, a Mann Whitney test was applied in the cross-sectional 
analysis and the Wilcoxon matched-pairs signed-rank test was used for the longitudinal data. We also determined whether the cell distribution, B cell subsets, expression of surface markers, and cytokine production (variable 1) were correlated with GA-therapy duration (variable 2). For these purposes a Pearson's correlation coefficient, which is denoted by letter $\mathrm{r}$, was determined. Pearson's correlation coefficient is the statistical association between two variables. $\mathrm{R}$ varies between -1 and 1 . Zero means there is no correlation, 1 means a complete or perfect correlation, and a negative $r$ means that the variables are negatively inversed. When the correlation $r$ is negative the regression slope, which is also negative.

$\mathrm{R}^{2}$ which is the coefficient of determination shows the proportion of the variability of the dependent variable that can be attributed to its linear relation with the independent variable.

GraphPad Prism ${ }^{\text {TM }} 6$ was utilized for all statistical analyses. A p-value $<0.05$ was considered statistically significant. 


\section{Results}

Each sample of a GA-treated patient was measured together with a sample of an untreated patient in one run. In order to see if all experiments were performed under similar conditions, a sample of a healthy person was used (internal control) in all runs.

\subsection{Cell distribution}

\subsubsection{GA has no effect on monocyte frequencies}

There was no significant difference in the total amount of monocytes (being defined as CD14 positive cells) within the PBMC pool in the cross-sectional and longitudinal analyses of blood samples upon or without GA treatment. Stimulation with LPS did not cause any significant changes in the total amount of $\mathrm{CD} 14^{+}$cells within the PBMC pool of GA-treated patients compared to untreated controls. 

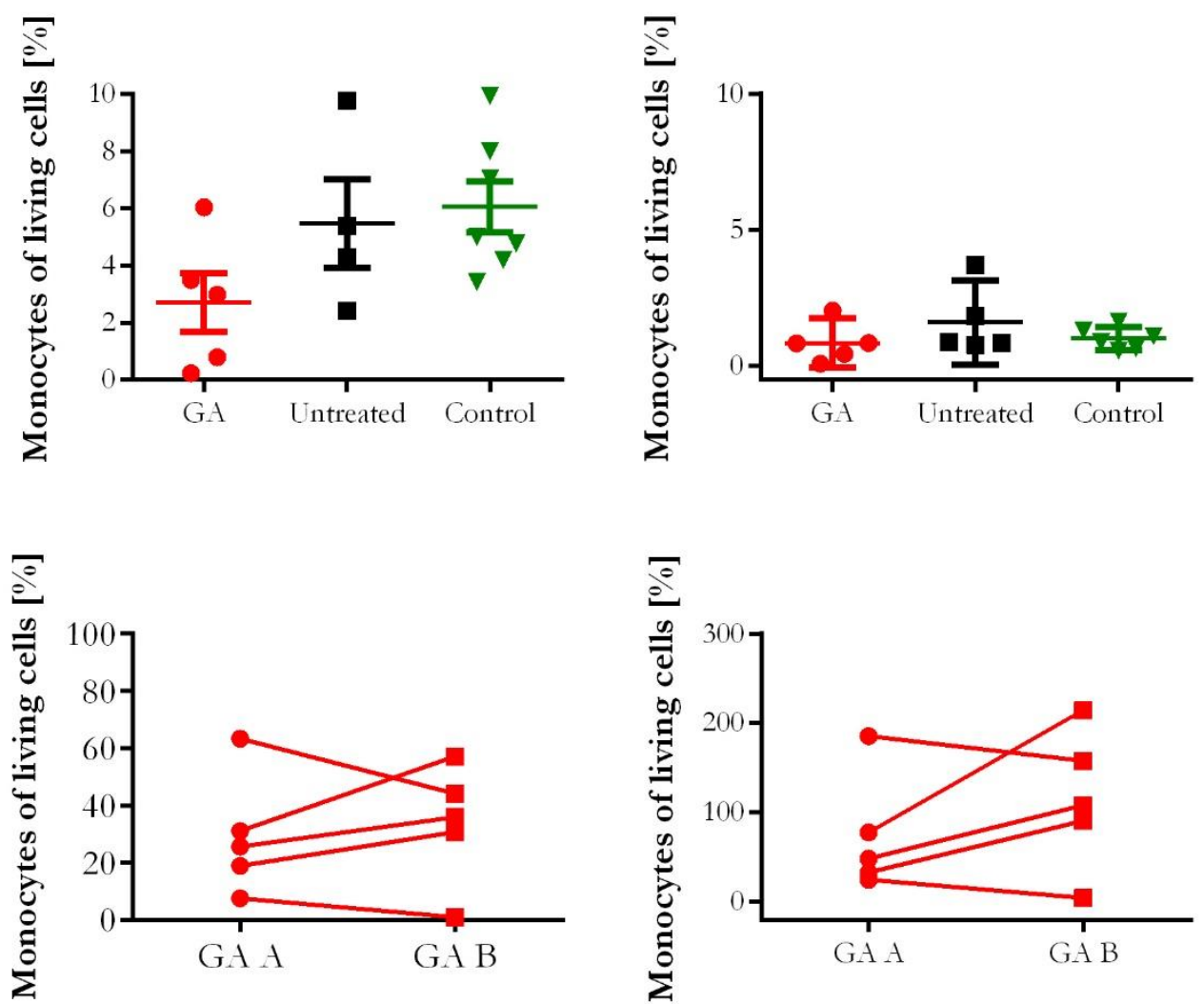

Figure 2: Monocyte frequency [\% of Monocytes].

The upper graphs show individual patient data of the unstimulated $n=5$ (GA); $n=4$ (untreated); (upper left), and LPS stimulated $n=5(\mathrm{GA}) ; \mathrm{n}=5$ (untreated), (upper right) cross-sectional experiment. Mean \pm SEM is represented by whiskers. Lower graphs demonstrate the frequency of monocytes in the longitudinal analyses of blood samples of GA-treated RRMS patients in unstimulated $\mathrm{n}=5$ (GA sample A and GA sample B), (lower left) and LPS stimulated measurements $\mathrm{n}=5$ (GA sample A and GA sample B), (lower right). In order to demonstrate that all longitudinal experiments were performed under the same conditions, each sample was relativized to the internal control.

\subsubsection{GA has no effect on $T$ cell frequencies}

The total frequency of $T$ cells was determined by analyzing the frequency of $\mathrm{CD} 4^{+}$and $\mathrm{CD} 8^{+}$ cells. GA had no effect on $\mathrm{CD} 8^{+}$cells, also known as cytotoxic $\mathrm{T}$ cells. There was either no effect on $\mathrm{CD}^{+}{ }^{+} \mathrm{T}$ cells upon GA therapy. 


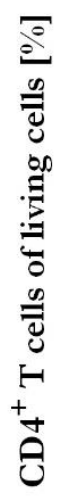

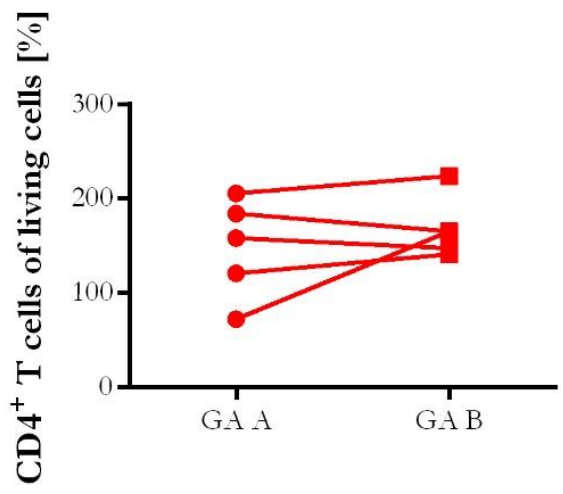

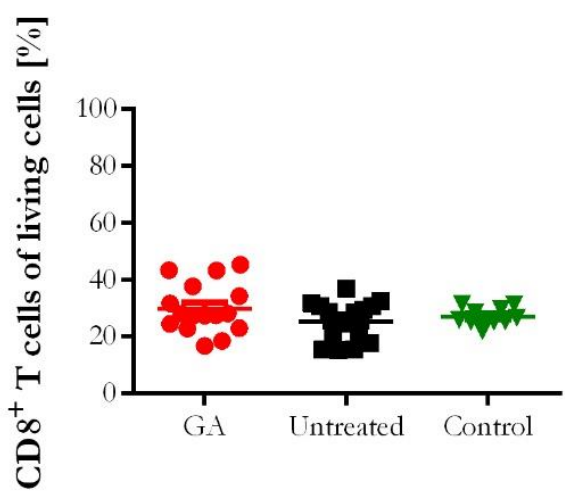

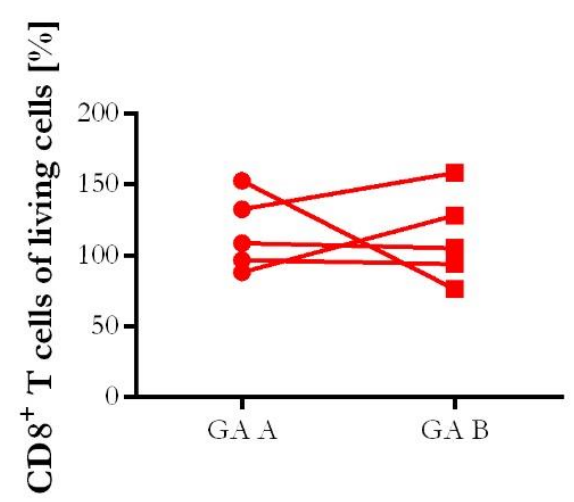

Figure 3: $\mathrm{T}$ cell frequency [ $\%$ of $\mathrm{T}$ cells $]$.

Changes in T cell subsets were analyzed in the unstimulated regimen. The upper graphs give an overview of $\mathrm{CD}^{+}{ }^{+} \mathrm{n}=16(\mathrm{GA}) ; \mathrm{n}=13$ (untreated) and $\mathrm{CD}^{+} \mathrm{T}$ cells $\mathrm{n}=13(\mathrm{GA}) ; \mathrm{n}=16$ (untreated) in cross-sectional analyses of blood samples. Mean \pm SEM is represented by whiskers. Lower graphs demonstrate the frequency of $T$ cells in longitudinal analyses of blood samples of GA-treated RRMS patients $n=5$ (GA sample A and GA sample B). In order to demonstrate that all longitudinal experiments were performed under the same conditions, each sample was relativized to the internal control.

\subsubsection{GA reduces $B$ cell frequencies}

There was no significant change in the total amount of B cells in GA-treated patients when compared to untreated patients both in unstimulated and CPG stimulated experiments. However, it could be demonstrated that the B cell frequency was significantly reduced upon GA treatment in the longitudinal blood samples when stimulated with $2 \mu \mathrm{g} / \mathrm{ml}$ CPG. 

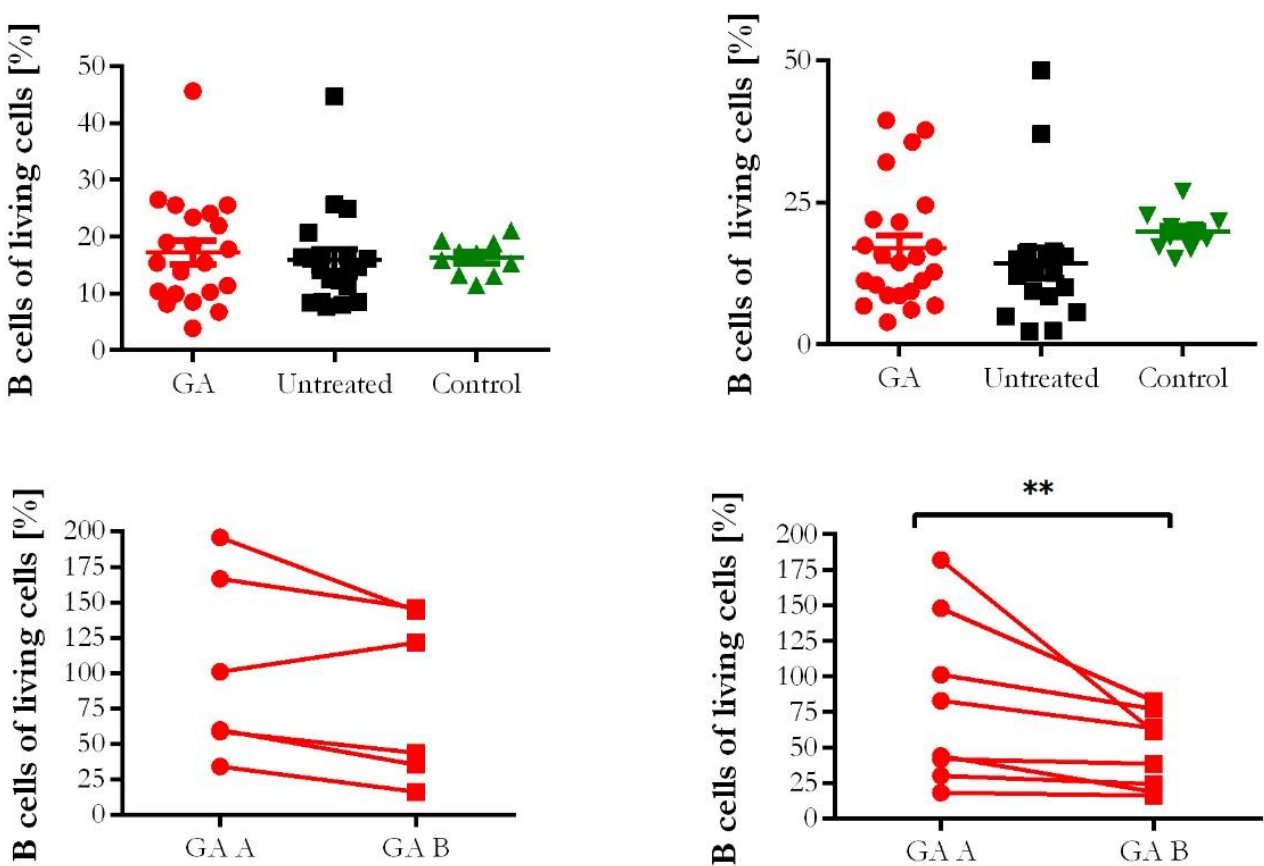

Figure 4: B cell frequency [\% of B cells].

The left upper graphs show individual patient data of the unstimulated $n=21$ (GA); $n=20$ (untreated), (upper left) and CPG stimulated $n=23$ (GA); $n=18$ (untreated), (upper right) crosssectional experiment. Mean \pm SEM is represented by whiskers. Lower graphs demonstrate the significant reduction of $B$ cells in longitudinal analyses of blood samples of GA-treated RRMS patients in unstimulated $n=6$ (GA sample $A$ and GA sample B; lower left) and CPG stimulated measurement $\mathrm{n}=8$ (GA sample $\mathrm{A}$ and GA sample $\mathrm{B}$; lower right), (**= $\mathrm{p}<0.01$; unpaired $\mathrm{t}$-test). In order to demonstrate that all longitudinal experiments were performed under the same conditions, each sample was relativized to the internal control.

\subsection{The effect of GA on monocytes}

The expression of activation markers such as CD150 and MHC II was examined on unstimulated monocytes (CD14 ${ }^{+}$cells) and after LPS stimulation with $100 \mathrm{pg} / \mathrm{ml} \mathrm{LPS.}$

\subsubsection{GA has no effect on the expression of CD150 on monocytes}

There were no significant changes in CD150 expression on monocytes in both the crosssectional and longitudinal experiments. 

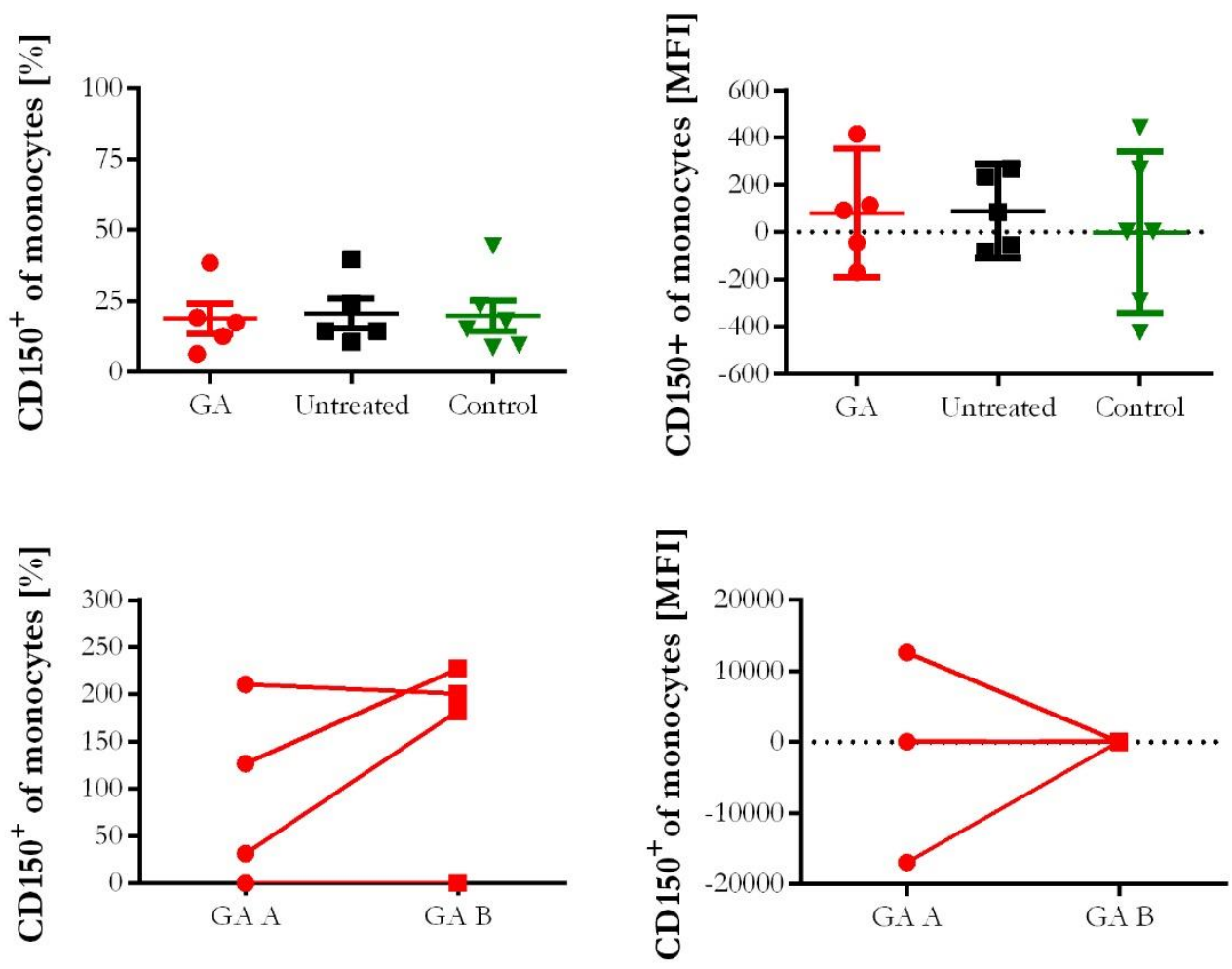

Figure 5: CD150+ Monocytes [\% of Monocytes].

The left upper graph shows individual patient data in percentage of monocytes $n=5(\mathrm{GA}) ; n=5$ (untreated), the upper right one shows $\mathrm{CD} 150^{+}$monocytes in MFI n= 5 (GA); $n=5$ (untreated). Mean \pm SEM is represented by whiskers. Lower graphs demonstrate the expression of CD150 on monocytes in the longitudinal analyses of blood samples of GA-treated RRMS patients in percentage of monocytes $n=4$ (GA sample $A$ and GA sample B), (lower left) and MFI $n=3$ (GA sample A and GA sample B), (lower right). In order to demonstrate that all longitudinal experiments were performed under the same conditions, each sample was relativized to the internal control.

\subsubsection{GA has no effect on the MHC II expression on monocytes}

As the antigen-presentation of monocytes plays an important role in the pathogenesis of MS, MHC II expression was examined on monocytes. There were no significant changes in the expression of MHC II on monocytes in both our cross-sectional and longitudinal groups. 

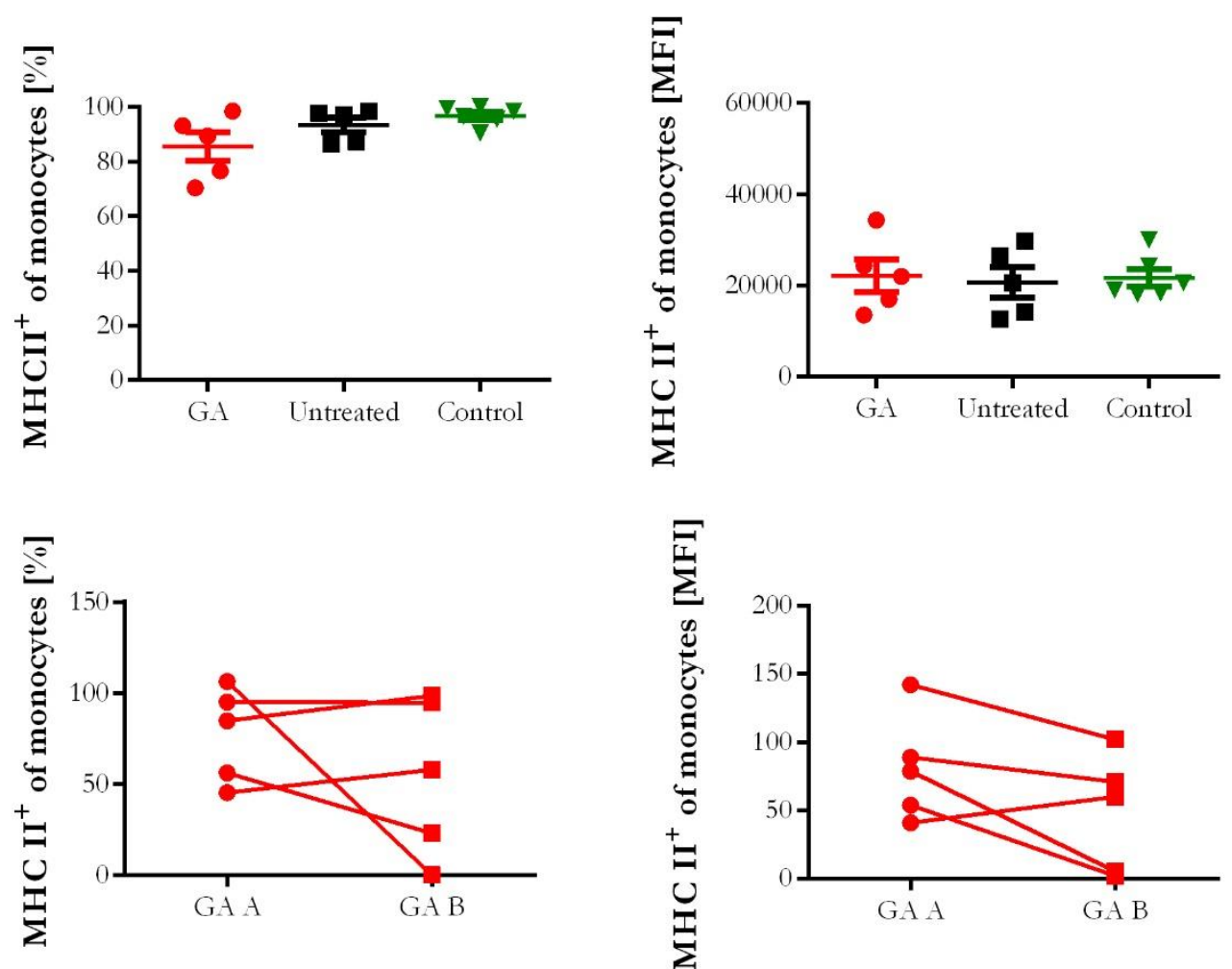

Figure 6: MHC $\mathrm{II}^{+}$Monocytes [\% of Monocytes].

The left upper graphs show individual patient data in percentage of monocytes $n=5(G A) ; n=5$ (untreated), the upper right one shows MHC $\mathrm{II}^{+}$monocytes in MFI $\mathrm{n}=5$ (GA); $\mathrm{n}=5$ (untreated), in cross-sectional experiment. Mean \pm SEM is represented by whiskers. Lower graphs demonstrate the expression of MHC II on monocytes in the longitudinal analyses of blood samples of GA-treated RRMS patients in percentage of monocytes (lower left) and MFI (lower right), $n=5$ (GA sample A and GA sample B). In order to demonstrate that all longitudinal experiments were performed under the same conditions, each sample was relativized to the internal control.

\subsection{B cell subsets}

The different $\mathrm{B}$ cell subsets were determined, as presented in the table 4. 


\subsubsection{GA downregulates the frequency of transitional B cells}

The intermediate stage of immature and mature B cells are transitional cells, which were determined as $\mathrm{CD} 24^{\text {high }}, \mathrm{CD} 27^{\text {neg }}, \mathrm{CD} 38^{\text {high }}$. There was no difference in the total frequency of transitional B cells upon GA treatment compared to their untreated controls. However, a significant reduction of transitional B cells could be observed in longitudinal samples, which also negatively correlated with GA treatment duration.
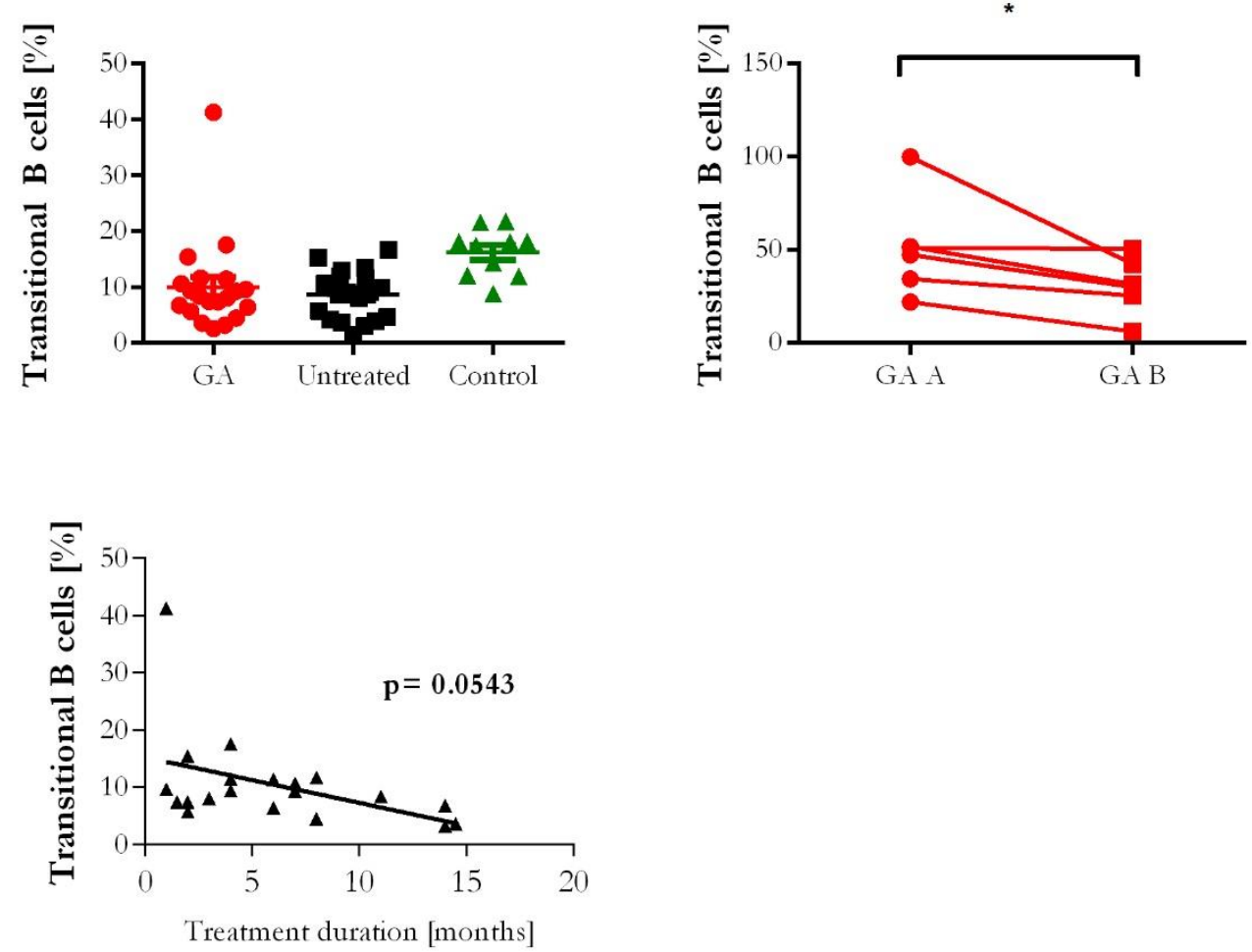

Figure 7: Transitional B cell frequency [\% of B cells].

The proportion of transitional B cells (CD24high, CD27neg, CD38 high) stayed unaffected during GA therapy in the cross-sectional analysis. The left upper graph shows individual patient data of the unstimulated cross-sectional experiment, $n=20$ (GA); $n=19$ (untreated). Mean \pm SEM SD is represented by whiskers. There was a significant reduction in the total amount of transitional B cells in the longitudinal samples. The right graph demonstrates the significant downregulation of transitional B cells in longitudinal analyses of blood samples of GA-treated RRMS patients in unstimulated measurement, $\mathrm{n}=6$ (GA sample A and GA sample B), (*= $\mathrm{p}<0.05$; Mann Whitney test). In order to demonstrate that all longitudinal experiments were performed under the same conditions, each sample was relativized to the internal control. The left lower graph shows the amount of transitional B cells in relation to GA treatment duration. The trend line is based on linear progression. 


\subsubsection{GA has no effect on mature $B$ cells}

Mature B cells were defined as CD24 $4^{\text {high }}$, CD $38^{\text {low }}$ cells. There was no impact of GA on mature B cells in both cross-sectional and longitudinal analyses of blood samples. However, a trend in the relation between the frequency of mature B cells and GA treatment duration could be observed.
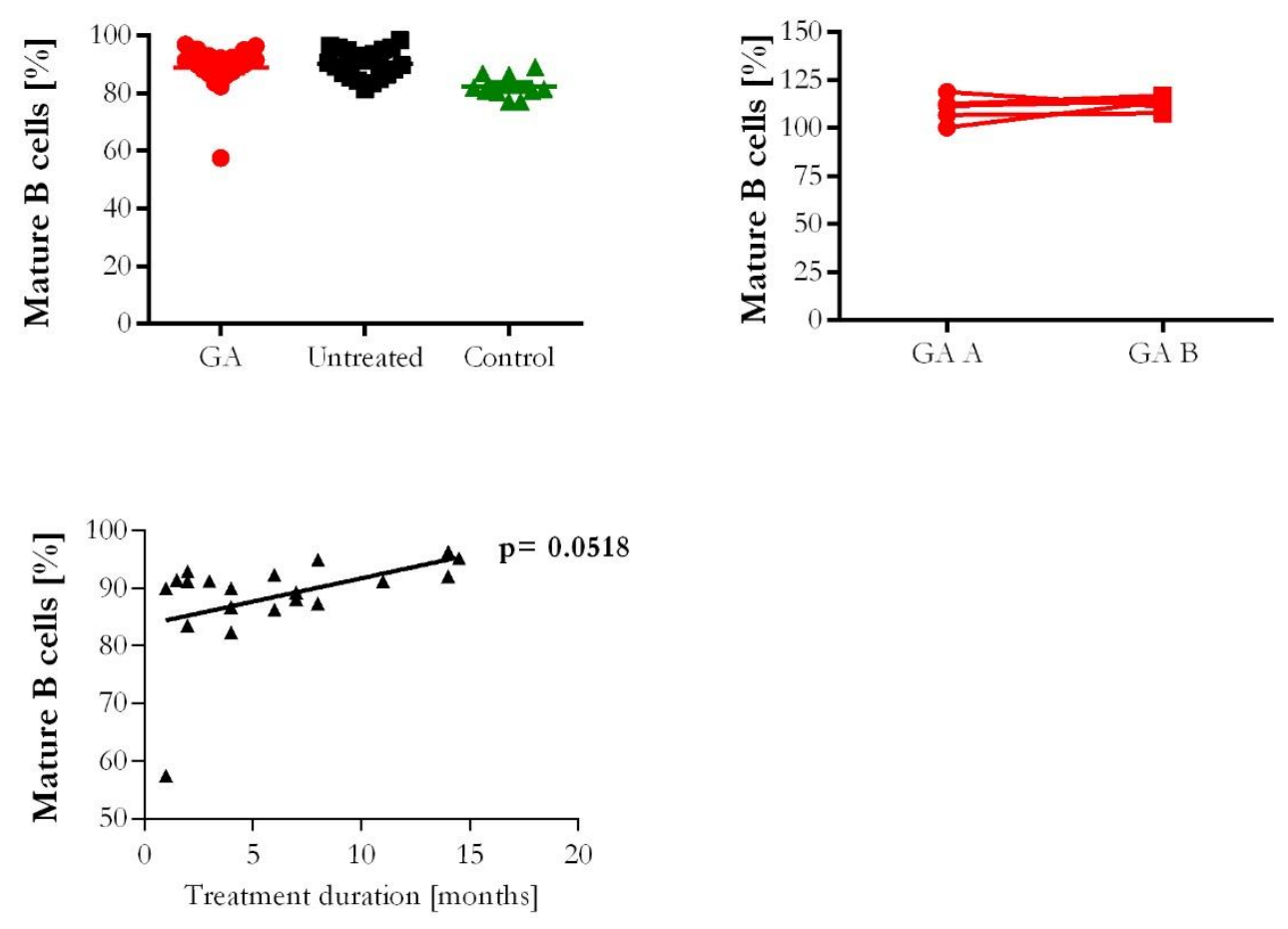

Figure 8: Mature B cell frequency [\% of B cells].

The left upper graph shows individual patient data of the unstimulated cross-sectional experiment, $\mathrm{n}=21(\mathrm{GA}) ; \mathrm{n}=20$ (untreated). Mean \pm SEM is represented by whiskers. The right graph demonstrates the frequency of mature B cells in longitudinal analyses of blood samples of GA-treated RRMS patients in unstimulated measurements, $n=6$ (GA sample A and GA sample B). In order to demonstrate that all longitudinal experiments were performed under the same conditions, each sample was relativated to the internal control. The left lower graph shows the amount of mature B cells in relation to GA treatment duration. The trend line is based on linear progression.

\subsubsection{GA has no effect on activated B cells}

Activated B cells are known to have a high expression of CD27. GA had no impact on the total frequency of activated B cells compared to untreated patients. There were also no significant changes in the total amount of $\mathrm{CD} 27^{+} \mathrm{B}$ cells in the longitudinal analyses of blood samples of GA-treated RRMS patients. 

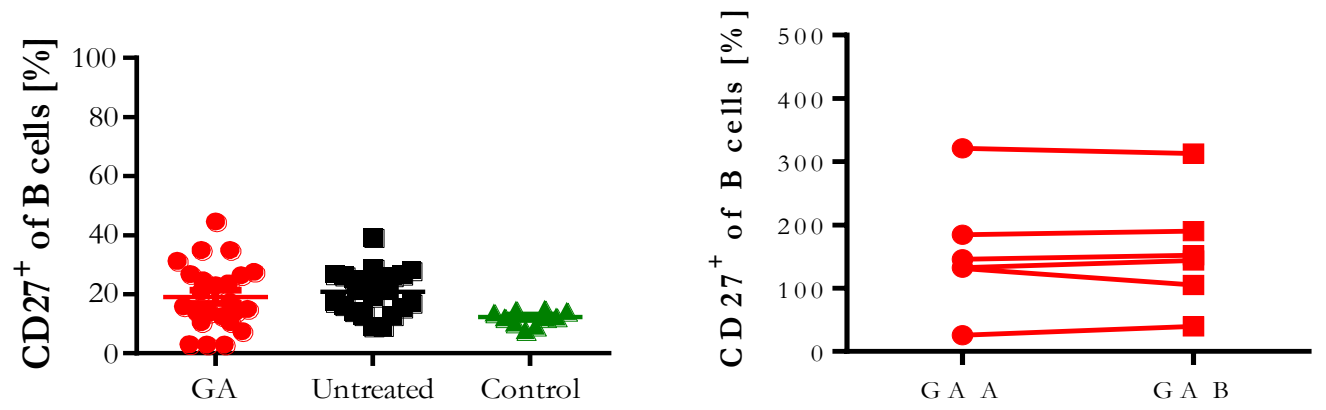

Figure 9: Activated B cell frequency [\% of B cells].

The left graph shows individual patient data of the unstimulated cross-sectional experiment $n=21$ (GA); $n=20$ (untreated). Mean \pm SEM is represented by whiskers. The right graph demonstrates the frequency of activated B cells in longitudinal analyses of blood samples of GA-treated RRMS patients in unstimulated measurements, $n=6$ (GA sample A and GA sample B). In order to demonstrate that all longitudinal experiments were performed under the same conditions, each sample was relativized to the internal control.

\subsubsection{GA treatment has no effect on memory B cell frequency}

Memory B cells play an important part in the secondary immune response. These cells are defined as CD27 $7^{\text {var }}, \mathrm{CD} 38^{\text {neg }}$. There was no difference in the frequencies of memory B cells in GA-treated patients compared to untreated controls. The total amount of memory B cells also stayed unchanged in the longitudinal experiments.
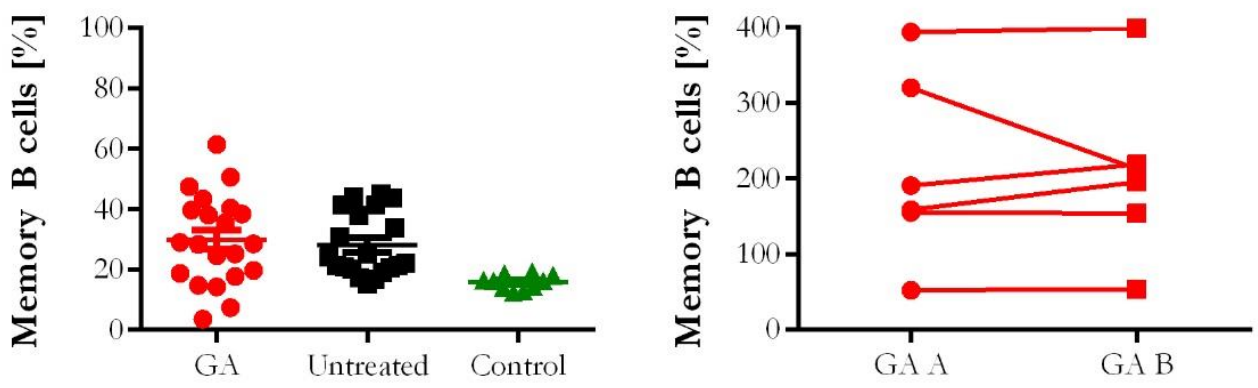

Figure 10: Memory B cell frequency [\% of B cells].

The left graph shows individual patient data of the unstimulated cross-sectional experiment, $n=21$ (GA); $\mathrm{n}=20$ (untreated). Mean \pm SEM is represented by whiskers. The right graph demonstrates the frequency of memory B cells in the longitudinal analyses of blood samples of GA-treated RRMS patients in unstimulated measurements, $\mathrm{n}=6$ (GA sample $A$ and GA sample B). In order to demonstrate that all longitudinal experiments were performed under the same conditions, each sample was relativized to the internal control. 


\subsubsection{GA decreases the total amount of plasmablasts}

Plasmablasts were defined as $\mathrm{CD} 20^{\text {neg }}, \mathrm{CD} 27^{\text {high }}, \mathrm{CD} 38^{\text {high }} \mathrm{B}$ cells. Interestingly, GA decreased the frequency of plasmablasts $(2.78 \pm 0.43 \%)$ when compared to untreated controls $(4.68 \pm 0.66 \%)$. This effect could also be demonstrated in the longitudinal experiments.
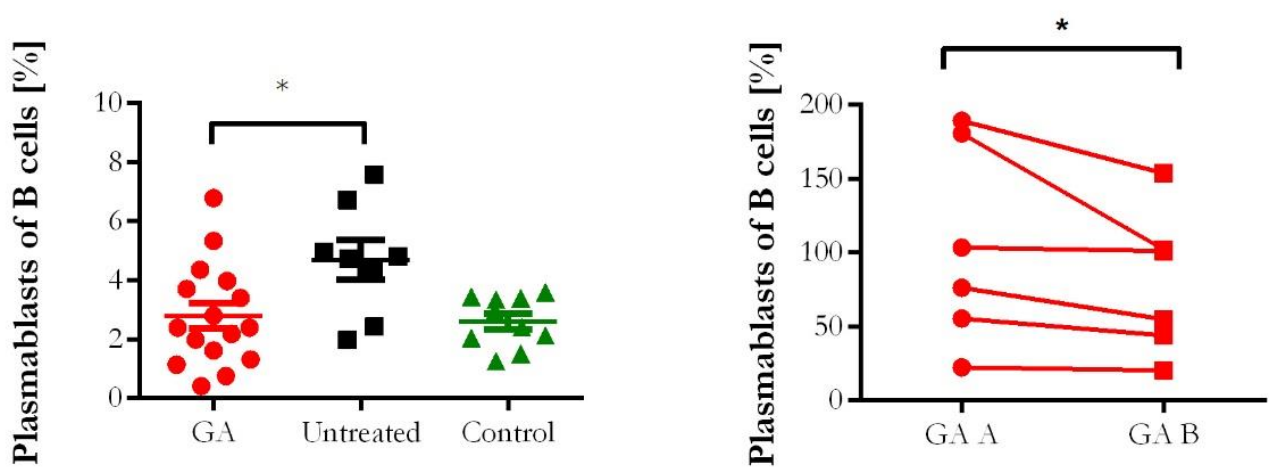

Figure 11: Pasmablast frequency [\% of B cells].

The left graph shows individual patient data of the unstimulated cross-sectional experiment, $\mathrm{n}=16$ (GA); $\mathrm{n}=8$ (untreated). Mean \pm SEM is represented by whiskers. The right graph demonstrates the frequency of plasmablasts in longitudinal analyses of blood samples of GA-treated RRMS patients in unstimulated measurements, $\mathrm{n}=6$ (GA sample A and GA sample B), $\left(^{*}=\mathrm{p}<0.05\right.$; Mann Whitney test). In order to demonstrate that all longitudinal experiments were performed under the same conditions, each sample was relativized to the internal control.

\subsubsection{Changes in B cell subsets after GA therapy}

In summary, there was a significant reduction in the total amount of plasmablasts in both the cross-sectional and longitudinal analyses of blood samples of GA-treated RRMS patients. In addition, a significant reduction of transitional B cells was observed in the longitudinal samples. For a detailed correlation between the B cell subsets and GA therapy duration, see table 16. 

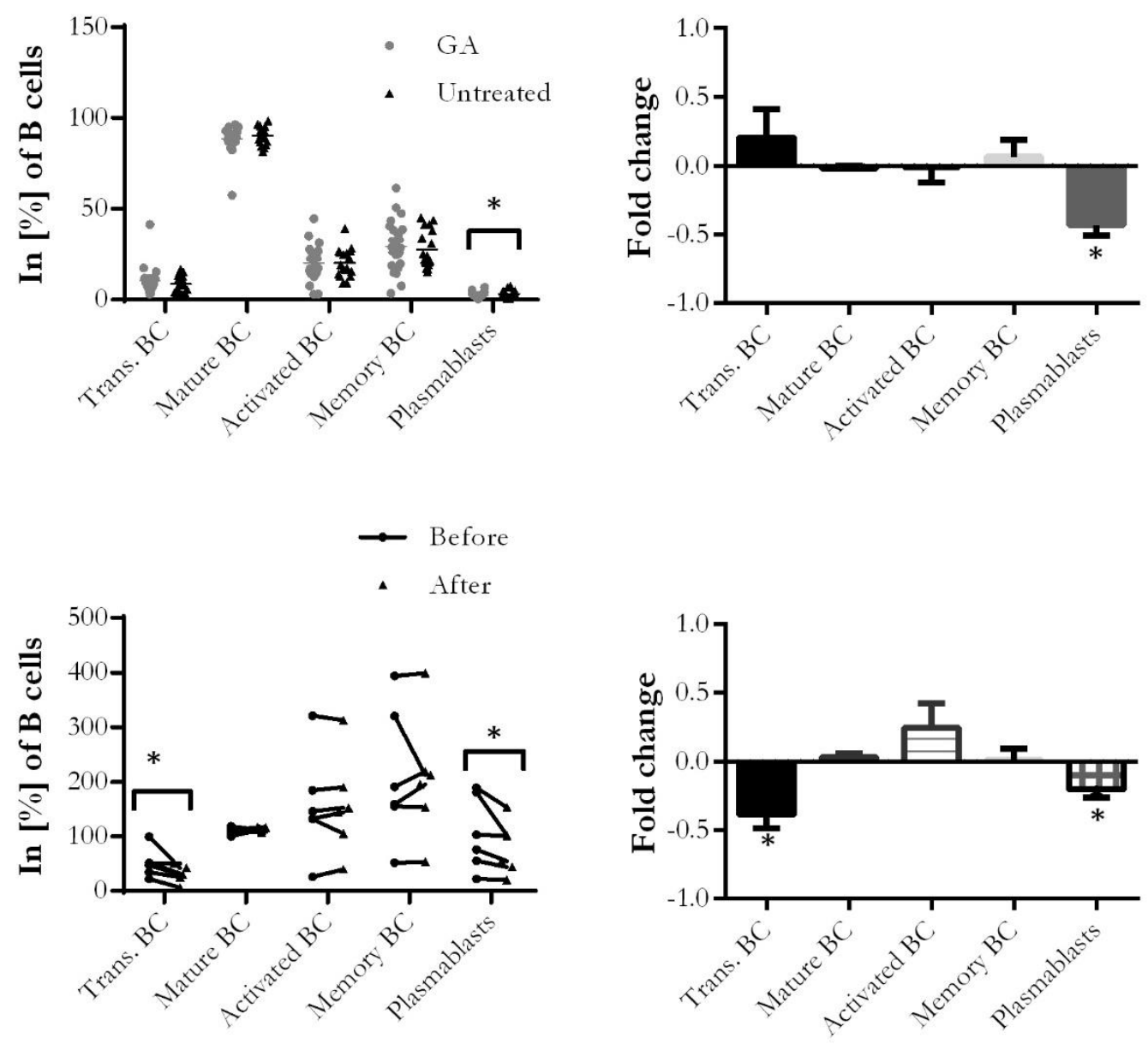

Figure 12: Changes in the B cell subsets after GA therapy.

The left upper graph provides a summary of the B cell subset frequencies in the cross-sectional samples. The right upper graph demonstrates the relative changes of the B cell subtypes in the crosssectional samples. The left lower graph provides a summary of the different B cell subset changes in the longitudinal samples. The right lower graph demonstrates the relative changes of the $\mathrm{B}$ cell subtypes in the longitudinal samples. There was a significant reduction in the total amount of plasmablasts in both the cross-sectional $(*=\mathrm{p}<0.05$; unpaired $\mathrm{t}$-test $)$ and longitudinal samples $(* *=$ $\mathrm{p}<0.01$; Mann Whitney test). Additionally, there was a significant reduction in the frequency of transitional B cells in the longitudinal samples. In order to demonstrate that all longitudinal experiments were performed under the same conditions, each sample was relativized to the internal control. 


\subsection{B cell activation}

The expression of activation markers on B cells was measured using both the frequency of positive cells and the mean fluorescence intensity (MFI). In order to upregulate the expression of activation markers, B cells were stimulated with CpG.

\subsubsection{GA reduces the expression of CD25 on stimulated B cells}

There was a significant reduction of CD25 expression on B cells, when the blood samples of GA-treated RRMS patients were analyzed in a longitudinal manner. However, no differences in CD25 expression could be observed when the blood samples of GA-reated patients were compared to their untreated controls.
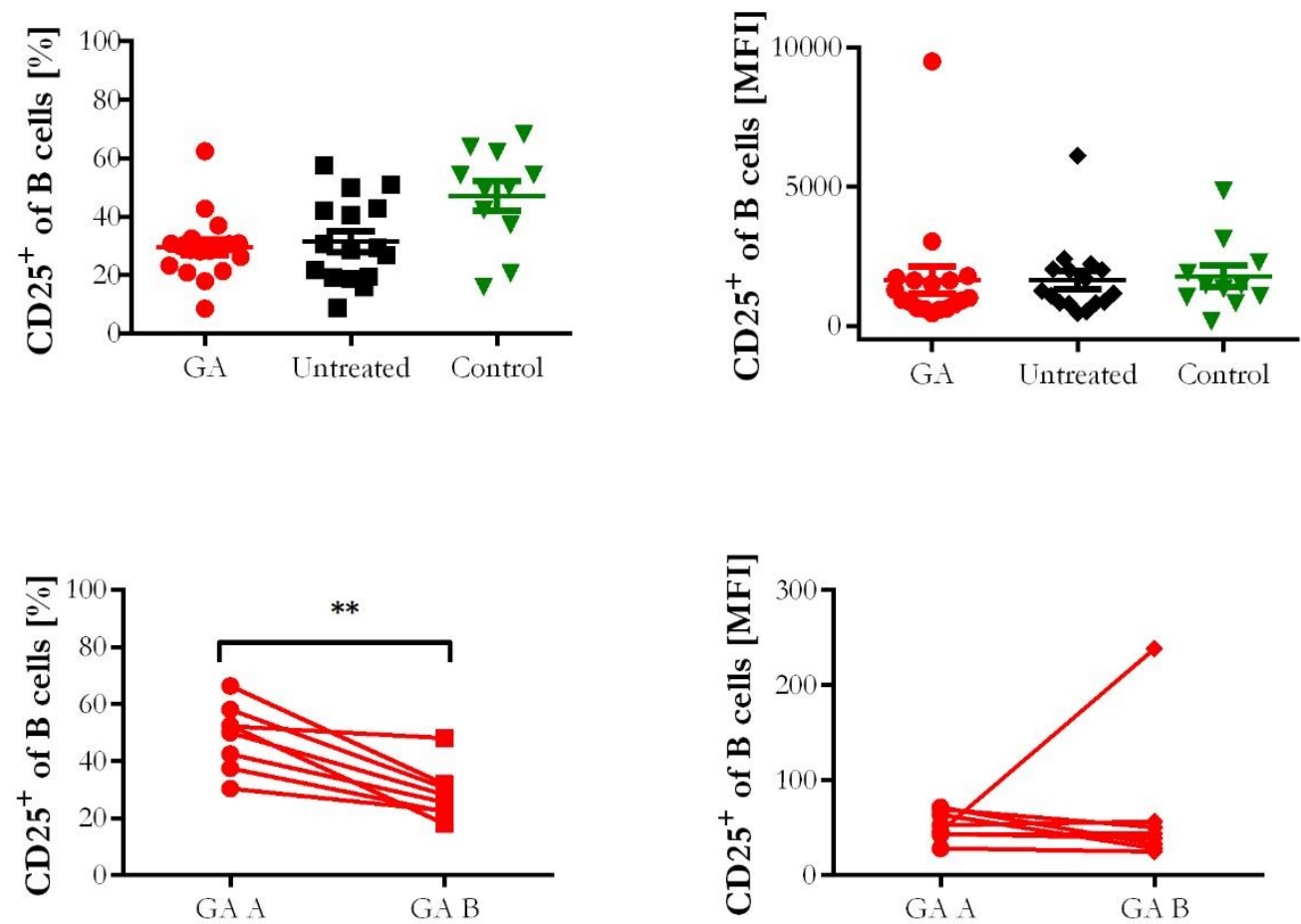

Figure 13: $\mathrm{CD} 25^{+} \mathrm{B}$ cells $[\%$ of $\mathrm{B}$ cells].

There were no significant changes in the expression of CD25 on the surface of B cells in the crosssectional samples. The upper graphs show individual patient data in MFI (upper right) and percentage of $B$ cells (upper left) in cross-sectional experiments, $n=22$ (GA); $n=18$ (untreated). Mean \pm SEM is represented by whiskers. Lower graphs demonstrate the expression of CD25 on B cells in the longitudinal analyses of blood samples of GA-treated RRMS patients in MFI (lower right) and percentage of $B$ cells (lower left), $n=8$ (GA sample A and GA sample B). GA downregulated the CD25 expression on B cells (**= $\mathrm{p}<0.01$; Mann Whitney test). In order to demonstrate that all longitudinal experiments were performed under the same conditions, each sample was relativized to the internal control. 


\subsubsection{GA has no effect on the CD40 expression on B cells}

The expression of CD40 on B cells was unaffected during GA therapy in both the crosssectional and longitudinal experiments.
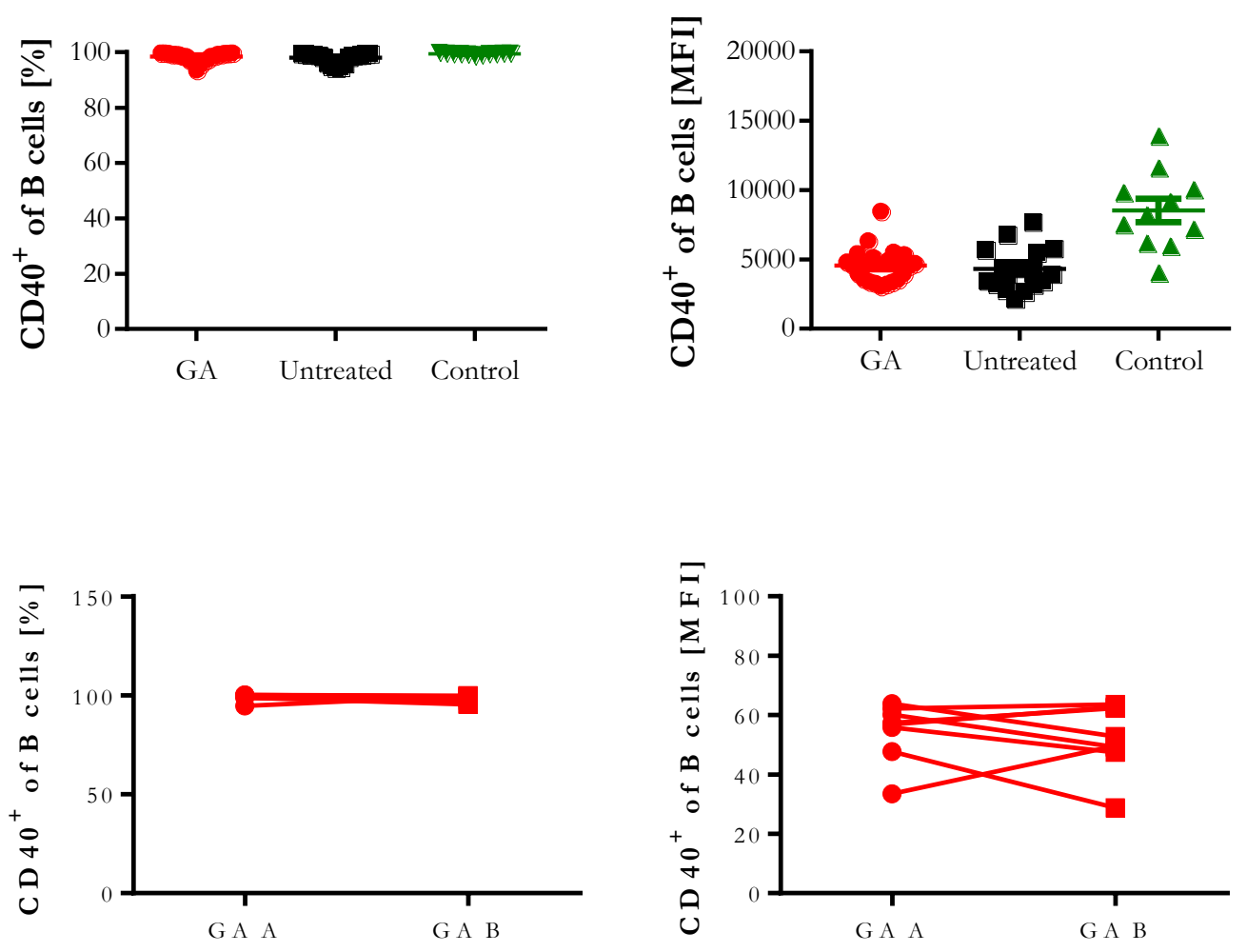

Figure 14: $\mathrm{CD} 40^{+} \mathrm{B}$ cells $[\%$ of $\mathrm{B}$ cells].

The upper graphs show individual patient data in MFI (upper right) and percentage of B cells (upper left) in cross-sectional experiments, $n=22(G A) ; n=18$ (untreated). Mean \pm SEM is represented by whiskers. Lower graphs demonstrate the expression of CD40 on B cells in the longitudinal analyses of blood samples of GA-treated RRMS patients in MFI (lower right) and percentage of B cells (lower left), $n=8$ (GA sample A and GA sample B). In order to demonstrate that all longitudinal experiments were performed under the same conditions, each sample was relativized to the internal control.

\subsubsection{GA reduces the expression of $\mathrm{CD} 69$ on stimulated B cells}

There was a significant reduction of CD69 expression on B cells when the blood samples of GA-treated RRMS patients were analyzed in a longitudinal manner. However, no differences were observed when the blood samples of GA-treated patients were compared to their untreated controls. 

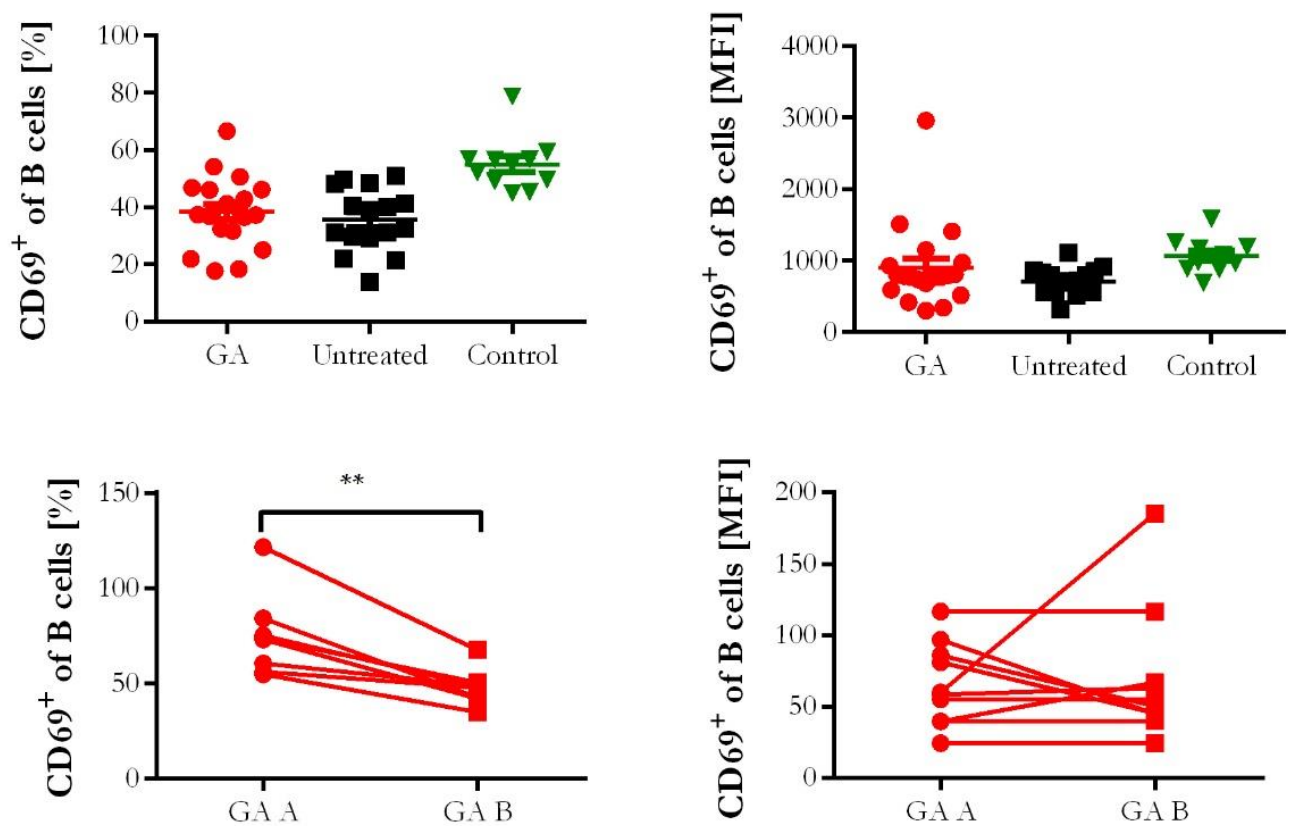

Figure 15: $\mathrm{CD} 69^{+} \mathrm{B}$ cells $[\%$ of $\mathrm{B}$ cells].

There were no significant changes in expression of CD69 on the surface of B cells in the crosssectional samples. The upper graphs show individual patient data in MFI (upper right) and percentage of $B$ cells (upper left) in cross-sectional experiments, $n=22$ (GA); $n=18$ (untreated). Mean \pm SEM is represented by whiskers. Lower graphs demonstrate the downregulation of CD69 expression on $B$ cells in the longitudinal analyses of blood samples of GA-treated RRMS patients in MFI (lower right) and percentage of $B$ cells (lower left), $\mathrm{n}=8$ (GA sample $A$ and GA sample $B),(* *=p<0.01$; Mann Whitney test). In order to demonstrate that all longitudinal experiments were performed under the same conditions, each sample was relativized to the internal control.

\subsubsection{GA has no effect on the CD80 expression on B cells}

The expression of CD80 on B cells was unaffected during GA therapy in both the crosssectional and longitudinal experiments. 

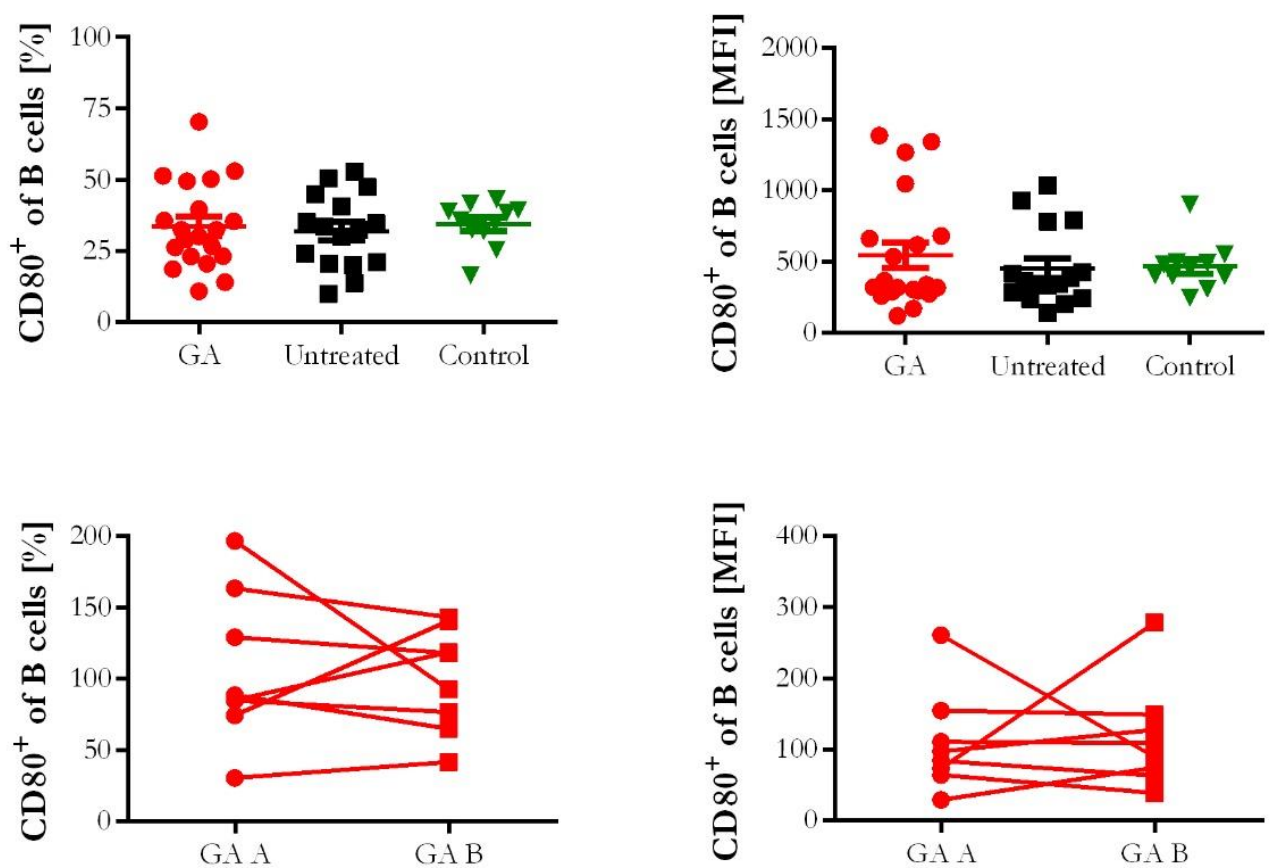

Figure 16: $\mathrm{CD} 80^{+} \mathrm{B}$ cells $[\%$ of $\mathrm{B}$ cells].

The upper graphs show individual patient data in MFI (upper right) and percentage of B cells (upper left) in cross-sectional experiments, $n=22$ (GA); $n=18$ (untreated). Mean \pm SEM is represented by whiskers. Lower graphs demonstrate the expression of CD80 on B cells in the longitudinal analyses of blood samples of GA-treated RRMS patients in MFI (lower right) and percentage of B cells (lower left), $n=8$ (GA sample A and GA sample B). In order to demonstrate that all longitudinal experiments were performed under the same conditions, each sample was relativized to the internal control.

\subsubsection{GA has no effect on the CD86 expression on B cells}

There was no significant difference in the expression of CD86 on B cells in GA-treated patients compared to their untreated controls. Additonally, no significant differences were observed in the longitudinal experiments. 

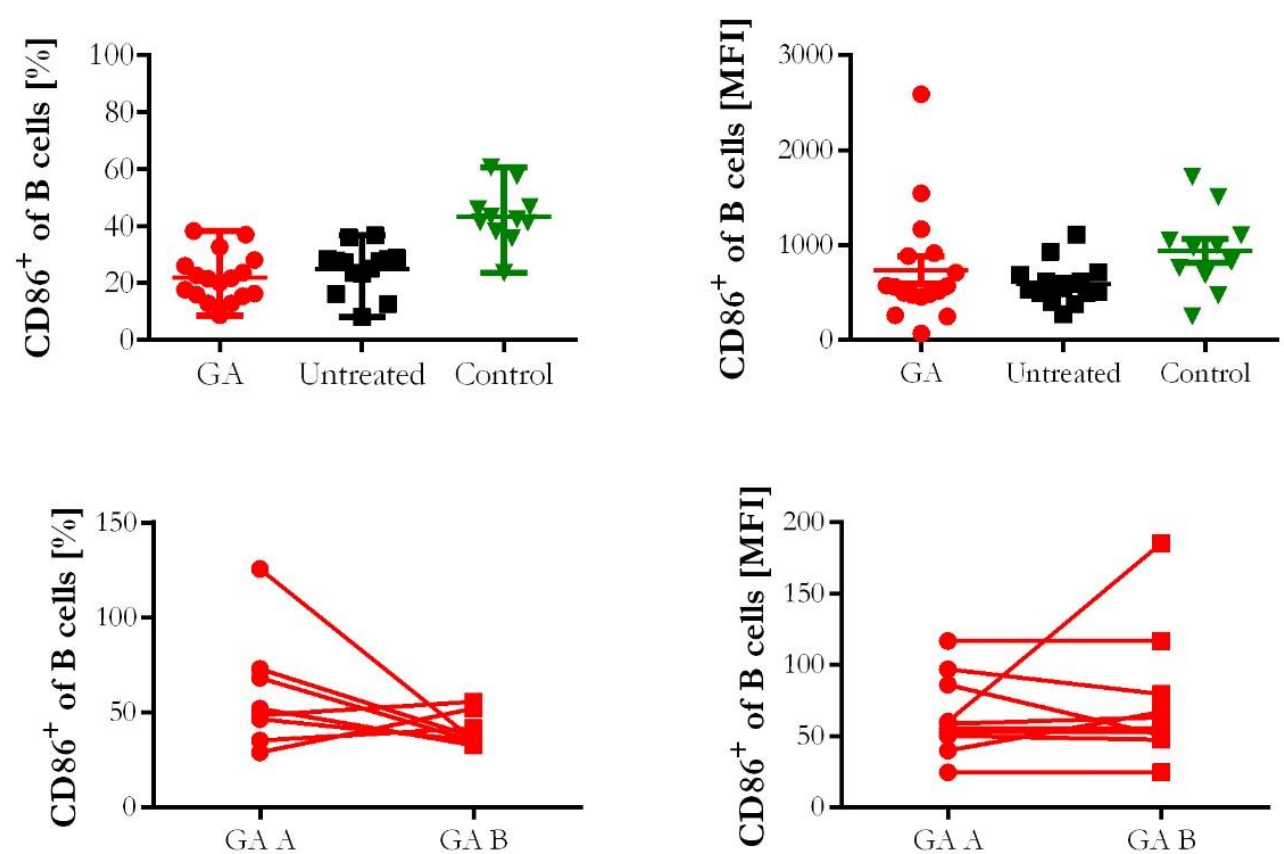

Figure 17: $\mathrm{CD} 86^{+} \mathrm{B}$ cells $[\%$ of $\mathrm{B}$ cells].

The upper graphs show individual patient data in MFI (upper right) and percentage of B cells (upper left) in cross-sectional experiments, $n=22$ (GA); $n=18$ (untreated). Mean \pm SEM is represented by whiskers. Lower graphs demonstrate the expression of CD86 on B cells in the longitudinal analyses of blood samples of GAtreated RRMS patients in MFI (lower right) and percentage of B cells (lower left), $\mathrm{n}=8$ (GA sample A and GA sample B). In order to demonstrate that all longitudinal experiments were performed under the same conditions, each sample was relativized to the internal control.

\subsubsection{The expression of CD95 on B cells positively correlates with GA treatment duration}

The expression of the FAS receptor CD95 on B cells was not affected by GA therapy in both the cross-sectional and longitudinal analyses. However, a positive correlation between the frequency of $\mathrm{CD} 95^{+} \mathrm{B}$ cells and GA treatment duration could be observed. 

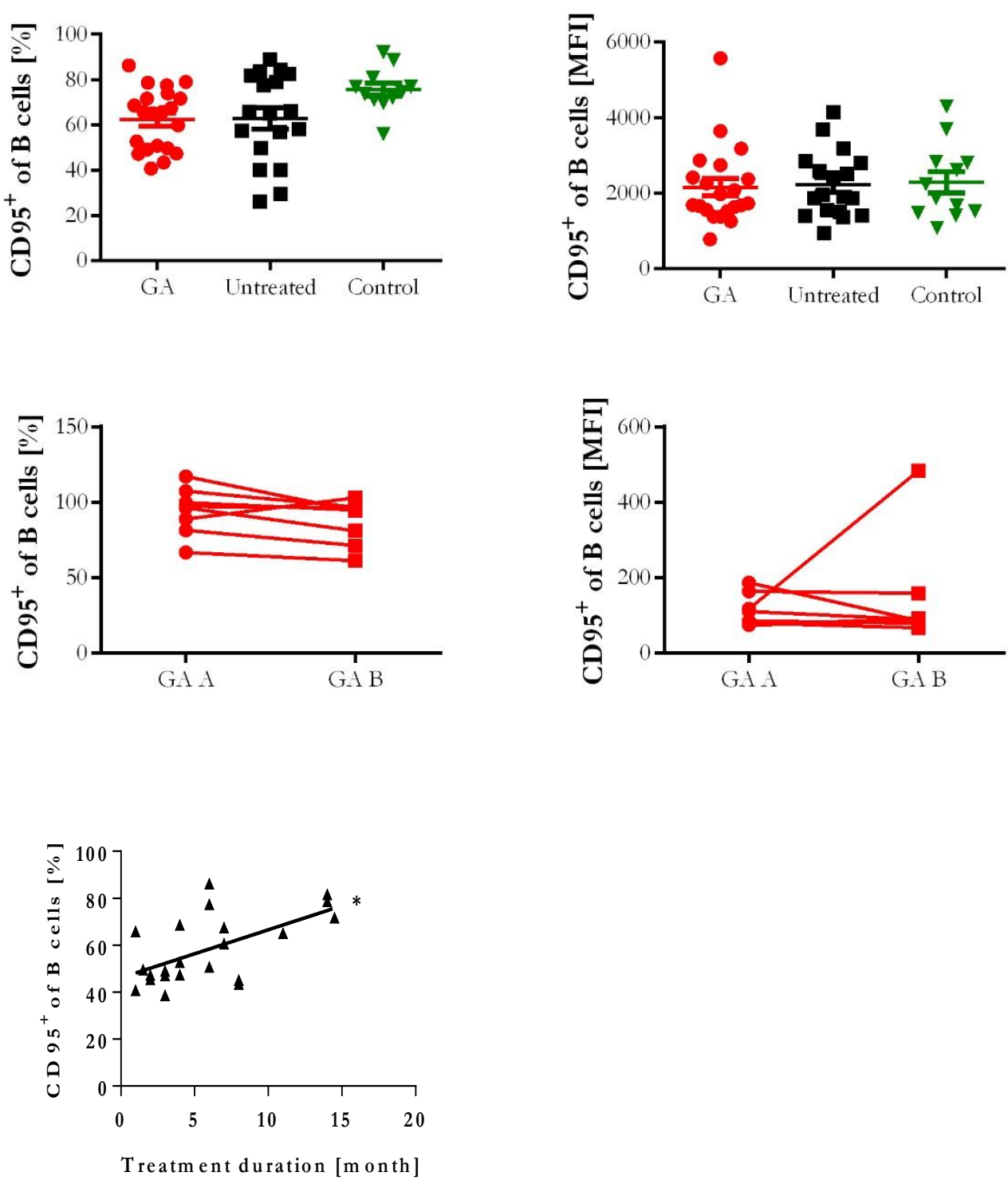

Figure 18: $\mathrm{CD} 95^{+} \mathrm{B}$ cells $[\%$ of $\mathrm{B}$ cells]

The upper graphs show individual patient data in MFI (upper right) and percentage of B cells (upper left) in cross-sectional experiments, $n=22(\mathrm{GA}) ; \mathrm{n}=18$ (untreated). Mean \pm SEM is represented by whiskers. Lower graphs demonstrate the expression of $\mathrm{CD} 95$ on $\mathrm{B}$ cells in the longitudinal analyses of blood samples of GA-treated RRMS patients in MFI (lower right) and percentage of B cells (lower left), $\mathrm{n}=8$ (GA sample A and GA sample B). In order to demonstrate that all longitudinal experiments were performed under the same conditions, each sample was relativized to the internal control. The left lowest graph shows the amount of $\mathrm{CD} 95^{+} \mathrm{B}$ cells in relation to GA treatment duration. The trend line is based on linear progression. 


\subsubsection{GA upregulates the expression of MHC II on B cells}

The expression of MHC II on B cells was significantly higher in GA-treated patients (16705 $\pm 976.5 \mathrm{MFI})$ as compared to their untreated controls (13505 $\pm 1010 \mathrm{MFI})$. There were no significant changes in the expression of MHC II on B cells in the longitudinal experiments.
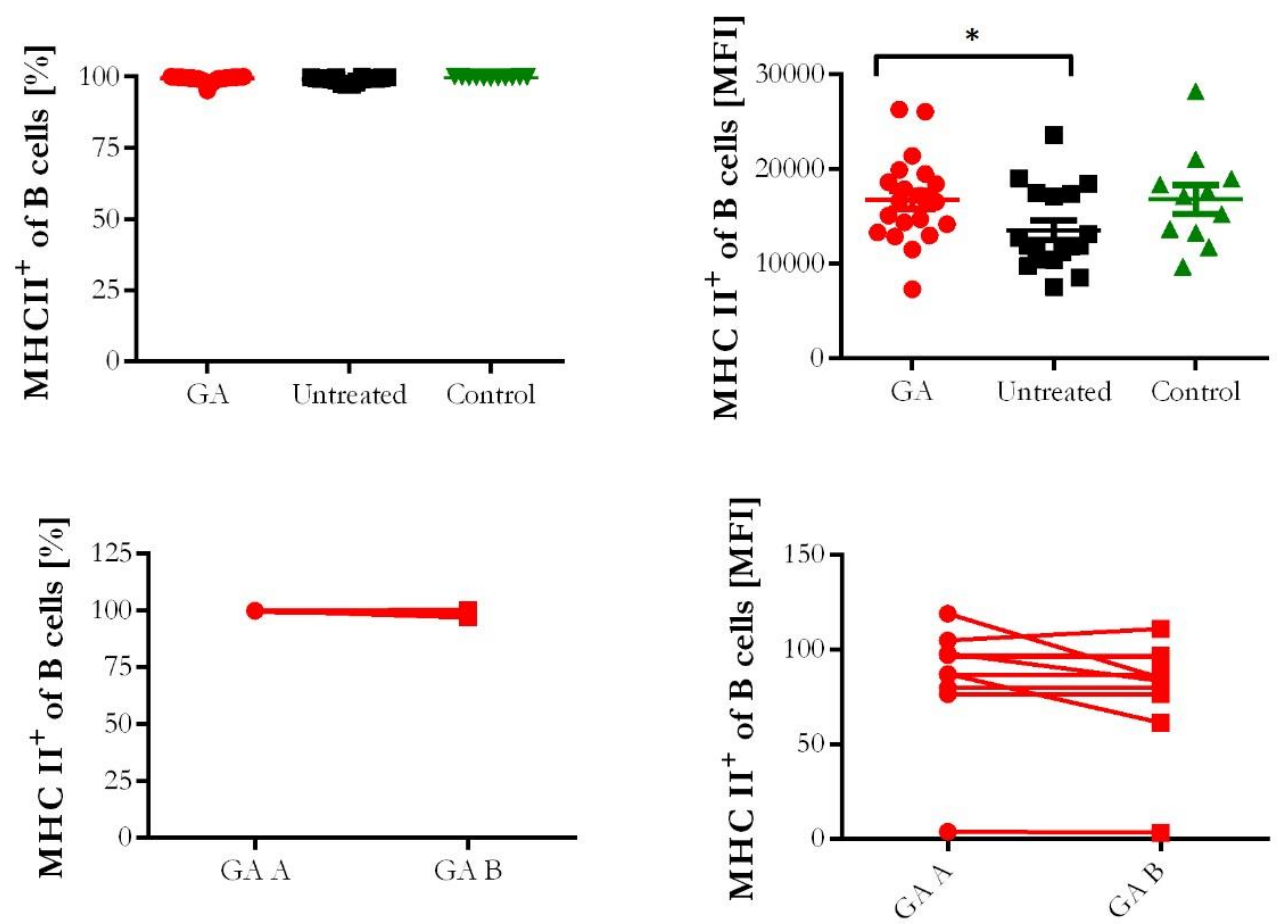

Figure 19: $\mathrm{MHC} \mathrm{II}^{+} \mathrm{B}$ cells $[\%$ of $\mathrm{B}$ cells].

There were no significant changes in the expression of MHC II on B cells in the longitudinal experiments. The upper graphs show individual patient data in MFI (upper right) and percentage of $B$ cells (upper left) in cross-sectional experiment, $n=22$ (GA); $n=18$ (untreated). Mean \pm SEM is represented by whiskers. Lower graphs demonstrate the expression of MHC II on B cells in the longitudinal analyses of blood samples of GA-treated RRMS patients in MFI (lower right) and percentage of B cells (lower left), $n=8$ (GA sample A and GA sample B). In order to demonstrate that all longitudinal experiments were performed under the same conditions, each sample was relativized to the internal control.

\subsubsection{Summary of the GA-induced activation marker changes on B cells}

In summary, there was a significant reduction in the expression of CD25 and CD69 in the longitudinal experiments. Additionally, the expression of MHC II on B cells in GA-treated patients was significantly higher compared to their untreated controls. Furthermore, a positive correlation between the frequency of $\mathrm{CD} 95^{+} \mathrm{B}$ cells and GA treatment duration 
could be observed. For a detailed correlation between the cell surface markers and GA therapy duration, see table 17.
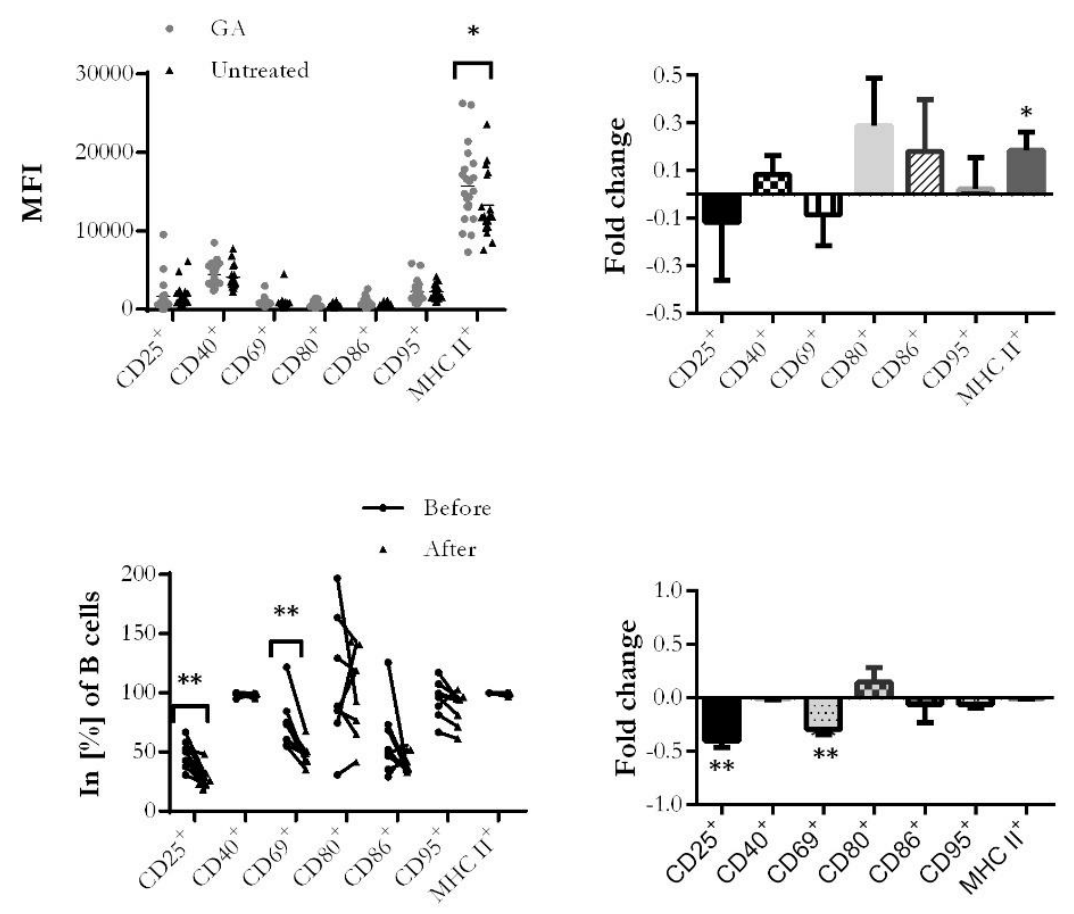

Figure 20: Changes in the expression of activation markers on B cells after GA therapy.

The left upper graph provides a summary of the expression of activation markers on B cells in the cross-sectional samples (MFI). The right upper graph demonstrates relative changes in the expression of activation markers on the surface of B cells in the cross-sectional samples. The left lower graph provides a summary of the expression of activation markers on B cells in the longitudinal samples $(\%)$. The right lower graph demonstrates relative changes in the expression of activation markers on $\mathrm{B}$ cells in the longitudinal samples. There was a significant reduction in the expression of CD25 and CD69 in the longitudinal experiments ( $* *=p<0.01$; Mann Whitney test). However, the expression of MHC II on B cells was higher in GA-treated patients compared to untreated controls in the crosssectional experiments $(*=\mathrm{p}<0.05$; unpaired t-test).

\subsection{Cytokine production}

In order to measure the effect of GA on cytokine production, intracellular staining of proinflammatory (IL- 6 and TNF- $\alpha$ ) and anti-inflammatory (IL-10) cytokines was performed. The cytokine production of B cells (MFI) was quantified by flow cytometry analyses after CpG stimulation. 


\subsubsection{GA has no effect on the IL-6 production in B cells}

The production of IL-6 in B cells was unaffected by GA therapy in both the cross-sectional and longitudinal experiments.
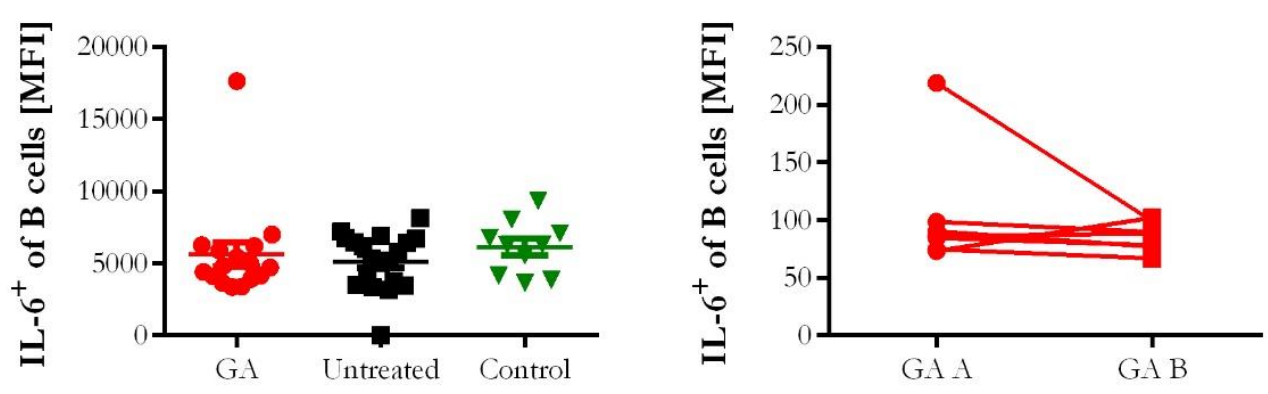

Figure 21: IL-6 production of B cells.

The left graph shows individual patient data in MFI in cross-sectional experiments, $n=16(\mathrm{GA}) ; \mathrm{n}=$ 18 (untreated). Mean \pm SEM is represented by whiskers. The right graph demonstrates the production of IL-6 in B cells in longitudinal analyses of blood samples of GA-treated RRMS patients in MFI, $n=7$ (GA sample A and GA sample B). In order to demonstrate that all longitudinal experiments were performed under the same conditions, each sample was relativized to the internal control.

\subsubsection{GA has no effect on the IL-10 production in B cells}

Both, the cross-sectional and longitudinal analyses of IL-10 secretion by B cells revealed no difference after GA therapy. 

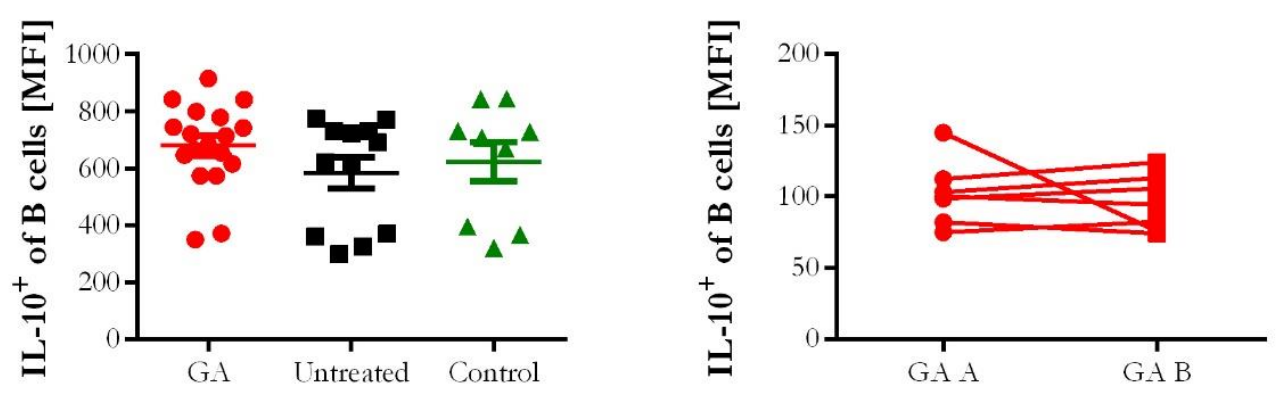

Figure 22: IL-10 production of B cells.

The left graph shows individual patient data in MFI in cross-sectional experiments, $n=18(\mathrm{GA})$; $\mathrm{n}=$ 12 (untreated). Every dot in these plots represents an individual patient, whiskers indicate \pm SEM. The right graph demonstrates the production of IL-10 of B cells in the longitudinal analyses of blood samples of GA-treated RRMS patients in MFI, $n=7$ (GA sample A and GA sample B). In order to demonstrate that all longitudinal experiments were performed under the same conditions, each sample was relativized to the internal control.

\subsubsection{GA downregulates the TNF- $\alpha$ production in B cells}

TNF- $\alpha$, a second major pro-inflammatory cytokine produced by B cells was quantified by flow cytometry. There was a significant reduction in the secretion of TNF- $\alpha$ by B cells under GA therapy in the longitudinal but not in the cross-sectional experiments.
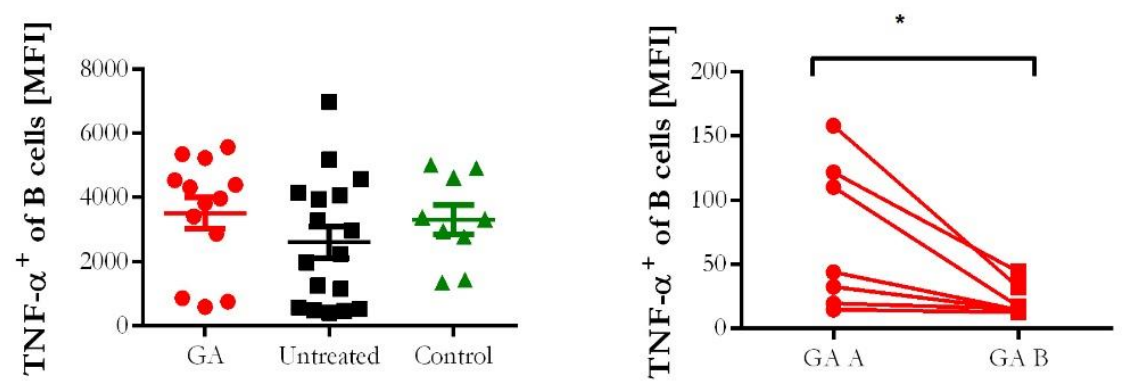

Figure 23: TNF- $\alpha$ production of B cells.

There were no significant changes in the production of TNF- $\alpha$ by B cells when GA-treated patients were compared to untreated RRMS patients in the cross-sectional experiments. The left graph shows individual patient data in MFI in cross-sectional experiments, $n=13$ (GA); $n=16$ (untreated). Mean \pm SEM is represented by whiskers. The right graph demonstrates the reduced production of TNF- $\alpha$ of $B$ cells in the longitudinal analyses of blood samples of GA-treated RRMS patients in MFI, $n=7$ 
(GA sample A and GA sample B), (*= $\mathrm{p}<0.05$; Mann Whitney test). In order to demonstrate that all longitudinal experiments were performed under the same conditions, each sample was relativized to the internal control.

\subsubsection{Summary of the cytokine production upon GA therapy}

In summary, no significant changes in the IL- 6 and IL-10 production of B cells could be observed, in both the cross-sectional and longitudinal analyses. However, the TNF- $\alpha$ production was significantly reduced in the longitudinal experiments. For a detailed correlation between the cytokine production and GA therapy duration, see table 18 . 

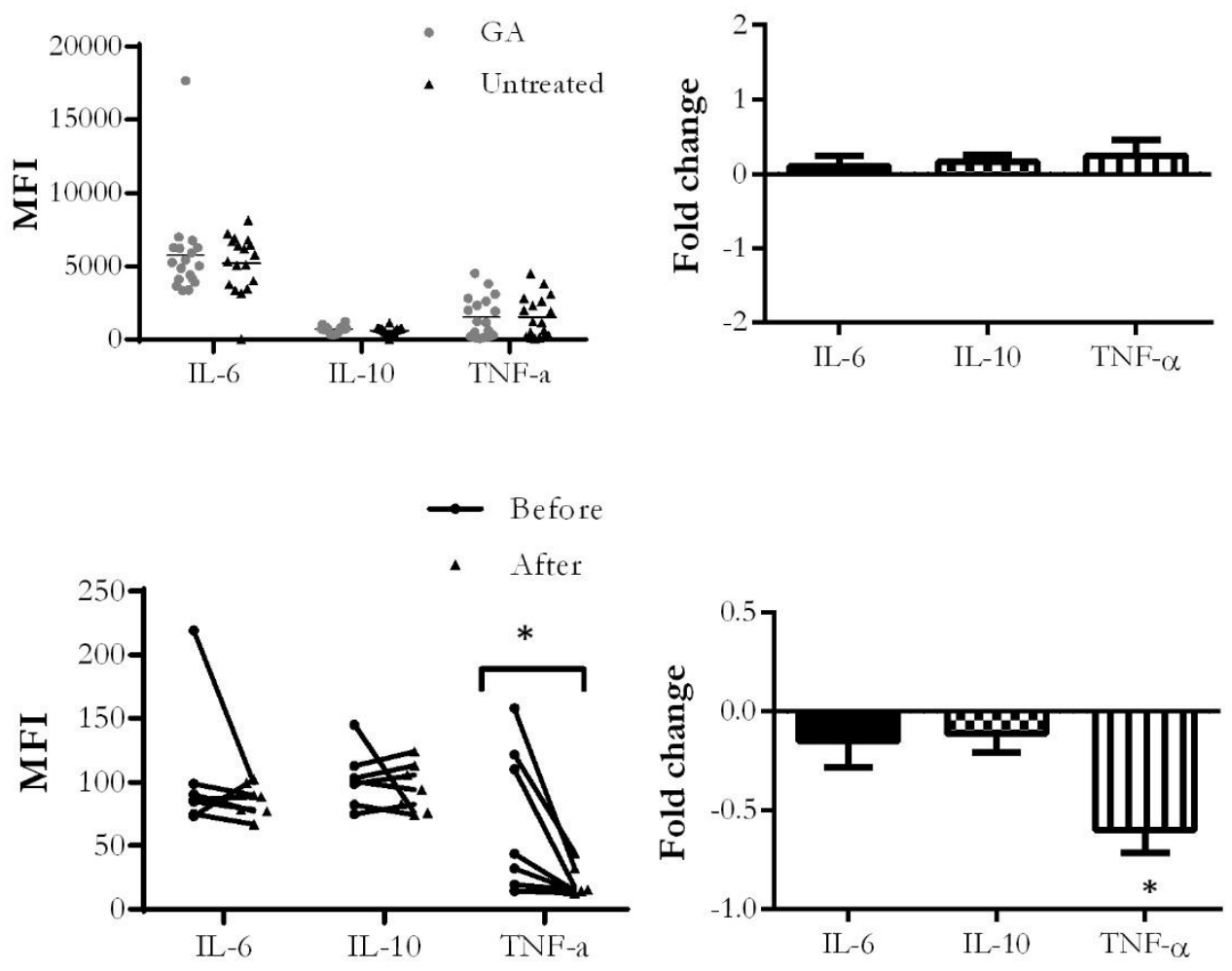

Figure 24: Changes in the B cell cytokine production after GA therapy.

The left graph provides a summary of the cytokine production by B cells in the cross-sectional samples (MFI). The right graph demonstrates the relative changes in cytokine secretion by B cells in the longitudinal data. There was a significant reduction in the production of the important proinflammatory cytokine TNF- $\alpha$ in the longitudinal experiments $(*=p<0.05$; Mann Whitney test).

Table 15: Correlation between cell distribution and therapy duration

\begin{tabular}{|l|l|l|l|l|l|l|}
\hline & Unit & slope (units/month) & $\mathbf{R}^{2}$ & $\mathbf{R}$ & p value & \\
\hline B cells & $\%$ & $-3,576$ & 0,02955 & 0,171901134 & 0,5568 & Ns \\
\hline Monocytes & $\%$ & $-23,3$ & 0,01284 & 0,113313724 & 0,6997 & Ns \\
\hline CD4+ T cells & $\%$ & 5,781 & 0,004213 & 0,064907627 & 0,8255 & Ns \\
\hline CD8+ T cells & $\%$ & 4,161 & 0,01754 & 0,132438665 & 0,6518 & Ns \\
\hline
\end{tabular}


Table 16: Correlation between B cell subsets and GA therapy duration

\begin{tabular}{|l|l|l|l|l|l|l|}
\hline & unit & $\begin{array}{c}\text { slope } \\
\text { (units/month) }\end{array}$ & $\mathbf{R}^{\mathbf{2}}$ & $\mathbf{R}$ & p value \\
\hline $\begin{array}{l}\text { Transitional B } \\
\text { cells }\end{array}$ & $\%$ & $-1,256$ & 0,1906 & 0,4365776 & 0,0543 & Ns \\
\hline Mature & $\%$ & 1,236 & 0,1942 & 0,4406813 & 0,0518 & Ns \\
B cells & $\%$ & 10,95 & 0,001492 & 0,0386264 & 0,8716 & Ns \\
\hline Activated & $\%$ & 1,46 & 0,04099 & 0,2024599 & 0,392 & Ns \\
\hline Bemory & $\%$ & $-20,75$ & 0,01888 & 0,1374045 & 0,5635 & Ns \\
\hline B cells & & & & & & \\
\hline
\end{tabular}


Table 17: Correlation between cell surface markers and GA therapy duration

\begin{tabular}{|c|c|c|c|c|c|c|c|}
\hline & & unit & $\begin{array}{l}\text { Slope } \\
\text { (units/month) }\end{array}$ & $\mathrm{R}^{2}$ & $\mathrm{R}$ & $\mathrm{p}$ value & \\
\hline $\mathrm{CD} 25+\mathrm{B}$ cells & $\begin{array}{l}2 \mu \mathrm{g} / \mathrm{ml} \\
\mathrm{CpG}\end{array}$ & $\%$ & $-5,08$ & 0,0040033 & 0,06327164 & 0,7789 & Ns \\
\hline CD25 on B cells & $\begin{array}{l}2 \mu \mathrm{g} / \mathrm{ml} \\
\mathrm{CpG}\end{array}$ & MFI & $-0,02358$ & 0,007446 & 0,08629021 & 0,4278 & Ns \\
\hline CD $40+B$ cells & $\begin{array}{l}2 \mu \mathrm{g} / \mathrm{ml} \\
\mathrm{CpG}\end{array}$ & $\%$ & 10,01 & 0,07054 & 0,26559367 & 0,2322 & Ns \\
\hline CD40 on B cells & $\begin{array}{l}2 \mu \mathrm{g} / \mathrm{ml} \\
\mathrm{CpG}\end{array}$ & MFI & 0,03122 & 0,008358 & 0,0914221 & 0,6858 & Ns \\
\hline CD69+ B cells & $\begin{array}{l}2 \mu \mathrm{g} / \mathrm{ml} \\
\mathrm{CpG}\end{array}$ & $\%$ & 2,482 & 0,01929 & 0,13888844 & 0,5376 & Ns \\
\hline CD69 on B cells & $\begin{array}{l}2 \mu \mathrm{g} / \mathrm{ml} \\
\mathrm{CpG}\end{array}$ & MFI & 0,0299 & 0,06536 & 0,25565602 & 0,2508 & Ns \\
\hline CD80+ B cells & $\begin{array}{l}2 \mu \mathrm{g} / \mathrm{ml} \\
\mathrm{CpG}\end{array}$ & $\%$ & 1,29 & 0,04126 & 0,20312558 & 0,3646 & Ns \\
\hline CD80 on B cells & $\begin{array}{l}2 \mu \mathrm{g} / \mathrm{ml} \\
\mathrm{CpG}\end{array}$ & MFI & 0,1464 & 0,0057 & 0,07549834 & 0,7384 & Ns \\
\hline $\mathrm{CD} 86+\mathrm{B}$ cells & $\begin{array}{l}2 \mu \mathrm{g} / \mathrm{ml} \\
\mathrm{CpG}\end{array}$ & $\%$ & 6,25 & 0,003956 & 0,06289674 & 0,781 & Ns \\
\hline CD86 on B cells & $\begin{array}{l}2 \mu \mathrm{g} / \mathrm{ml} \\
\mathrm{CpG}\end{array}$ & MFI & 0,04723 & 0,0214 & 0,14628739 & 0,5159 & Ns \\
\hline CD95+ B cells & $\begin{array}{l}2 \mu \mathrm{g} / \mathrm{ml} \\
\mathrm{CpG}\end{array}$ & $\%$ & 0,4892 & 0,3535 & 0,59455866 & 0,0035 & $*$ \\
\hline CD95 on B cells & $\begin{array}{l}2 \mu \mathrm{g} / \mathrm{ml} \\
\mathrm{CpG}\end{array}$ & MFI & 0,0323 & 0,00923 & 0,09607289 & 0,6706 & Ns \\
\hline MHC-II+ B cells & $\begin{array}{l}2 \mu \mathrm{g} / \mathrm{ml} \\
\mathrm{CpG}\end{array}$ & $\%$ & 539,3 & 4,576 & 2,13915871 & 0,9762 & Ns \\
\hline $\begin{array}{l}\text { MHC-II on B } \\
\text { cells }\end{array}$ & $\begin{array}{l}2 \mu \mathrm{g} / \mathrm{ml} \\
\mathrm{CpG}\end{array}$ & MFI & $-0,004156$ & 0,04418 & 0,21019039 & 0,3478 & Ns \\
\hline
\end{tabular}


Table 18: Correlation between cytokine production and GA therapy duration

\begin{tabular}{|l|l|l|l|l|l|l|}
\hline & Unit & slope (units/month) & $\mathbf{R}^{\mathbf{2}}$ & $\mathbf{R}$ & p value & \\
\hline IL-6 in B cells & MFI & $-0,01163$ & 0,01305 & 0,11423659658 & 0,06517 & Ns \\
\hline IL-10 in B cells & MFI & $-0,1085$ & 0,09817 & 0,313320922 & 0,2055 & Ns \\
\hline TNF in B cells & MFI & $-0,005599$ & 0,09801 & 0,313065488 & 0,2059 & Ns \\
\hline
\end{tabular}




\section{Discussion}

\subsection{Cell distribution}

MS is an autoimmune disease of the central nervous system (CNS), and the immune system plays a central role in the disease pathogenesis. Therefore, it is very important to know the cell distribution of the MS patient's PBMC pool. The first part of the present study focuses on the determination of frequency changes of the distinct lymphocyte population.

\subsubsection{B cells}

Historically, MS is thought to be a T cell-mediated disease of the CNS. However, several lines of evidence showed that B cells are also key players in the pathogenesis of MS (Bar-Or et al. 2010; Rawlings et al. 2017; Baker et al. 2017). Major functions of the B cells are cytokine and antibody production and antigen presentation. The most convincing evidence of an important role of B cells in the pathogenesis of MS is the efficacy of anti-CD20 antibody therapy in reducing MS relapses and formation of new lesions in MRI (Moreno Torres and García-Merino 2017). The first aim of the study was to determine if glatiramer acetate changes the total amount of B cells in the PBMC pool. Several investigations showed that the absolute B cell counts diminished in patients taking GA (Teitelbaum et al. 2003; Sean Selva 2014; Ireland et al. 2012). The present study revealed that the B cell frequencies were unchanged when GA-treated patients were compared to untreated MS controls. However, there was a significant reduction of the B cell frequencies with longer GA therapy duration in the longitudinal samples. These findings suggest that the effect of GA therapy on B cells may only occur over time. Additionally to Rituximab, Ocrelizumab, and Ofatumumab, which are B cell-depleting therapeutics, there is evidence that Fingolimod and Mitoxantrone also decrease the total B cell numbers (Longbrake und Cross 2016; Gasperi et al. 2016). Taken together, all these findings demonstrate that the reduction of $\mathrm{B}$ cells is one of the most successful ways to treat RRMS.

\subsection{2 $\mathrm{CD}^{+} \mathrm{T}$ cells}

The most popular theory of the pathogenesis of MS is "molecular mimicry". It means that $\mathrm{CD} 4^{+} \mathrm{T}$ cells activated by a foreign antigen cross-react with myelin antigen (Chitnis 2007). $\mathrm{CD}^{+}{ }^{+} \mathrm{T}$ cells were shown to predominate in acute MS lesions (Raine 1994). In the EAE model, it could be shown that the injection of myelin components leads to a $\mathrm{CD}^{+}{ }^{+} \mathrm{T}$ cellmediated MS-like disease. An adoptive transfer of encephalitogenic $\mathrm{CD}^{+}{ }^{+} \mathrm{T}$ cells into naïve animals caused EAE (Sospedra and Martin 2005). Some investigations showed that the total amount of $\mathrm{CD}^{+}{ }^{+} \mathrm{T}$ cells is reduced in GA-treated patients (Rieks et al. 2003; Kantengwa et 
al. 2007). This study revealed no changes in the $\mathrm{CD}^{+} \mathrm{T}$ cell frequencies in both the crosssectional and longitudinal samples. As the present study focused on B lymphocytes, no further sub-analysis of $\mathrm{CD} 4^{+} \mathrm{T}$ cells was performed.

\subsection{3 $\mathrm{CD}^{+} \mathrm{T}$ cells}

There is evidence that $\mathrm{CD} 4^{+} \mathrm{T}$ cells recognize HLA class II molecules, expressed on macrophages, B cells, dendritic cells, and microglia cells. However, HLA class I molecules can be recognized by $\mathrm{CD}^{+} \mathrm{T}$ cells, which are expressed on all nucleated cells, including oligodendrocytes, astrocytes, and neurons (Hemmer et al. 2015). These findings suggest that $\mathrm{CD}^{+} \mathrm{T}$ cells may directly target these CNS resident cells. It could be demonstrated that in primary culture systems, activated $\mathrm{CD}^{+} \mathrm{T}$ cells injured neuronal axons and oligodendrocytes in an MHC class I-associated manner (Jurewicz et al. 1998; Sauer et al. 2013). Huseby and colleagues demonstrated in a mouse model that $\mathrm{CD}^{+} \mathrm{T}$ cells could cause a severe autoimmune disease of the CNS similar to MS (Huseby et al. 2001). These findings suggest that $\mathrm{CD}^{+} \mathrm{T}$ cells could play an important role as effector cells in the pathogenesis of MS.

There is evidence that untreated MS patients have an increased level of $\mathrm{CD} 8^{+} \mathrm{T}$ cells (Dooley et al. 2016). It was shown that GA is not able to suppress EAE in $C D 8^{+} \mathrm{T}$ cell-deficient mice, which brought the authors to the conclusion that $\mathrm{CD} 8^{+} \mathrm{T}$ cells are very important for the therapeutic effect of glatiramer acetate (Tyler et al. 2013). In the present study, there were no significant changes in the $\mathrm{CD}^{+} \mathrm{T}$ cell frequencies both after $\mathrm{GA}$ therapy as compared to MS controls and in the longitudinal analyses of GA samples. In 2013, Ayers et al. showed an increased level of $\mathrm{CD}^{+} \mathrm{T}$ cells in the peripheral blood of MS patients after 12 hours of GA administration. However, these changes in $\mathrm{CD}^{+} \mathrm{T}$ cell numbers and suppressive abilities at 24 and $72 \mathrm{~h}$ were not statistically different from baseline (Ayers et al. 2013). It can be concluded that the suppressive effect of GA on $\mathrm{CD}^{+} \mathrm{T}$ cells seems to peak at the $12 \mathrm{~h}$ time point. As the present study primarily focused on $\mathrm{B}$ cells, no further analysis of $\mathrm{T}$ cell subsets was performed.

\subsubsection{Monocytes}

CD14 is a myeloid differentiation marker, which is found on the surface of monocytes and macrophages. A low concentration of CD14 can also be found on neutrophils (Shive et al. 2015). It is known that the CD $14^{+}$monocytes circulate in the blood and differentiate into macrophages upon tissue entry. $\mathrm{CD} 14^{+}$monocytes are mainly stored in red pulp of the spleen. Swirski and colleagues demonstrated for the first time that these monocytes may play a direct role in inflammatory processes even before their transformation into macrophages (Swirski et al. 2009). Several investigations demonstrated that CD14-deficient mice showed increased disease severity and infiltration of inflammatory immune cells in EAE (Halmer et 
al. 2015; Walter et al. 2006). There is evidence that monocyte-derived macrophages can produce neuroprotective and anti-inflammatory cytokines (Miron et al. 2013; Shechter et al. 2013). However, they can also worsen neuroinflammation, leading to secondary neurodegeneration (Polfliet et al. 2002). Taken together, these findings suggest that monocytes and macrophages play a dual role in the pathogenesis of multiple sclerosis: proinflammatory and anti-inflammatory. The main roles of monocytes in the pathogenesis of multiple sclerosis are antigen-presentation, cytokine-production, and phagocytosis (Walter et al. 2006). In the present study monocyte frequencies and monocyte functions were analyzed. No significant changes were observed in the total frequency of monocytes within the PBMC pool after GA therapy as compared to MS controls. There was also no significant modulation of the $\mathrm{CD}_{14}{ }^{+}$monocyte function during GA treatment. The present findings are in line with results published by Ayers and colleagues, who showed that the total amount of monocytes in peripheral blood stayed unchanged in GA-treated patients compared to untreated- or healthy controls (Ayers et al. 2013).

\subsubsection{Conclusion: cell distribution}

Not all cell subtypes within the PBMC pool seem to be equally affected after glatiramer acetate therapy. The present study showed that the B cell frequencies were significantly reduced under GA therapy over time. Other cell types such as $\mathrm{CD}^{+}$or $\mathrm{CD} 4^{+} \mathrm{T}$ cells and monocytes seem to be unaffected by glatiramer acetate. These findings are in line with the findings of other studies. There is only one investigation that measured the changes in all these cell types at the same time (Carrieri et al. 2015). As B-cell-depleting agents show growing efficacy in MS treatment, the fact that GA causes a significant reduction in the total amount of B cells over time is very important. Thus, it demonstrates the therapeutic efficacy of GA.

\subsection{Cell survival}

There is evidence that GA suppresses the expression of B cell surviving factors such as BAFF and a proliferation-inducing ligand (APRIL), potentially leading to reduced B cell survival and increased apoptosis and necrosis (Begum-Haque et al. 2010; Dooley et al. 2016). Apoptosis is a programmed cell death, which is regulated and triggered by several cascades. There is a consideration that a dysregulation between apoptotic (Bcl-2, FLIP) and antiapoptotic (CD95) molecules may contribute to disease activity in multiple sclerosis (Seidi and Sharief 2002). In the present study, size exclusion was used to determine apoptotic cells while a Zombie dye stained for necrotic cells. The obtained results revealed a significant reduction of B cells in the longitudinal samples, as described above. The expression of FAS-receptor 
(CD95), which causes apoptosis upon ligand binding, was unaffected when GA-treated MS patients were compared to untreated controls. However, a positive correlation between the frequency of $\mathrm{CD}^{+} 5^{+} \mathrm{B}$ cells and GA treatment duration could be observed. The results indicate that glatiramer acetate affects the apoptosis of cells over time. These findings could explain a significant reduction of B cells in the longitudinal samples, as described above. The exact mechanism of action of GA on the apoptosis of cells remains unclear. There are no similar investigations, demonstrating the role of FAS-receptor (CD95) in the pathogenesis of MS after GA therapy.

\subsection{B cell subsets}

As discussed above, B cells play an important role in the pathogenesis of multiple sclerosis. Therefore, it is important to detect possible effects of GA therapy on B cells. The aim of this study was to evaluate the impact of GA therapy on B cells. In the second part of the study, the impact of GA therapy on B cell differentiation and B cell function was analyzed.

\subsubsection{Transitional B cells}

The initial development of B cells takes place in the bone marrow. First, the immature B cells have to generate a functional B-cell receptor (BCR) and then overcome a negative selection for the reactivity with autoantigens. B cells, which survive these processes in the bone marrow, transit to the spleen to finish their maturation. These immature B cells found in the peripheral blood are called "transitional B cells". Thus, transitional B cells represent a bridge in the development of B cells in the spleen and bone marrow, see for review (Sims 2005). According to $\mathrm{B}$ cell studies in literature, transitional $\mathrm{B}$ cells are defined as CD24 ${ }^{\text {high }} \mathrm{CD} 27^{\text {neg }} \mathrm{CD} 38^{\text {high }}$ (Sims et al. 2005; Hamilton et al. 2017). Unfortunately, there are no studies showing how the total amount of transitional B cells changes under GA therapy. However, a significant reduction in transitional B cell numbers could be demonstrated in Fingolimod and Natalizumab treated MS patients (Haas et al. 2011; Chiarini et al. 2015). The current study showed a significant decrease in transitional B cells with longer ongoing therapy duration. There is evidence that the serum concentration of the B-cell activating factor of the tumor necrosis factor family (BAFF) positively correlates with the proportions and absolute count of transitional B cells (Miyazaki et al. 2018). Several studies demonstrated that GA therapy down-regulates the expression of BAFF (Dooley et al. 2016; Begum-Haque et al. 2010). Taken together, these findings could explain the significant reduction of transitional B cells under GA therapy through the down-regulation of BAFF expression. The current results point toward a decreased output of $\mathrm{B}$ cells from the bone marrow. 


\subsubsection{Mature B cells (naïve B cells)}

As mature $B$ cells express the maturation markers on their surface, they are defined as $\mathrm{CD} 24^{\text {high }} \mathrm{CD} 38^{\text {low }} \mathrm{B}$ cells. Mature or naïve $\mathrm{B}$ cells is the next stage of maturation of transitional B cells but not yet plasmablasts. Several studies described an elevation of naïve B cell numbers in MS patients treated with GA (Haas et al. 2011; Ireland et al. 2014; Rovituso et al. 2014). Additionally, there are studies, which demonstrate similar effects under the therapy with Fingolimod and Natalizumab (Skarica et al. 2011; Claes et al. 2014). In the current study, no significant changes in mature B cell frequencies under GA therapy could be found in both the cross-sectional and longitudinal analyses. As the changes observed in longitudinal samples tended to positively correlate with longer ongoing treatment duration, the results indicate that glatiramer acetate affects the mature B cells over time, in correlation with therapy duration. Taken together, these findings suggest that GA therapy shifts the B cell population toward less disease-promoting B cell subtypes.

\subsubsection{Activated B cells}

In the germinal center, naïve B cells interact with $\mathrm{CD} 4^{+} \mathrm{T}$ cells via MHC II on their surface, presenting their specific antigen. This interaction leads to the activation and proliferation of $\mathrm{B}$ cells. This process results in an upregulation of several activation markers on the surface of B lymphocytes. $\mathrm{CD} 27^{+} \mathrm{B}$ cells were defined as activated B cells in this study. Activated B cells become short-living plasma cells or memory cells, after their clonal expansion in the germinal center (Hamel et al. 2012; Zhang et al. 2016). In the present study, there were no significant changes in the total amount of activated B cells in GA-treated patients as compared to untreated MS controls as well as in the percentage of activated B cells under GA therapy over time.

\subsubsection{Memory B cells}

There is growing evidence that memory B cells play a crucial role in the pathogenesis of MS. These cells are formed in the germinal center after naïve B cells interact with an antigen and undergo activation, proliferation and clonal expansion. In case of re-infection, memory $\mathrm{B}$ cells generate a more effective and accelerated antibody-mediated response (Airoldi et al. 2004). In the current study, memory $B$ cells were defined as $C D 27^{\text {var }} \mathrm{CD} 38^{\text {neg }}$ cells. This gating strategy was also used in most other studies, investigating the role of memory B cells (Li et al. 2017). Recent studies suggest that memory B cells may be a major trigger for relapses in multiple sclerosis. It was found that current MS-treatments such a beta-interferons, rituximab/ocrelizumab, dimethyl fumarate, fingolimod or cladribine deplete memory B cells. Glatiramer acetate was shown to reduce the total amount of memory B cells (Bose 2017; Baker et al. 2017). In the current study, there were no significant changes in the percentage 
of memory B cells in GA-treated patients neither compared to untreated MS patients nor over time under GA therapy.

\subsubsection{Plasmablasts}

Plasmablasts are precursors of antibody-producing plasma cells. Their development usually occurs in the blood. After 2-3 weeks, they either undergo apoptosis or differentiate into plasma cells. Although they can also produce antibodies, it is not as much as plasma cells do. Increased plasmablast numbers in blood are an indication for an active B cell response (Rivas et al. 2017). In MS patients the presence of plasmablasts is associated with an antibodymediated pathology (Nakamura et al. 2015). It could be demonstrated that the frequency of plasmablasts correlated with MS activity according to MRI findings. In the blood of patients having their first clinical attack, plasmablast frequency was also elevated (Ligocki et al. 2013). Additionally, Rivas and colleagues could demonstrate for the first time that plasmablasts in the blood of untreated MS patients show high reactivity for proteins and cellular targets in the brain (Rivas et al. 2017).

GA was shown to reduce the total amount of plasmablasts within the PBMC pool (Ireland et al. 2014). The current findings are in line with these results. The frequency of plasmablasts was significantly reduced in GA-treated RRMS patients as compared to untreated MS controls as well as in the longitudinal GA therapy analyses. As it is considered that the amount of plasmablasts correlates with continuous antibody-mediated destruction and inflammation of the CNS (Avery et al. 2003; Kuerten et al. 2018), the present findings show that GA may prevent the antibody-associated destruction of myelin.

\subsection{B cell activation}

After the interaction of $\mathrm{B}$ cells with $\mathrm{CD}^{+}{ }^{+} \mathrm{T}$ cells, $\mathrm{B}$ cells become activated and there is an upregulation of specific surface molecules. These surface molecules are called activation markers. Although activated B cells play an important role in the pathophysiology of multiple sclerosis, the effect of GA on the surface proteins of activated B cells is poorly investigated. Kala and colleagues observed reduced expression of CD80 and CD86 in GA-treated EAE mice (Kala et al. 2010). Another study demonstrated the reduced expression of CD40 molecules on the surface of B cells under GA therapy in humans (Chen et al. 2016).

In the current study, eight activation markers were included and directly analyzed ex vivo or after restimulation with CPG or LPS. CD40, CD80 and CD86 are representing specific costimulatory activation, whereas CD25, CD27, CD69, CD95 and CD150 are demonstrating an unspecific activation. No significant changes in expression of all parameters were observed in GA-treated patients as compared to untreated RRMS controls. However, the 
expression of CD25 and CD69 was significantly downregulated in the longitudinal analyses of GA-treated patients.

$\mathrm{CD} 25$ is an $\alpha$-chain of the IL-2 receptor. CD25 $5^{+} \mathrm{B}$ cells were shown to trigger $\mathrm{CD} 4^{+} \mathrm{T}$ cell proliferation in mixed cultures. Furthermore, $\mathrm{CD} 25^{+} \mathrm{B}$ cells represent a more activated and mature stage compared to CD25-B cells (Amu et al. 2007). Brisslert and colleagues suggested that $\mathrm{CD} 25^{+} \mathrm{B}$ cells could contribute to antigen-presenting functions and could play a role in bridging innate and acquired immune responses. As a blockade of CD25 expression on $\mathrm{B}$ cells leads to disturbances in T cell activation, it was considered that $\mathrm{CD} 25^{+} \mathrm{B}$ cells play a major role in T cell activation (Brisslert et al. 2006; Amu et al. 2006). Furthermore, it could be demonstrated that in patients with rheumatoid arthritis the $\mathrm{CD} 25^{+} \mathrm{B}$ cells were enriched with EBV and might be an important source of this virus (Brisslert et al. 2013). As EBV may be involved in the pathogenesis of MS (Rizzo et al. 2016; Fernández-Menéndez et al. 2016; Guan et al. 2019), a downregulation of CD $25^{+}$B cells could be an advantageous effect of GA therapy.

Dendritic cells are antigen-presenting cells, which play a crucial role in the innate immune system. Several studies demonstrated that dendritic cells play an important role in the pathogenesis of multiple sclerosis (Weber et al. 2004; Swirski et al. 2009; Kala et al. 2010). There is evidence that $\mathrm{B}$-cell induced activation of dendritic cells depends on the expression of CD69 on the surface of B cells (Maddur et al. 2014).

Taken together, these findings reveal an anti-inflammatory effect of GA-therapy, including the downregulation of CD25 and CD69, which was not discussed in the literature before.

\subsection{Antigen-presenting functions of $\mathrm{B}$ cells}

B cells are potent antigen-presenting cells (APCs). In particular, B cells are able to specifically bind antigens through their B cell receptor (BCR) and induce antigen-specific activation of $T$ cells through the presentation of antigens. Several studies point out that B cells may play their crucial role in the pathogenesis of MS through their antigen-presenting role (Ireland et al. 2012; Bakshi et al. 2013; Sellner et al. 2013; Rovituso et al. 2015). B cells are able to perform their antigen-presenting function only in a complex with the major histocompatibility complex MHC II on their surface. Jackson and colleagues could demonstrate direct binding of GA to the $\mathrm{B}$ cells receptor (BCR) of murine and human $\mathrm{B}$ cells (Sean Selva 2014). There is evidence that the interaction of GA with the BCR may be a central mechanism of action of this drug. It could be demonstrated that the efficacy of GA therapy was abolished in mice with transgenic BCRs (Sean Selva 2014).

In the present study, there was a significant upregulation of MHC II expression on the surface of B cells in GA-treated patients compared with untreated RRMS controls after CpG restimulation. The present finding is in line with other studies showing that GA leads to the 
clustering of MHC II molecules on the surface of B cells (Fridkis-Hareli et al. 1997). However, no significant changes were observed in MHC II expression on B cells in the longitudinal samples. Furthermore, there was a trend after stimulation with LPS, as 5 of 4 GA-treated patients showed a reduced expression of MHC II on the surface of monocytes compared to untreated controls. These findings are in line with the results of $\mathrm{Li}$ and colleagues, demonstrating a down-regulation of the expression of MHC II molecules on monocytes upon GA therapy (Li et al. 1998).

Taken together, these results suggest that the major targets of glatiramer acetate are the antigen-presenting function of B cells and the regulation of the activation of other APCs through B cells. In fact, these findings are in line with other investigations demonstrating that GA inhibits the activation of antigen-presenting cells (Weber et al. 2004; Sellner et al. 2013; Carrieri et al. 2015).

\subsection{Cytokine production}

There is evidence that B cells may play their crucial role in the pathogenesis of multiple sclerosis through their cytokine production (Bar-Or et al. 2010; Sean Selva 2014; Claes et al. 2015). Some studies show that therapy with glatiramer acetate causes a shift toward more anti-inflammatory cytokine production in B cells (Begum-Haque et al. 2010; Begum-Haque et al. 2011; Ireland et al. 2012; Sean Selva 2014).

Interleukin 6 is a pro-inflammatory cytokine and plays an important role in the pathogenesis of multiple sclerosis, as it leads to an increased differentiation of inflammatory Th17 cells (Li et al. 2017). Furthermore, it was shown that the production of IL-6 contributes to functional hyperactivity in APCs (Ireland et al. 2015). Several studies showed that GA reduced the total amount of IL-6 positive B cells (Sean Selva 2014; Ireland et al. 2014). In the present study, there were no significant changes in the frequencies of IL- 6 positive B cells within the PBMC pool upon GA therapy, in both the cross-sectional and longitudinal analyses. It has been considered that suppressed secretion of IL-6 in GA-treated patients is a result of increased IL-10 secretion (Ireland et al. 2015). Since in the current study no significant changes in the IL-10 secretion levels (see below) could be demonstrated, it seems to be expectable that there were also no changes in the IL-6 production. Furthermore, there is evidence that GA therapy causes only a transient reduction in the IL- 6 production of B cells during the first 32 months of therapy following a level indistinguishable to untreated controls at later time points (Ireland et al. 2014). In the present study the mean GA therapy duration was $5.9 \pm 4.1$ months covering early stages of GA modulation, which was possibly before the transient reduction of IL-6 secretion.

Interleukin 10 is an anti-inflammatory cytokine. It plays an important role in the suppression of inflammatory processes in multiple sclerosis. IL-10 inhibits the production of pro- 
inflammatory cytokines such as IL-6, IL-12, IL-18, etc. In-EAE, a selective knockout of IL10 in B cells was associated with severe disease progression (Bar-Or et al. 2010). Kala and colleagues demonstrated that IL-10 produced by B cells downregulated EAE severity. (Kala et al. 2010). In humans several studies showed an increase in IL-10-production in B cells after IFN- $\beta$, glatiramer acetate, fingolimod, and rituximab therapy (Aharoni 2013; Longbrake und Cross 2016). In the current study, no significant changes could be observed in the frequency of IL-10 positive B cells of GA-treated MS patients as compared to MS controls, which is in line with recent findings by Ireland and colleagues (Ireland et al. 2014).

TNF- $\alpha$ is also a pro-inflammatory cytokine and seems to play an important role in the pathogenesis of multiple sclerosis. TNF- $\alpha$ may induce apoptosis, cell proliferation, cell differentiation or production of other cytokines in the immune system. Several studies demonstrated that the frequency of TNF- $\alpha$-positive B cells was diminished in GA-treated patients in comparison to untreated RRMS controls (Begum-Haque et al. 2010; Ayers et al. 2013; Sean Selva 2014). Jackson et al. demonstrated reduced concentrations of TNF- $\alpha$ in 50 $\%$ of GA-treated MS patients compared to untreated controls (Dooley et al. 2016). The findings in humans could be confirmed in EAE mouse models. B cells of GA-treated EAE mice showed reduced production of TNF- $\alpha$ (Begum-Haque et al. 2010; Ireland et al. 2014). The present study revealed decreased frequencies of TNF- $\alpha$ positive B cells in the longitudinal GA therapy analyses. However, no significant changes where observed when GA-treated MS patients were compared to untreated MS controls. Other approved drugs for the therapy of MS, such as fingolimod, dimethyl fumarate, and mitoxantrone were also shown to decrease TNF- $\alpha$ production in B cells (Longbrake and Cross 2016; Li et al. 2017). Taken together, the current findings suggest that GA may diminish inflammatory effects in MS through the reduction of pro-inflammatory cytokine production by B cells. 


\section{$5 \quad$ Summary and Outlook}

Glatiramer acetate was approved for the treatment of RRMS in 1996. It is known to reduce relapse rates and disability progression. In some rare cases, it can cause injection site reaction and in some cases flu-like symptoms. Despite of approval since 1996, the exact mechanism of action of GA is still not clearly understood. Historically, GA has been considered to be a T-cell-targeting therapy. Several investigations of recent years demonstrated that GA affects $\mathrm{B}$ cells. The aim of the current study was to gain a deeper understanding of the effect of GA on functional properties of B cells. To evaluate the effects of GA, flow cytometry (FACS) analysis of peripheral blood mononuclear cells (PBMC) was performed. The samples were obtained from 40 RRMS patients, 22 of which had been treated with GA, and 18 were untreated controls. Both cross-sectional and longitudinal experiments were performed. Four acquisition panels for cell distribution, B cell subsets, activation markers, cytokine production, and antigen presentation were used.

The current study could confirm the huge effect of GA on B cells. The major target of glatiramer acetate seems to be the transitional B cells and plasmablasts. This effect of GA on B cell subsets had been reported before.

Moreover, in the current study, it could be demonstrated that activation markers, such as CD25 and CD69, were significantly reduced in longitudinal experiments under GA therapy. Since there are no studies describing similar effects of GA therapy, the results of the current study might be very important for future therapy strategies of RRMS. Results of Phase II and III clinical trials demonstrated that therapy with Daclizumab, a monoclonal antibody blocking CD25, was very efficient in reducing the relapse rate and T2 hyperintense MRI lesions in RRMS patients compared with placebo and IFN- $\beta$-1a (Papadopoulou et al. 2017). However, in March 2018, Daclizumab was withdrawn from the market after reports of encephalitis. Since then there has actually been no anti-CD25 directed therapy in clinical use. As GA significantly downregulated the expression of CD25 on B cells in the current study, this drug could be used as a follow-up therapy after stabilization of MS patients initially treated with very potent MS drugs with serious side effect profiles.

CD69 is an early activation marker and is involved in lymphocyte migration. Several investigations in mice demonstrated that the anti-CD69 monoclonal antibody treatment had antitumor effects and could potentially be used in the treatment of carcinomas (Esplugues et al. 2003; Wei et al. 2017). There is also evidence that anti-CD69 monoclonal antibodies could have a positive effect on rheumatologic diseases (Sancho et al. 2006). As the current study demonstrated a significant downregulation of CD69 expression on B cells upon GA therapy, it could be considered to choose GA primarily for the treatment of MS patients additionally suffering from cancer or rheumatologic diseases.

In the current study, the expression of MHC II, the most important surface molecule for antigen presentation, on B cells in GA-treated patients was significantly higher in comparison 
to untreated RRMS controls. These findings are not surprising, since it has been suggested that after interaction with the $\mathrm{B}$ cell receptor (BCR), GA is internalized and then presented by MHC II to regulatory $\mathrm{CD} 4^{+} \mathrm{T}$ cells.

The second striking point was the shift to an anti-inflammatory cytokine production in B cells. No changes could be demonstrated in both IL-6 and IL-10 production. As it is known that changes in the cytokine production under therapy may be transient, it is possible that in the current study these transient changes could not yet be determined. However, a significant decrease in TNF- $\alpha$ secretion by B cells in GA-treated patients compared to untreated controls could be demonstrated.

In conclusion, the current study provokes questions that have to be answered in a larger cohort of longitudinal samples. The following aspects may be relevant for future MS treatment: more detailed understanding of the GA effect on antigen presentation, GA as a follow-up therapy after stabilization of MS patients initially treated with very potent MS drugs with serious side effects, use of GA in the treatment of MS patients additionally suffering from cancer or rheumatological diseases, determination of transient changes in cytokine production under GA therapy, and understanding the role of $\mathrm{B}$ cell activation markers in the pathogenesis of MS. 


\section{References}

Aharoni R (2013): The mechanism of action of glatiramer acetate in multiple sclerosis and beyond. Autoimmun Rev 12, 543-553

Aharoni R, Teitelbaum D, Sela M, Arnon R (1998): Bystander suppression of experimental autoimmune encephalomyelitis by $\mathrm{T}$ cell lines and clones of the Th2 type induced by copolymer 1. J Neuroimmunol 91, 135-146

Airoldi I, Raffaghello L, Cocco C, Guglielmino R, Roncella S, Fedeli F, Gambini C, Pistoia V (2004): Heterogeneous expression of interleukin-18 and its receptor in B-cell lymphoproliferative disorders deriving from naive, germinal center, and memory B lymphocytes. Clin Cancer Res 10, 144-154

Akbulak RÖ, Rosenkranz SC, Schaeffer BN, Pinnschmidt HO, Willems S, Heesen C, Hoffmann BA (2018): Acute and long-term effects of fingolimod on heart rhythm and heart rate variability in patients with multiple sclerosis. Mult Scler Relat Disord 19, 44-49

Amu S, Gjertsson I, Tarkowski A, Brisslert M (2006): B-cell CD25 expression in murine primary and secondary lymphoid tissue. Scand J Immunol 64, 482-492

Amu S, Tarkowski A, Dörner T, Bokarewa M, Brisslert M (2007): The human immunomodulatory CD25+ B cell population belongs to the memory B cell pool. Scand J Immunol $\underline{66}, 77-86$

Arnon R (1996): The development of Cop 1 (Copaxone), an innovative drug for the treatment of multiple sclerosis: personal reflections. Immunol Lett $\underline{50}, 1-15$

Aung LL, Balashov KE (2015): Decreased Dicer expression is linked to increased expression of co-stimulatory molecule CD80 on B cells in multiple sclerosis. Mult Scler J 21, $1131-1138$

Avery DT, Kalled SL, Ellyard JI, Ambrose C, Bixler SA, Thien M, Brink R, Mackay F, Hodgkin PD, Tangye SG (2003): BAFF selectively enhances the survival of plasmablasts generated from human memory B cells. J Clin Invest 112, 286-297

Ayers CL, Mendoza JP, Sinha S, Cunnusamy K, Greenberg BM, Frohman EM, Karandikar NJ (2013): Modulation of immune function occurs within hours of therapy initiation for multiple sclerosis. Clin Immunol 147, 105-119 
Baker D, Marta M, Pryce G, Giovannoni G, Schmierer K (2017): Memory B Cells are Major Targets for Effective Immunotherapy in Relapsing Multiple Sclerosis. EBioMedicine 16, 41-50

Bakshi S, Chalifa-Caspi V, Plaschkes I, Perevozkin I, Gurevich M, Schwartz R (2013): Gene expression analysis reveals functional pathways of glatiramer acetate activation. Expert Opin Ther Targets 17, 351-362

Bar-Or A, Fawaz L, Fan B, Darlington PJ, Rieger A, Ghorayeb C, Calabresi PA, Waubant E, Hauser SL, Zhang J, Smith CH (2010): Abnormal B-cell cytokine responses a trigger of T-cell-mediated disease in MS? Ann Neurol 67, 452-461

Basile E, Gibbs E, Aziz T, Oger J (2006): During 3 years treatment of primary progressive multiple sclerosis with glatiramer acetate, specific antibodies switch from IgG1 to IgG4. J Neuroimmunol 177, 161-166

Begum-Haque S, Sharma A, Christy M, Lentini T, Ochoa-Reparaz J, Fayed IF, Mielcarz D, Haque A, Kasper LH (2010): Increased expression of B cell-associated regulatory cytokines by glatiramer acetate in mice with experimental autoimmune encephalomyelitis. J Neuroimmunol 219, 47-53

Begum-Haque S, Christy M, Ochoa-Reparaz J, Nowak EC, Mielcarz D, Haque A, Kasper LH (2011): Augmentation of regulatory B cell activity in experimental allergic encephalomyelitis by glatiramer acetate. J Neuroimmunol 232, 136-144

Berkovich RR (2016): Acute Multiple Sclerosis Relapse. Continnuum 22, 799-814

Biernacki T, Bencsik K, Sandi D, Vécsei L (2017): [Alemtuzumab therapy 2017]. Ideggyogy Sz $\underline{70}, 371-380$

Blauth K, Soltys J, Matschulat A, Reiter CR, Ritchie A, Baird NL, Bennett JL, Owens GP (2015): Antibodies produced by clonally expanded plasma cells in multiple sclerosis cerebrospinal fluid cause demyelination of spinal cord explants. Acta Neuropathol $\underline{130}, 765-781$

Bomprezzi R, Schaefer R, Reese V, Misra A, Vollmer TL, Kala M (2011): Glatiramer AcetateSpecific Antibody Titres in Patients with Relapsing / Remitting Multiple Sclerosis and in Experimental Autoimmune Encephalomyelitis. Scand J Immunol 74, 219-226

Bose T (2017): Role of Immunological Memory Cells as a Therapeutic Target in Multiple Sclerosis. Brain Sci 7, 148 
Brenner T, Arnon R, Sela M, Abramsky O, Meiner Z, Riven-Kreitman R, Tarcik N, Teitelbaum D (2001): Humoral and cellular immune responses to Copolymer 1 in multiple sclerosis patients treated with Copaxone. J Neuroimmunol 115, 152-160

Brisslert M, Bokarewa M, Larsson P, Wing K, Collins LV, Tarkowski A (2006): Phenotypic and functional characterization of human CD25+ B cells. Immunology $117,548-$ 557

Brisslert M, Rehnberg M, Bokarewa MI (2013): Epstein-Barr virus infection transforms $\mathrm{CD} 25+\mathrm{B}$ cells into antibody-secreting cells in rheumatoid arthritis patients. Immunology 140, 421-429

Buttmann M (2018): Where mitoxantrone for multiple sclerosis is still valuable in 2018. Eur J Neurol 25, 1400-1401

Carrieri PB, Carbone F, Perna F, Bruzzese D, La Rocca C, Galgani M, Montella S, Petracca M, Florio C, Maniscalco GT, et al. (2015): Longitudinal assessment of immunometabolic parameters in multiple sclerosis patients during treatment with glatiramer acetate. Metabolism 64, 1112-1121

Chen D, Ireland SJ, Remington G, Alvarez E, Racke MK, Greenberg B, Frohman EM, Monson NL (2016): CD40-mediated NFxB activation in B cells is increased in multiple sclerosis and modulated by therapeutics. J Immunol 197, 4257-4265

Chiarini M, Sottini A, Bertoli D, Serana F, Caimi L, Rasia S, Capra R, Imberti L (2015): Newly produced $\mathrm{T}$ and $\mathrm{B}$ lymphocytes and $\mathrm{T}$-cell receptor repertoire diversity are reduced in peripheral blood of fingolimod-treated multiple sclerosis patients. Mult Scler 21, 726-734

Chihara N, Aranami T, Sato W, Miyazaki Y, Miyake S, Okamoto T, Ogawa M, Toda T, Yamamura T (2011): Interleukin 6 signaling promotes anti-aquaporin 4 autoantibody production from plasmablasts in neuromyelitis optica. Proc Natl Acad Sci U S A $\underline{108}$, 3701-3706

Chitnis T (2007): The Role of CD4 T Cells in the Pathogenesis of Multiple Sclerosis. Int Rev Neurobiol, 79, 43-72

Claes N, Dhaeze T, Fraussen J, Broux B, Van Wijmeersch B, Stinissen P, Hupperts R, Hellings N, Somers V (2014): Compositional changes of B and T cell subtypes during fingolimod treatment in multiple sclerosis patients: a 12-month follow-up study. PloS One $\underline{9}$, e111115 
Claes N, Fraussen J, Stinissen P, Hupperts R, Somers V (2015): B Cells Are Multifunctional Players in Multiple Sclerosis Pathogenesis: Insights from Therapeutic Interventions. Front Immunol 6, 642

Comi G, Martinelli V, Rodegher M, Moiola L, Leocani L, Bajenaru O, Carra A, Elovaara I, Fazekas F, Hartung H-P, et al. (2013): Effects of early treatment with glatiramer acetate in patients with clinically isolated syndrome. Mult Scler 19, 1074-1083

Compston A, Coles A (2002): Multiple sclerosis. Lancet 359, 1221-1231

Compston A, Coles A (2008): Multiple sclerosis. Lancet $\underline{\text { 372, }}$ 1502-1517

Constantinescu C, Gran B (2014): The essential role of t cells in multiple sclerosis: A reappraisal. Biomed J $\underline{37}, 34-40$

Cross AH, Naismith RT (2014): Established and novel disease-modifying treatments in multiple sclerosis. J Intern Med 275, 350-363

Dalakas MC (2008): Invited Article: Inhibition of B cell functions: Implications for neurology. Neurology $\underline{70}$, 2252-2260

De Stefano N, Stromillo ML, Giorgio A, Bartolozzi ML, Battaglini M, Baldini M, Portaccio E, Amato MP, Sormani MP (2015): Establishing pathological cut-offs of brain atrophy rates in multiple sclerosis. J Neurol Neurosurg Psychiatry $\underline{87}$, 93-99

Dooley J, Pauwels I, Franckaert D, Smets I, Garcia-Perez JE, Hilven K, Danso-Abeam D, Terbeek J, Nguyen ATL, De Muynck L, et al. (2016): Immunologic profiles of multiple sclerosis treatments reveal shared early B cell alterations. Neurol Neuroimmunol Neuroinflammation $\underline{3}$, e240

Ehler J, Blechinger S, Rommer PS, Koball S, Mitzner S, Hartung H-P, Leutmezer F, Sauer M, Zettl UK (2017): Treatment of the First Acute Relapse Following Therapeutic Plasma Exchange in Formerly Glucocorticosteroid-Unresponsive Multiple Sclerosis Patients-A Multicenter Study to Evaluate Glucocorticosteroid Responsiveness. Int J Mol Sci $\underline{18}$, E1749

Esplugues E, Sancho D, Vega-Ramos J, Martínez C, Syrbe U, Hamann A, Engel P, SánchezMadrid F, Lauzurica P (2003): Enhanced antitumor immunity in mice deficient in CD69. J Exp Med 197, 1093-1106

Evlice A, Demir T, Kaleağası C, Özcan F, Demirkıran M (2016): Rare onset symptoms in multiple sclerosis. Acta Clin Belg 71, 154-157 
Farina C, Vargas V, Heydari N, Kümpfel T, Meinl E, Hohlfeld R (2002): Treatment with glatiramer acetate induces specific IgG4 antibodies in multiple sclerosis patients. J Neuroimmunol $\underline{123}, 188-192$

Fernández-Menéndez S, Fernández-Morán M, Fernández-Vega I, Pérez-Álvarez A, Villafani-Echazú J (2016): Epstein-Barr virus and multiple sclerosis. From evidence to therapeutic strategies. J Neurol Sci $\underline{361}, 213-219$

Fischer MT, Wimmer I, Höftberger R, Gerlach S, Haider L, Zrzavy T, Hametner S, Mahad D, Binder CJ, Krumbholz M, et al. (2013): Disease-specific molecular events in cortical multiple sclerosis lesions. Brain J Neurol 136, 1799-1815

Ford C, Goodman AD, Johnson K, Kachuck N, Lindsey JW, Lisak R, Luzzio C, Myers L, Panitch H, Preiningerova J, et al. (2010): Continuous long-term immunomodulatory therapy in relapsing multiple sclerosis: results from the 15-year analysis of the US prospective open-label study of glatiramer acetate. Mult Scler 16, 342-350

Franciotta D, Salvetti M, Lolli F, Serafini B, Aloisi F (2008): B cells and multiple sclerosis. Lancet Neurol 7, 852-858

Fridkis-Hareli M, Teitelbaum D, Gurevich E, Pecht I, Brautbar C, Kwon OJ, Brenner T, Arnon R, Sela M (1994): Direct binding of myelin basic protein and synthetic copolymer 1 to class II major histocompatibility complex molecules on living antigen-presenting cells-specificity and promiscuity. Proc Natl Acad Sci U S A $\underline{1}$, 4872-4876

Fridkis-Hareli M, Teitelbaum D, Pecht I, Arnon R, Sela M (1997): Binding of copolymer 1 and myelin basic protein leads to clustering of class II MHC molecules on antigenpresenting cells. Int Immunol $\underline{9}$, 925-934

Frischer JM, Bramow S, Dal-Bianco A, Lucchinetti CF, Rauschka H, Schmidbauer M, Laursen H, Sorensen PS, Lassmann H (2009): The relation between inflammation and neurodegeneration in multiple sclerosis brains. Brain 132, 1175-1189

Gajofatto A (2017): Spotlight on siponimod and its potential in the treatment of secondary progressive multiple sclerosis: the evidence to date. Drug Des Devel Ther $\underline{11}, 3153$ 3157

Gasperi C, Stüve O, Hemmer B (2016): B cell-directed therapies in multiple sclerosis. Neurodegener Dis Manag $\underline{6}, 37-47$

Gelfand JM, Cree BAC, Hauser SL (2017): Ocrelizumab and Other CD20+ B-Cell-Depleting Therapies in Multiple Sclerosis. Neurother J 14, 835-841 
Ghasemi N (2017): Multiple Sclerosis: Pathogenesis, Symptoms, Diagnoses and Cell-Based Therapy. Cell J $\underline{19}, 10$

Grand'Maison F, Yeung M, Morrow SA, Lee L, Emond F, Ward BJ, Laneuville P, Schecter R (2018): Sequencing of high-efficacy disease-modifying therapies in multiple sclerosis: perspectives and approaches. Neural Regen Res 13, 1871-1874

Guan Y, Jakimovski D, Ramanathan M, Weinstock-Guttman B, Zivadinov R (2019): The role of Epstein-Barr virus in multiple sclerosis: from molecular pathophysiology to in vivo imaging. Neural Regen Res 14, 373-386

Haas J, Korporal M, Balint B, Fritzsching B, Schwarz A, Wildemann B (2009): Glatiramer acetate improves regulatory $\mathrm{T}$-cell function by expansion of naive CD4+CD25+FOXP3+CD31+ T-cells in patients with multiple sclerosis. J Neuroimmunol 216, 113-117

Haas J, Bekeredjian-Ding I, Milkova M, Balint B, Schwarz A, Korporal M, Jarius S, Fritz B, Lorenz H-M, Wildemann B (2011): B cells undergo unique compartmentalized redistribution in multiple sclerosis. J Autoimmun 37, 289-299

Halmer R, Davies L, Liu Y, Fassbender K, Walter S (2015): The Innate Immune Receptor CD14 Mediates Lymphocyte Migration in EAE. Cell Physiol Biochem 그, 269-275

Hamel KM, Liarski VM, Clark MR (2012): Germinal center B-cells. Autoimmunity 4도, 333347

Hamilton JA, Wu Q, Yang P, Luo B, Liu S, Hong H, Li J, Walter MR, Fish EN, Hsu H-C, Mountz JD (2017): Cutting Edge: Endogenous IFN- $\beta$ Regulates Survival and Development of Transitional B Cells. J Immunol 199, 2618-2623

Hauser SL, Arnold DL, Fox RJ, Sarkar N, Smith CH (2008): B-Cell Depletion with Rituximab in Relapsing-Remitting Multiple Sclerosis. N Engl J Med 358, 676-688

Hemmer B, Kerschensteiner M, Korn T (2015): Role of the innate and adaptive immune responses in the course of multiple sclerosis. Lancet Neurol 14, 406-419

Henderson APD, Barnett MH, Parratt JDE, Prineas JW (2009): Multiple sclerosis: distribution of inflammatory cells in newly forming lesions. Ann Neurol $\underline{66}, 739-753$

Ho P-R, Koendgen H, Campbell N, Haddock B, Richman S, Chang I (2017): Risk of natalizumab-associated progressive multifocal leukoencephalopathy in patients with multiple sclerosis: a retrospective analysis of data from four clinical studies. Lancet Neurol 16, 925-933 
Huseby ES, Liggitt D, Brabb T, Schnabel B, Ohlén C, Goverman J (2001): A pathogenic role for myelin-specific CD8(+) T cells in a model for multiple sclerosis. J Exp Med 194, 669-676

Hussien Y, Sanna A, Söderström M, Link H, Huang YM (2001): Glatiramer acetate and IFNbeta act on dendritic cells in multiple sclerosis. J Neuroimmunol 121, 102-110

Ireland SJ, Blazek M, Harp CT, Greenberg B, Frohman EM, Davis LS, Monson NL (2012): Antibody-independent B cell effector functions in relapsing remitting Multiple Sclerosis: Clues to increased inflammatory and reduced regulatory B cell capacity. Autoimmunity $\underline{45}, 400-414$

Ireland SJ, Guzman AA, O’Brien DE, Hughes S, Greenberg B, Flores A, Graves D, Remington G, Frohman EM, Davis LS, Monson NL (2014): The Effect of Glatiramer Acetate Therapy on Functional Properties of B Cells From Patients With Relapsing-Remitting Multiple Sclerosis. JAMA Neurol 1ㅡ, 1421

Ireland SJ, Monson NL, Davis LS (2015): Seeking Balance: Potentiation and Inhibition of Multiple Sclerosis Autoimmune Responses by IL-6 and IL-10. Cytokine 73, 236-244

Johnson KP, Brooks BR, Cohen JA, Ford CC, Goldstein J, Lisak RP, Myers LW, Panitch HS, Rose JW, Schiffer RB (1995): Copolymer 1 reduces relapse rate and improves disability in relapsing-remitting multiple sclerosis: results of a phase III multicenter, double-blind placebo-controlled trial. The Copolymer 1 Multiple Sclerosis Study Group. Neurology 4ㄴ, 1268-1276

Jurewicz A, Biddison WE, Antel JP (1998): MHC class I-restricted lysis of human oligodendrocytes by myelin basic protein peptide-specific CD8 T lymphocytes. J Immunol 160, 3056-3059

Kala M, Rhodes SN, Piao W-H, Shi F-D, Campagnolo DI, Vollmer TL (2010): B cells from glatiramer acetate-treated mice suppress experimental autoimmune encephalomyelitis. Exp Neurol 221, 136-145

Kamm CP, Uitdehaag BM, Polman CH (2014): Multiple Sclerosis: Current Knowledge and Future Outlook. Eur Neurol 2, 132-141

Kantengwa S, Weber MS, Juillard C, Benkhoucha M, Fellay B, Zamvil SS, Gougeon M-L, Chofflon M, Lalive PH (2007): Inhibition of naive Th1 CD4+ T cells by glatiramer acetate in multiple sclerosis. J Neuroimmunol $\underline{185}, 123-129$

Karussis D, Teitelbaum D, Sicsic C, Brenner T (2010): Long-term treatment of multiple sclerosis with glatiramer acetate: Natural history of the subtypes of anti-glatiramer 
acetate antibodies and their correlation with clinical efficacy. J Neuroimmunol $\underline{220}$, $125-130$

Krumbholz M, Theil D, Derfuss T, Rosenwald A, Schrader F, Monoranu C-M, Kalled SL, Hess DM, Serafini B, Aloisi F, et al. (2005): BAFF is produced by astrocytes and upregulated in multiple sclerosis lesions and primary central nervous system lymphoma. J Exp Med 201, 195-200

Kuerten S, Jackson LJ, Kaye J, Vollmer TL (2018): Impact of Glatiramer Acetate on B CellMediated Pathogenesis of Multiple Sclerosis. CNS Drugs 32, 1039-1051

Kurtzke JF (2015): On the origin of EDSS. Mult Scler Relat Disord 4, 95-103

Kutzelnigg A, Lucchinetti CF, Stadelmann C, Brück W, Rauschka H, Bergmann M, Schmidbauer M, Parisi JE, Lassmann H (2005): Cortical demyelination and diffuse white matter injury in multiple sclerosis. Brain J Neurol 128, 2705-2712

Lassmann H (2008): Models of multiple sclerosis: new insights into pathophysiology and repair. Curr Opin Neurol 21, 242-247

Lassmann H (2013): Pathology and disease mechanisms in different stages of multiple sclerosis. J Neurol Sci $\underline{333}, 1-4$

Lassmann H, Brück W, Lucchinetti C (2001): Heterogeneity of multiple sclerosis pathogenesis: implications for diagnosis and therapy. Trends Mol Med 7, 115-121

Lessmann V, Gottmann K, Malcangio M (2003): Neurotrophin secretion: current facts and future prospects. Prog Neurobiol $\underline{69}, 341-374$

Li Q, Milo R, Panitch H, Swoveland P, Bever CT (1998): Glatiramer acetate blocks the activation of THP-1 cells by interferon-gamma. Eur J Pharmacol 342, 303-310

Li R, Rezk A, Ghadiri M, Luessi F, Zipp F, Li H, Giacomini PS, Antel J, Bar-Or A (2017): Dimethyl Fumarate Treatment Mediates an Anti-Inflammatory Shift in B Cell Subsets of Patients with Multiple Sclerosis. J Immunol 198, 691-698

Ligocki AJ, Rounds WH, Cameron EM, Harp CT, Frohman EM, Courtney AM, Vernino S, Cowell LG, Greenberg B, Monson NL (2013): Expansion of CD27high plasmablasts in transverse myelitis patients that utilize VH4 and JH6 genes and undergo extensive somatic hypermutation. Genes Immun 14, 291-301

Locksley RM, Killeen N, Lenardo MJ (2001): The TNF and TNF receptor superfamilies: integrating mammalian biology. Cell $\underline{104}, 487-501$ 
Longbrake EE, Cross AH (2016): Effect of Multiple Sclerosis Disease-Modifying Therapies on B Cells and Humoral Immunity. JAMA Neurol 73

Lublin FD, Reingold SC (1996): Defining the clinical course of multiple sclerosis: results of an international survey. National Multiple Sclerosis Society (USA) Advisory Committee on Clinical Trials of New Agents in Multiple Sclerosis. Neurology $\underline{46}$, 907-911

Lucchinetti C, Brück W, Parisi J, Scheithauer B, Rodriguez M, Lassmann H (2000): Heterogeneity of multiple sclerosis lesions: implications for the pathogenesis of demyelination. Ann Neurol 47, 707-717

Maddur MS, Sharma M, Hegde P, Stephen-Victor E, Pulendran B, Kaveri SV, Bayry J (2014): Human B cells induce dendritic cell maturation and favour Th2 polarization by inducing OX-40 ligand. Nat Commun $\underline{5}, 4092$

Malek TR (2008): The biology of interleukin-2. Annu Rev Immunol 므, 453-479

McDonald WI, Compston A, Edan G, Goodkin D, Hartung HP, Lublin FD, McFarland HF, Paty DW, Polman CH, Reingold SC, et al. (2001): Recommended diagnostic criteria for multiple sclerosis: guidelines from the International Panel on the diagnosis of multiple sclerosis. Ann Neurol $\underline{50}, 121-127$

McGinley MP, Moss BP, Cohen JA (2017): Safety of monoclonal antibodies for the treatment of multiple sclerosis. Expert Opin Drug Saf 16, 89-100

McKeage K (2015): Glatiramer Acetate $40 \mathrm{mg} / \mathrm{mL}$ in Relapsing-Remitting Multiple Sclerosis: A Review. CNS Drugs 29, 425-432

Michel L, Touil H, Pikor NB, Gommerman JL, Prat A, Bar-Or A (2015): B Cells in the Multiple Sclerosis Central Nervous System: Trafficking and Contribution to CNSCompartmentalized Inflammation. Front Immunol 6, 636

Miller DH, Barkhof F, Montalban X, Thompson A, Filippi M (2005): Clinically isolated syndromes suggestive of multiple sclerosis, part I: natural history, pathogenesis, diagnosis, and prognosis. Lancet Neurol 4, 281-288

Miller DH, Leary SM (2007): Primary-progressive multiple sclerosis. Lancet Neurol $\underline{6}$, 903 912

Miron VE, Boyd A, Zhao J-W, Yuen TJ, Ruckh JM, Shadrach JL, van Wijngaarden P, Wagers AJ, Williams A, Franklin RJM, Ffrench-Constant C (2013): M2 microglia and macrophages drive oligodendrocyte differentiation during CNS remyelination. Nat Neurosci 16, 1211-1218 
Miyazaki Y, Niino M, Takahashi E, Suzuki M, Mizuno M, Hisahara S, Fukazawa T, Amino I, Nakano F, Nakamura M, et al. (2018): Fingolimod induces BAFF and expands circulating transitional B cells without activating memory B cells and plasma cells in multiple sclerosis. Clin Immunol 187, 95-101

Moll NM, Rietsch AM, Ransohoff AJ, Cossoy MB, Huang D, Eichler FS, Trapp BD, Ransohoff RM (2008): Cortical demyelination in PML and MS: Similarities and differences. Neurology $\underline{70}, 336-343$

Montalban X, Hauser SL, Kappos L, Arnold DL, Bar-Or A, Comi G, de Seze J, Giovannoni G, Hartung H-P, Hemmer B, et al. (2017): Ocrelizumab versus Placebo in Primary Progressive Multiple Sclerosis. N Engl J Med 376, 209-220

Moore KW, de Waal Malefyt R, Coffman RL, O'Garra A (2001): Interleukin-10 and the interleukin-10 receptor. Annu Rev Immunol 19, 683-765

Moreno Torres I, García-Merino A (2017): Anti-CD20 monoclonal antibodies in multiple sclerosis. Expert Rev Neurother 17, 359-371

Nakamura M, Araki M, Yamamura T (2015): [Plasmablast in the pathology of multiple sclerosis]. Nihon Rinsho Meneki Gakkai Kaishi $\underline{38}$, 403-411

Nova-Lamperti E, Fanelli G, Becker PD, Chana P, Elgueta R, Dodd PC, Lord GM, Lombardi G, Hernandez-Fuentes MP (2016): IL-10-produced by human transitional B-cells down-regulates CD86 expression on B-cells leading to inhibition of CD4+Tcell responses. Sci Rep $\underline{6}, 20044$

O'Connor P, Filippi M, Arnason B, Comi G, Cook S, Goodin D, Hartung H-P, Jeffery D, Kappos L, Boateng F, et al. (2009): 250 microg or 500 microg interferon beta-1b versus $20 \mathrm{mg}$ glatiramer acetate in relapsing-remitting multiple sclerosis: a prospective, randomised, multicentre study. Lancet Neurol $\underline{8}, 889-897$

Ontaneda D, Nicholas J, Carraro M, Zhou J, Hou Q, Babb J, Riester K, Mendoza JP, Livingston T, Jhaveri M (2018): Comparative effectiveness of dimethyl fumarate versus fingolimod and teriflunomide among MS patients switching from firstgeneration platform therapies in the US. Mult Scler Relat Disord 27, 101-111

Otero-Romero S, Sastre-Garriga J, Comi G, Hartung H-P, Soelberg Sørensen P, Thompson AJ, Vermersch P, Gold R, Montalban X (2016): Pharmacological management of spasticity in multiple sclerosis: Systematic review and consensus paper. Mult Scler $\underline{22}$, 1386-1396

Papadopoulou A, Derfuss T, Sprenger T (2017): Daclizumab for the treatment of multiple sclerosis. Neurodegener Dis Manag 7, 279-297 
Pardo G, Jones DE (2017): The sequence of disease-modifying therapies in relapsing multiple sclerosis: safety and immunologic considerations. J Neurol 264, 2351-2374

Patrikios P, Stadelmann C, Kutzelnigg A, Rauschka H, Schmidbauer M, Laursen H, Sorensen PS, Brück W, Lucchinetti C, Lassmann H (2006): Remyelination is extensive in a subset of multiple sclerosis patients. Brain J Neurol 129, 3165-3172

Piccio L, Naismith RT, Trinkaus K, Klein RS, Parks BJ, Lyons JA, Cross AH (2010): Changes in $\mathrm{B}$ - and T-lymphocyte and chemokine levels with rituximab treatment in multiple sclerosis. Arch Neurol 67, 707-714

Polfliet MMJ, van de Veerdonk F, Döpp EA, van Kesteren-Hendrikx EML, van Rooijen N, Dijkstra CD, van den Berg TK (2002): The role of perivascular and meningeal macrophages in experimental allergic encephalomyelitis. J Neuroimmunol 122, 1-8

Pöllinger B, Krishnamoorthy G, Berer K, Lassmann H, Bösl MR, Dunn R, Domingues HS, Holz A, Kurschus FC, Wekerle H (2009): Spontaneous relapsing-remitting EAE in the SJL/J mouse: MOG-reactive transgenic $\mathrm{T}$ cells recruit endogenous MOGspecific B cells. J Exp Med 206, 1303-1316

Polman CH, Reingold SC, Edan G, Filippi M, Hartung H-P, Kappos L, Lublin FD, Metz LM, McFarland HF, O'Connor PW, et al. (2005): Diagnostic criteria for multiple sclerosis: 2005 revisions to the „McDonald Criteria“. Ann Neurol 58, 840-846

Polman CH, Reingold SC, Banwell B, Clanet M, Cohen JA, Filippi M, Fujihara K, Havrdova E, Hutchinson M, Kappos L, et al. (2011): Diagnostic criteria for multiple sclerosis: 2010 revisions to the McDonald criteria. Ann Neurol 69, 292-302

Popescu BFG, Pirko I, Lucchinetti CF (2013): Pathology of Multiple Sclerosis: Where Do We Stand? Continuum 19, 901-921

Putheti P (2003): Effect of glatiramer acetate (Copaxone) on CD4+CD25high T regulatory cells and their IL-10 production in multiple sclerosis. J Neuroimmunol 144, 125-131

Qizilbash N, Mendez I, Sanchez-de la Rosa R (2012): Benefit-risk analysis of glatiramer acetate for relapsing-remitting and clinically isolated syndrome multiple sclerosis. Clin Ther $\underline{34}$, 159-176.e5

Raine CS (1994): Multiple sclerosis: immune system molecule expression in the central nervous system. J Neuropathol Exp Neurol $\underline{53}$, 328-337

Rawlings DJ, Metzler G, Wray-Dutra M, Jackson SW (2017): Altered B cell signalling in autoimmunity. Nat Rev Immunol 17, 421-436 
Rieks M, Hoffmann V, Aktas O, Juschka M, Spitzer I, Brune N, Schimrigk S, Przuntek H, Pöhlau D (2003): Induction of apoptosis of CD4+ T cells by immunomodulatory therapy of multiple sclerosis with glatiramer acetate. Eur Neurol $\underline{50}$, 200-206

Rivas JR, Ireland SJ, Chkheidze R, Rounds WH, Lim J, Johnson J, Ramirez DMO, Ligocki AJ, Chen D, Guzman AA, et al. (2017): Peripheral VH4+ plasmablasts demonstrate autoreactive $\mathrm{B}$ cell expansion toward brain antigens in early multiple sclerosis patients. Acta Neuropathol 133, 43-60

Rizzo F, Giacomini E, Mechelli R, Buscarinu MC, Salvetti M, Severa M, Coccia EM (2016): Interferon- $\beta$ therapy specifically reduces pathogenic memory B cells in multiple sclerosis patients by inducing a FAS-mediated apoptosis. Immunol Cell Biol $\underline{94}$, 886894

Rodríguez-Pinto D, Moreno J (2005): B cells can prime naive CD4 ${ }^{+} \mathrm{T}$ cells in vivo in the absence of other professional antigen-presenting cells in a CD154-CD40-dependent manner. Eur J Immunol 35, 1097-1105

Rothaug M, Becker-Pauly C, Rose-John S (2016): The role of interleukin-6 signaling in nervous tissue. Biochim Biophys Acta 1863, 1218-1227

Rovituso D, Heller S, Schroeter M, Kleinschnitz C, Kuerten S (2014): B1 cells are unaffected by immune modulatory treatment in remitting-relapsing multiple sclerosis patients. J Neuroimmunol 272, 86-90

Rovituso DM, Duffy CE, Schroeter M, Kaiser CC, Kleinschnitz C, Bayas A, Elsner R, Kuerten S (2015): The brain antigen-specific B cell response correlates with glatiramer acetate responsiveness in relapsing-remitting multiple sclerosis patients. Sci Rep 5, 14265

Sancho D, Gómez M, Martinez Del Hoyo G, Lamana A, Esplugues E, Lauzurica P, Martinez-A C, Sánchez-Madrid F (2006): CD69 targeting differentially affects the course of collagen-induced arthritis. J Leukoc Biol 무, 1233-1241

Sauer BM, Schmalstieg WF, Howe CL (2013): Axons are injured by antigen-specific CD8(+) T cells through a MHC class I- and granzyme B-dependent mechanism. Neurobiol Dis $\underline{59}, 194-205$

Sean Selva LJJ (2014): B Cell Receptor Recognition of Glatiramer Acetate is Required for Efficacy through Antigen Presentation and Cytokine Production. J Clin Cell Immunol $\underline{05}, 185$

Seidi OA, Sharief MK (2002): The expression of apoptosis-regulatory proteins in B lymphocytes from patients with multiple sclerosis. J Neuroimmunol 130, 202-210 
Sela M, Teitelbaum D (2001): Glatiramer acetate in the treatment of multiple sclerosis. Expert Opin Pharmacother 2, 1149-1165

Sellner J, Koczi W, Harrer A, Oppermann K, Obregon-Castrillo E, Pilz G, Wipfler P, Afazel S, Haschke-Becher E, Trinka E, Kraus J (2013): Glatiramer acetate attenuates the pro-migratory profile of adhesion molecules on various immune cell subsets in multiple sclerosis: Effect of GA on adhesion molecules in MS. Clin Exp Immunol $\underline{173}, 381-389$

Serafini B, Rosicarelli B, Magliozzi R, Stigliano E, Aloisi F (2004): Detection of ectopic Bcell follicles with germinal centers in the meninges of patients with secondary progressive multiple sclerosis. Brain Pathol Zurich Switz 14, 164-174

Shechter R, Miller O, Yovel G, Rosenzweig N, London A, Ruckh J, Kim K-W, Klein E, Kalchenko V, Bendel P, et al. (2013): Recruitment of beneficial M2 macrophages to injured spinal cord is orchestrated by remote brain choroid plexus. Immunity $\underline{38}$, 555-569

Shive CL, Jiang W, Anthony DD, Lederman MM (2015): Soluble CD14 is a nonspecific marker of monocyte activation. AIDS 29, 1263-1265

Sims GP (2005): Identification and characterization of circulating human transitional B cells. Blood 105, 4390-4398

Sims GP, Ettinger R, Shirota Y, Yarboro CH, Illei GG, Lipsky PE (2005): Identification and characterization of circulating human transitional B cells. Blood 105, 4390-4398

Skarica M, Eckstein C, Whartenby KA, Calabresi PA (2011): Novel mechanisms of immune modulation of natalizumab in multiple sclerosis patients. J Neuroimmunol $\underline{235}, 70$ 76

Sospedra M, Martin R (2005): Immunology of multiple sclerosis. Annu Rev Immunol 23 , 683-747

Stadelmann C, Brück W (2004): Lessons from the neuropathology of atypical forms of multiple sclerosis. Neurol Sci 25 Suppl 4, S319-322

Stewart TM, Tran ZV (2012): Injectable multiple sclerosis medications: a patient survey of factors associated with injection-site reactions. Int J MS Care 14, 46-53

Swirski FK, Nahrendorf M, Etzrodt M, Wildgruber M, Cortez-Retamozo V, Panizzi P, Figueiredo J-L, Kohler RH, Chudnovskiy A, Waterman P, et al. (2009): Identification of splenic reservoir monocytes and their deployment to inflammatory sites. Science $\underline{325}, 612-616$ 
Teitelbaum D, Brenner T, Abramsky O, Aharoni R, Sela M, Arnon R (2003): Antibodies to glatiramer acetate do not interfere with its biological functions and therapeutic efficacy. Mult Scler J 9 , 592-599

Thompson AJ, Banwell BL, Barkhof F, Carroll WM, Coetzee T, Comi G, Correale J, Fazekas F, Filippi M, Freedman MS, et al. (2018): Diagnosis of multiple sclerosis: 2017 revisions of the McDonald criteria. Lancet Neurol 17, 162-173

Tornes L, Conway B, Sheremata W (2014): Multiple Sclerosis and the Cerebellum. Neurol Clin $\underline{32}, 957-977$

Tsang BK-T, Macdonell R (2011): Multiple sclerosis- diagnosis, management and prognosis. Aust Fam Physician 40, 948-955

Tsunoda I, Fujinami RS (2002): Inside-Out versus Outside-In models for virus induced demyelination: axonal damage triggering demyelination. Springer Semin Immunopathol 24, 105-125

Tyler AF, Mendoza JP, Firan M, Karandikar NJ (2013): CD8(+) T Cells Are Required For Glatiramer Acetate Therapy in Autoimmune Demyelinating Disease. PloS One $\underline{8}$, e66772

Vazquez BN, Laguna T, Carabana J, Krangel MS, Lauzurica P (2009): CD69 Gene Is Differentially Regulated in T and B Cells by Evolutionarily Conserved PromoterDistal Elements. J Immunol 183, 6513-6521

Veauthier C, Paul F (2016): Therapie der Fatigue bei Multipler Sklerose. Ein

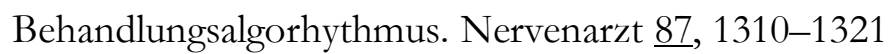

Vermersch P, Trojano M (2016): Tetrahydrocannabinol: Cannabidiol Oromucosal Spray for Multiple Sclerosis-Related Resistant Spasticity in Daily Practice. Eur Neurol 76, 216226

Vieira PL, Heystek HC, Wormmeester J, Wierenga EA, Kapsenberg ML (2003): Glatiramer acetate (copolymer-1, copaxone) promotes Th2 cell development and increased IL10 production through modulation of dendritic cells. J Immunol Baltim $\underline{170}, 4483-$ 4488

Walter S, Doering A, Letiembre M, Liu Y, Hao W, Diem R, Bernreuther C, Glatzel M, Engelhardt B, Fassbender K (2006): The LPS receptor, CD14, in experimental autoimmune encephalomyelitis and multiple sclerosis. Cell Physiol Biochem $\underline{17}, 167-$ 172 
Weber MS, Starck M, Wagenpfeil S, Meinl E, Hohlfeld R, Farina C (2004): Multiple sclerosis: glatiramer acetate inhibits monocyte reactivity in vitro and in vivo. Brain $\underline{127}, 1370$ 1378

Wei S-M, Pan H-L, Wang L, Yin G-L, Zhong K, Zhou Y, Yang S-J, Xin Z-L (2017): Combination therapy with dendritic cell-based vaccine and anti-CD69 antibody enhances antitumor efficacy in renal cell carcinoma-bearing mice. Turk J Med Sci $\underline{47}$, 658-667

Yong VW (2002): Differential mechanisms of action of interferon-beta and glatiramer aetate in MS. Neurology $\underline{59}, 802-808$

Zhang J, Raus J (1994): Myelin basic protein-reactive T cells in multiple sclerosis: pathologic relevance and therapeutic targeting. Cytotechnology $\underline{16}, 181-187$

Zhang Y, Garcia-Ibanez L, Toellner K-M (2016): Regulation of germinal center B-cell differentiation. Immunol Rev $\underline{270}, 8-19$

Ziemssen T, Ashtamker N, Rubinchick S, Knappertz V, Comi G (2017): Long-term safety and tolerability of glatiramer acetate $20 \mathrm{mg} / \mathrm{ml}$ in the treatment of relapsing forms of multiple sclerosis. Expert Opin Drug Saf 16, 247-255

Zingaropoli MA, Iannetta M, Pontecorvo S, Anzivino E, Prezioso C, Rodio DM, Morreale M, D'Abramo A, Oliva A, Lichtner M, et al. (2018): JC Virus-DNA Detection Is Associated with CD8 Effector Accumulation in Peripheral Blood of Patients with Multiple Sclerosis under Natalizumab Treatment, Independently from JC Virus Serostatus. BioMed Res Int 2018, 5297980 


\section{Acknowledgements}

This thesis would not have been possible without a great deal of support from my colleagues, as well as my friends and family.

I would first like to thank my supervisor Prof. Dr. Martin Weber for his great support and expertise. Not only did he offer me all access to the world of research, but he also guided and motivated me tirelessly throughout my entire work on the thesis.

My special thanks go to Dr. rer. nat. Darius Häusler for his patience, motivation and encouragement. The skills and knowledge I gained during my collaboration with him will accompany me throughout my life.

I would like to express my deep gratitude to the technicians of the laboratory of the Neuropathology department for their help and support throughout my research work. 


\section{Curriculum Vitae}

My name is Zivar Hajiyeva. I was born on September 20, 1991, in Baku, Azerbaijan, as the first of two children. My father is an engineer and my mother is a teacher.

In 2008, I graduated from the School N:175 in Baku. At the age of 16, I entered the Azerbaijan Medical University (University entrance examination score 614/700) and studied there until 2010. In 2010, I was awarded an Azerbaijan National Scholarship and was transferred to the Medical Faculty of Istanbul University in Turkey. In 2013, I obtained an Erasmus Mundus Scholarship and was given the opportunity to do my internship at the Humboldt University in Berlin. In 2014, I graduated from Istanbul University and gained my degree of Doctor of Medicine (MD). From December 2014 to May 2016, I worked as a neurology resident at the Martin-Luther University, Halle-Wittenberg. In November 2015, I received a license to practise medicine in Germany. Since July 2017, I have been working at the Department of Neurology at the Georg-August-University of Göttingen as a resident neurologist. I speak Russian, Turkish, Azerbaijani and German fluently and have an excellent command of English. 
$\overline{ }$ 